\title{
Aspects of the haemostatic mechanism in newborns
}

Citation for published version (APA):

Hamulyak, K. (1985). Aspects of the haemostatic mechanism in newborns. [Doctoral Thesis, Maastricht University]. Rijksuniversiteit Limburg. https://doi.org/10.26481/dis.19851220kh

Document status and date:

Published: 01/01/1985

DOI:

10.26481/dis.19851220kh

Document Version:

Publisher's PDF, also known as Version of record

\section{Please check the document version of this publication:}

- A submitted manuscript is the version of the article upon submission and before peer-review. There can be important differences between the submitted version and the official published version of record.

People interested in the research are advised to contact the author for the final version of the publication, or visit the DOI to the publisher's website.

- The final author version and the galley proof are versions of the publication after peer review.

- The final published version features the final layout of the paper including the volume, issue and page numbers.

Link to publication

\footnotetext{
General rights rights.

- You may freely distribute the URL identifying the publication in the public portal. please follow below link for the End User Agreement:

www.umlib.nl/taverne-license

Take down policy

If you believe that this document breaches copyright please contact us at:

repository@maastrichtuniversity.nl

providing details and we will investigate your claim.
}

Copyright and moral rights for the publications made accessible in the public portal are retained by the authors and/or other copyright owners and it is a condition of accessing publications that users recognise and abide by the legal requirements associated with these

- Users may download and print one copy of any publication from the public portal for the purpose of private study or research.

- You may not further distribute the material or use it for any profit-making activity or commercial gain

If the publication is distributed under the terms of Article $25 \mathrm{fa}$ of the Dutch Copyright Act, indicated by the "Taverne" license above, 


\title{
ASPECTS OF THE HAEMOSTATIC MECHANISM IN NEWBORNS
}

\section{Proefschrlft}

tor verkrljging van de graad van doctor in de geneeskunde an de Rilksuniversiteit Limburg te Maastrlcht, op gezag van de Rector Magnlficus, Prof. Dr. F.I.M. Bonke, volgens het beslult van het college van Dekanen in het openbaar te verdedilgen op 20 december 1985 om 16.00 wur

door

\author{
KARLY HAMULYAK \\ geboren to \\ "s-Gravenhage \\ 26 augustus 1948
}


Promator

Copromotor

Referenten
: Prot. Dr. H.C. Hemker

: Dr. C. Vermeer

: Prof. Dr. J.A. Flendrig

: Prof. Dr. E.A. Loelligar

: Prof. Dr. M. Samama
Opgedragen aan

$\mathrm{mIJ} \mathrm{n}$ moeder

ZIJ is, helaas, to vroeg

var ons heengegaan 

Chapter 1

Physlology of the haemostatic mechanlsm in newborns 1

- Intraduction 2

- The haemostatic mechanism in adults 2

- the rolle of the blood platelets 3

- thrombin-platelet interactions . 3

- the formation of thrombin 3

- fibrinogen and factor XIII 6

- inhibltory mechanisms 9

- The haemostatic mechanism in newborns 14

- vessel wall 14

- blood pilatelets 14

- coagulation protelns 15

- coagulation inhibltors 17

- the fibrinalytic system 18

- the prolonged thrombln cllotting time 18

Chapter 2

VItam In $K$ and the newborn 33

- Introduction 34

- Vitamin $K$ deficlency in newborns: possible mechanlsms 35

- How to dlagnose a vitamin K deficlency 37

- The siltuation before, at and after birth 39

- Conclusions and recommendatlons 44

Chapter 3

Flbrin(agen) degradation products in newborn plasmas can cause a false interpretation of the prolongation

of the thrombiatest clotting time

Chapter 4

The synthesis of prothrombin in newborn calves in the first 10 days of 11 fe

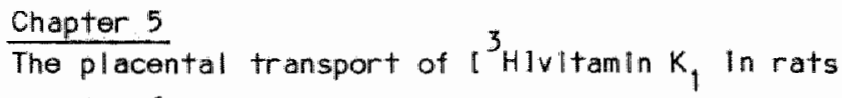

Chapter 6

A new method to assess the amount of vitamin $K$ in

Ilver microsomes

Chapter 7

Reevaluation of some propertles of fibrilnogen,

purifled from cord blood of normal newborns

Chapter B

A new case of a congenital combined

hypo-dys f I br I nogenaem la 
Summary

Samenvatt Ing

133

Nawoord

137

Curr lculum witae

139 
- Introduction

- The haemostatlic mechanlism in adults 1. the role of the blood platelets

2. thrombin-platelet interactions

3. the formation of thrombin

4. flbrinogen and factor XIII

5. Inhibltory mechanlsms

- The haemostatlc mechanlsm in newborns 1. vessel wall

2. blood platelets

3. coagulation protelins

4. coagulation Inhlbitors. serline protease Inhlbitors - Proteln C, Proteln S, APC Inhlbitor

5. the flbrinolytlo system

6. the prolongation of the thrombin clotting time in newborns 
Injury to the wascular endothellum is normally followed by hamostasis, 1.e. The formation of a so called haemostatlic plug. The formation of the haemostatlc plug requires complex interactlons between the vessel wall, blood platelets and number of plasma protelns. Under normal conditlons, these complex interactions are counterbalanced by a number of humoral and cellular protective mechanisms, in order to prevent an excessive reaction, whlch would lead to an Impalred blood flow and the development of thrombosis.

The enzyme thrombin (Factor lla) plays a key role in the formation of the haemostatic plug. Thrombin is formed from prothrombin, in a process katalysed by factor $X a$, that, for all practical purposes, occurs onlly if both factors are bound to a negatively charged phosphollplid surface. This blinding occurs vll extra negat I we charges (gamacarboxyglutamic acld (G|a) residues) which are bulld into the coagulation factors by a vitamin K-dependent mechanism. Thrombin formatlon is regulated by several positive and negative feedback mechanlsms, which will be discussed below.

THE HAEMOSTATIC MECHANISM IN ADULTS

1. The role of the blood platelets

In vascular damage, the blood comes into contact with injured cells and a number of substances present in subendothellal tissue such as collagen, proteoglycans, flbronectin, ellastin and microflbrlils. Blood platelets adhere to these subendothellal structures (1). For a normal adhesion are requlred the von wlllebrand factor complex, platelet membrane receptor protelns and flbronectin (1). The Interaction betwen blood platelets and subendothellal structures activates the blood platelets. Activated blood platelets secrete a number of constituents, among them ADP, calclum and serotonln (from the dense-granules) and a number of platelet speciflic protelns, such as B-thromboglobulin, platelet factor 4 (hepar in neutralizing factory, platelet growth factor and a number of protellns, whlch are also present in plasma, such as von Wlllebrand factor, fibrlnogen, factor $V$, flbronectin and albumin. All these protelns are stored in and can be released from the a-granules (1). Activated platelets produce also the prostanold thromboxane $A_{2}$, whlch is synthesized from its precursor arachldonlc acld, derlwed from the platelet membrane. Thromboxane $A_{2}$ and ACP promote further aggregation and release of surrounding blood platelets. Thromboxane $A_{2}$ and serotonin have also vasoconstrlictory properties (1). simultaneously, the first traces of thrombin are formed wla the activation of factor VII in the presence of tissue thromboplastin leaking from injured cells. (see below) 
2. Thrombin-platelet Interactlons

If acting alone without additional stimull, thrombin, even at a low concentration, wlll cause shape change, aggragation and the release reaction of plattelets. The storage granules release their contents, including factor V. Traces of thrombin convert this factor $V$ Into Its activated form. Apart from thrombin, many other substances can cause release, shape change and aggregation of the platelets. Of all substances (ADP, serotonin, collagen, adrenalin, thromboxane $A_{2}$, platelet activating factor (PAF), etc.), thrombin is the most active one on a molar basls. The concentration at which it shows half maximal activation is 10 to 1000 times lower than that of any other substance lexcept perhaps PAFl. Among the actlvating substances, collagen holds a special position. In suspension, it will activate the platelet. In situations more akin to (patho-) physlaloglcal reallty the platelets stlck to collagen and spread on 1 t, whille belng activated.

A cruclal observation is that thrombin and collagen together wlll cause the outside of the Intact platelet to become an active catalytlc surface for the formation of thrombin (2). To explalln the Importance of this fact, we will first have to elaborate on the molecular blology of the clotting process.

\section{The formation of thrombin}

Clotting factors are proteins that accur in small quantitles in the blood plasma. An exception is factor 1, better known as flbrinogen which is present at 2-4 mg/ml. Factor 11 , present at $0.2 \mathrm{mg} / \mathrm{ml}$, is usually called prothrombin, and the other factors are best known by their roman numeral designation. The vitamin K-dependent factors $11, V I 1, I X$ and $X$ are proenzymes, l.e. they becane proteolytlc enzymes after limited proteolysls Just llke trypsinogen becomes an active protoolytlc enzyme trypsin after limited proteolysis $e . g$. by enterokinase. The activated forms of the clotting factors are Indlicated by the subscrlpt a. Factor VIla activates factor $\| X$ and $X$. Factor $I X a$ activates factor $X$. Factor $X a$ actlivatos prothrombin (factor $\| 1$ ) to produce thrombln (factor Ila). In vascular damage, the bllood comes Into contact with injured cells and with collagen and milcratubules in the connective tissue surrounding the vessel. From the injured cells leaks tissue thromboplastin (TTP), which consists of a phosphollpld part and a proteln part. Tilssue thromboplastin (TTP) forms a complex with the (prolenzyme factor VII, which blinds to phosphollpld surfaces via its gama-carboxyglutanlc acld (Gla) resldues. This complex thus consists of two protelins, one of whlch is a serlne protease, adsorbed together onto a phospholipld. Such a complex is up to 100.000 times more active than factor VIla alone. In fact, the acceleration caused by tlissue thromboplastin is so important that the reaction sequence is started when tissue thromboplastin becomes avallable. In the above, we have referred to both the pro-enzyme factor $V I I$ and the enzyme factor VIlla, whllich must seem Illogical as only factor VIla is the active enzyme. It appears, however. 
that actor VIII is an exception to the general rulle in that It has a non neglectable enzymatlc activity already in its pro-enzyme form. Also the piroduct of the action of factor VIlfa) on factor $X$, 1.e. factor $X a$, activates factor VII so as to form factor VIIa. In addition, the posslbillty exlsts thet factor Vil is acflvated by enzymes from injured cells, by factors from the contact activation system and by other proteolytic enzymes from the plasma.

The flrst small amount of proteolytlic activity is thus easlly obtalned but It wll only lead to full-blown thromblin generation if the subsequent amplifylng mechanisms function properly. If this is not the case, the activity will be rapldly dampened by the antiproteases from the plasma Cantithrombin $111, a_{2}$-macroglobulin, $a_{1}$-antitrypsin etc.). The flrst ampliffying mechanlsm is formed by the reciprocal ectivation of factor Wil by factor Xa. Factor $X a$ is the enzyme responslble for the activation of prothrombln. Just like factor $V / \mid(a)$, factor Xa needs phosphollplids and an extra proteln in order to attain full activity. The phospholipld and the accessory proteln (also called helper proteln or paraenzyme) in this case come from different sources. The accessory proteln is factor va that is formed from $p l a s m a t i c$ factor $V$ or from factor $V$ released by the platelets by the action of thrombin. The phosphollpld can be any negativelly charged phosphollpld, for example, phosphatldylser ine.

TABLE

The enzyme complexes

\begin{tabular}{|c|c|c|c|c|}
\hline & enzyme & accessory factor & substrato & product \\
\hline A & $x a$ & $\mathrm{Va}$ & 11 & thromb in \\
\hline B & $1 X a$ & $v\|l\| a$ & $x$ & $\mathrm{xa}$ \\
\hline $\mathrm{c}$ & $V \| 1(a)$ & TTP & $x, I X$ & $X a, I X a$ \\
\hline
\end{tabular}

Here we have to remark on a blochemllcal fact that is of the utmost Importance in understanding the cooperation between pllatelets and clotting factors in the mechanlsm of haemostasis and the generation of thrombosls: all cell membranes, Including those of the platelet, consist of a bllayer of phosphollplds. This bllayer is asymmetrlcal, l.e. the phosphollpids facling the surrounding medlum have composition that is, in part, different from the layer facing the inslde of the cell.

The strong procoegulant phosphatidyllserine is found entirely or almost entirely in the Inner layer of the cell membrane. That is why intact cells do not show procoagulant activity. The phosphatidylserine present on the Inside becomes avallable to the surrounding medium, only if cells lyse. To 
thils general rule there is one exception: the platelet. Llke all other cells, the intact unactivated platelet has no cor minlmall procoagulant activitles. Recently, however, It has been demonstrated, that a platelet, adherent to collagen and at the same moment exposed to thrombin, wlll present phosphatldylserine on Its outer surface lthout losing its integrlty. Thls is known as the transbllayer phosphollpld transport or "fllp-flop" mechanlsm. Knowling thls, can sumarlze the flrst phase of bllood coagulation as follows:

Tilsue damage exposes the blood to:

a. Tissue thrombop lastin.

b. procoagulant phospholipids from the Interlor of injured cells

c. collagen and microfibrlis from the connectlve tissue.

$a$ and $b$ together cause a small amount of factor $X$ to be activated and, even Iff factor $V a$ is absent, this factor $X a$ can activate some prothrombin in the presence of phosphollpilds. Even very small amounts of thromblin (the equivalent of less than $0.1 \%$ of the prothrombin present in a given volume of blood) wlll cause the platelets that adhere to the exposed collagen to activate thelr "filp-flop" mechanism. Also, they wlll release factor $V$ which is activated by the thrombin present.

The second phase is characterlzed by the raplid formation of thrombin by factor Xa together with factor Va and platelet phospholipids, that in the vicinity of the site of Injury are activated, for example, by ADP, prostanolds and ADP. This platelet aggregate is therefore a potent source of further thrombin formation.

The alternative pathway of activation of factor $X$ by factor IXa we call the paralliel phase of blood coagulation. Factor IXa requires factor VIIla as an accessory proteln and again a procoagulant phosphollipld surface as is provided by stimulated platelets. If $11+t l e$ tissue thromboplastin ils avallable, the formation of factor $X a$ by factor VIla is slow. In this case, the activation of factor IX by factor VIIa, In Itself ten Hlmes slower then the activation of factor $x$, becomes limportant. This is evident if one reallzes that the amount of factor IXa produced by factor Vll la determInes the veloclty of factor $X a$ formation by the parallell pathway. The amount of factor $X a$ thus generated $1 / 11 \mathrm{rlse}$ parabollcally and, In the end, exceed the amount formed directly by factor vila.

If clottling times are long, e.g., In the case of diluted thromboplastins, the levells of factor VIII and IX become Important for thrombin formation. In vivo, this cannot be denied a certain importance, as witnessed by the haemorrhagle tendency of the haemophlllac and by the fact that these patients tend to bleed in thromboplastin-poor tissues like Joints and muscles.

The most important conclusions must be that blood coagulation and platelet reactions are so Interwoven that it makes no sense to try to separate them. Thrombin is the mast important activating agent for platelets and ensures their aggregation to form a stable aggregate. Blood platelets are an 
Indispensible source of phosphollpids and allso supply a part of the necessar $y$ factor $V$.

It $W\|\|$ not have escaped the reader's attention, that have not discussed the contact activation system. This system -Factor Xil (=Hageman factor), Factor Xl, prekall|kreln (PK) and high molecular welght klnimogen (HMwk) Is capable of actlvating factor $1 X$ and factor Vil. It can be triggered by the contact of blood with glass or other negatively charged substances (keolin) or, in wivo e.g. by antlgen-antlbody complexes. Its role in haemostasis and thrombosis is stlll unclear. It is worth noting that the contact activation system not only activates coagulation but allso the flbrinolytic system, the kinIn system and others. Deficlencies in the contact system wll seldam lead to serlous bleeding disorders. Serlous bleedings in factor $X l$ deficlencles do occur but have the character of beling due to overactive fibrinolysls rather then to defliclent clotting cu. Sellighsohn, personal communlcationi. In this context, it is an interesting plece of anecdotlcal evidence that Mr. Hageman (the patient in whom factor XII deflclency was first discovered) died of pulmonary embol $1 \mathrm{sm}$.

Before the activation of factor $I X$ by factor VII la had been discovered, It was thought that onlly factor $X I$ a was capable of activating factor $I X$. Following this Il ne of thought, the contact activation system is compul sory In explaining the role of the antihaemophilic factors (IX and $V\|I\|)$. Thils activation, known as the Intrinsic pathway $(X|1, X|, \mid X, X)$ was regarded as the alternative to the extrinslc pathway, operative in the presence of + Issue thromboplastin $(V \mid I, X)$. We doubt the usefulness of this distinction for In vivo processes, although it may well descrlbe the sltuation in the test tube, where tissue thromboplastin is elther completely absent (partial thromboplastin time) or present in large excesses (prothrombin time). We prefer to use the relnforcement loop of flgure 1 (called the "Josso loap" after the man who first described it) as the basis of a coagulation scheme. To complete this scheme we must include the accessory factors itssue thromboplastin, factor VIII, factor $V$ and the phosphollplds of the platelet membrane.

\section{Flbr Inogen and factor $X 111$}

The flinal event during coagulation is the thrombln-lnduced transformation of the soluble flbrlinogen into flbrin monomers, whlch spontaneously polymerize into an Insolluble network. Factor Xilla then medlates the stabllization of flbrin by crosslinking covalently nelghbouring fibrin monomers. Plasma flbrinogen is a complex, dimerlc glycoprotein with a molecular welght of 340.000 . It is composed of three pairs af homolagous polypeptlide chalns deslgnated $A \alpha, B B$ and $\gamma$, held together by disulphide brldges (3). Carbohydrate is present on the B and Ychains, but its contribution to flarlinogen function is unclear (4). Flbrinogen is requiled for normal Interaction of blood platelets with the vessel wall after injury (5). In vitro, the aggregation of washed human platelets by ADP is also 


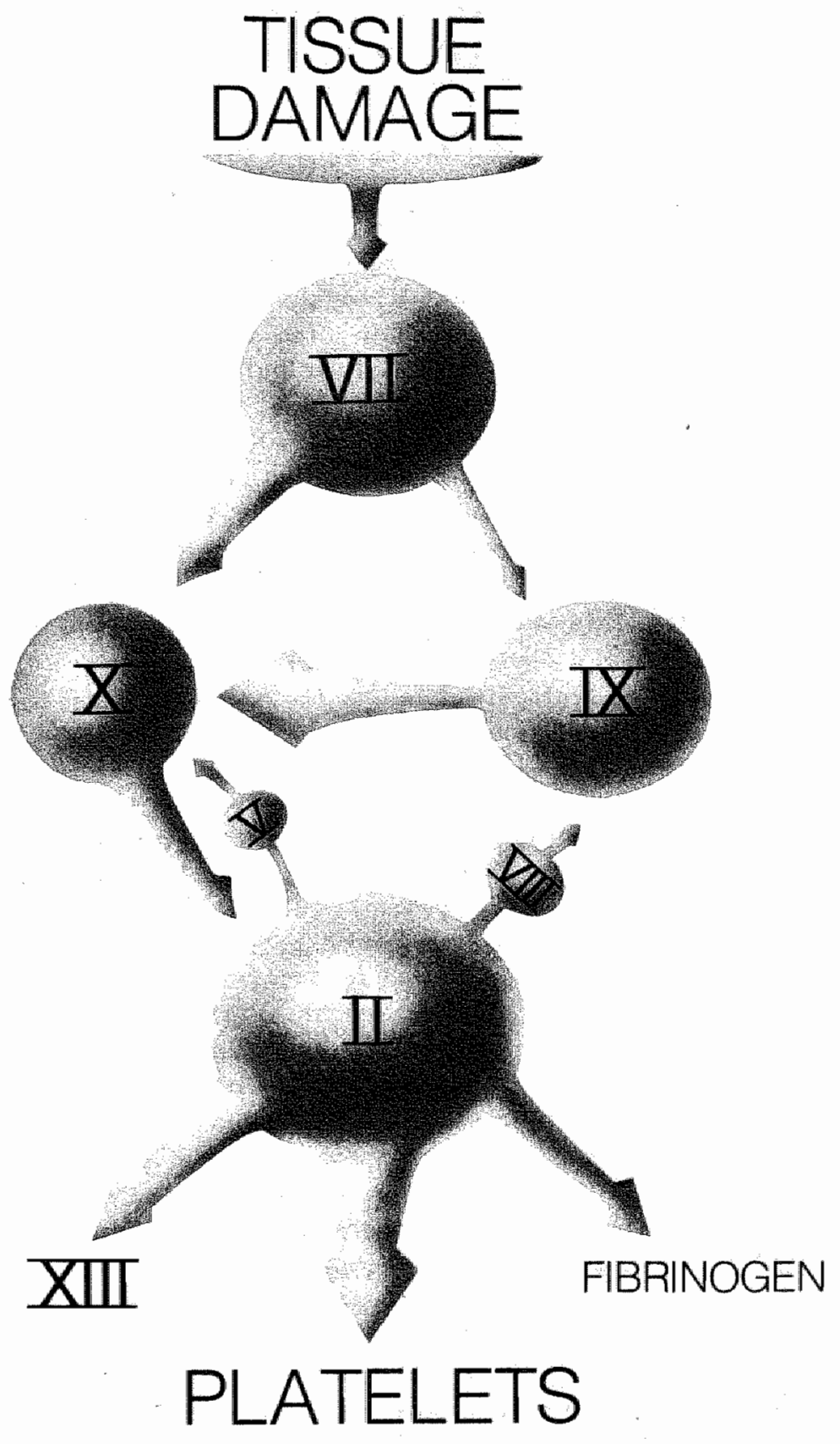

Figure 1: The basis of the coagulation scheme 
dependent on the presence of flbrinogen (5). It has been shown that flbrinogen blnds to speclfic receptors in the platelet membrane. This blinding, requiring divalent lons, occurs in response to the ADP-induced platelet shape change (5). A bindling stte on fibrlnogen, recognized by platelet receptors, is located in the Ychain (5). Flbrinogen Interacts also Wth some ather protelins, notably with flbronectin (5). The binding site for flibronectin appears to be located in the carboxy-terminal portion of the flbrinogen Aa-chain (5). The negatively charged flbrlnopeptides A (16 amilno aclids) and $B$ (14 amino aclds) represent the aminoterminals of the $A \alpha$ and $B B$ chaln, respectively. Thrombln cleaves these fibrlnopeptides off, whlch results in change in charge dlistribution over the molecule and the exposure of two sets of polymerlzation sltes, permitting the polymerlization of flbrin linto flbers and networks (3). The central domain, after the release of the flbrinopeptides, can bind to the terminal domain of unaltered flbrinogen. According to Doolittle's (1981) terminology of "knob and hole" interactions, the knobs generated by removal of fibrlinopeptides. A are able to Interact with the ever present holes on the terminal domain of another molecule. This model allows for growth of a two-molecule-thlck flbrin strand in both directions (6).

Plasma flibrlinogen is syntheslzed in the liver. The $\alpha, B$ and $\gamma$-chains appear to be coded by separate genes. However, the translation of the three genes appears to be coordlnated (7).

The Importance of fibrin crossilnking by activated factor xill became evident when in 1960 the first case of a patlent with a factor Xill deflclency was descrlbed by Duckert (8). This patlent suffered from haemorrhaglc disease and Impaired wound healling. Plasma factor Xlll is a tetramer ic mollecule, composed of two a- and two b-chalns, held together by mon-covalent forces. The molecular welght of the tetramer is 320.000 (9). Activation of plasma factor X/11 proceeds in several steps $(10)$. Thromblin cleaves small activatilon peptlde from the a-chalns. In the presence of calclum the b-chains dissoclate and the actilve cysteln residue becomes exposed. In the absence of flbrinogen unphyslologlcally high calclumconcentrations would be needed, but at normal fibrinogencancentrations, physlologlcal calclumconcentrations are sufflclent. Factor Xlila forms an amIde bond between the $\gamma$-carboxyl group of glutamine and the $\varepsilon-\mathrm{NH}_{2}$ groups of Iystine residues. One consequence of fibrin crosilinking is increased mechanlcal strength of the clot.

Recently, it was shown that $\alpha_{2}$-antlplasmin is also crossilinked to flbrin (11). This explains probably the relative resistance agalnst plasmin digestion of clots formed in plasma. The flbrin $\alpha$-chaln can be crosslinked to fibronectin (12). Flbronectin has been shown to be crossilinked to collagen. This factor Xilla medlated Ilinkage of flbronectin to coll agen could be important for tissue repalr processes (13) and could explain the disturbed wound healling observed in factor XIII deficient patients (14). 
5. Inhlbitory mechanisms

Mechanlsms that $11 \mathrm{mlt}$ and locallize the hamostatic process are er ltllcally Important in order to protect against generallzed thrombosils. In this section the actual view on the following inhibltory mechanlsms will be discussed brlefly:

A Antlcoagulant properties of the vessel wall

B Blood flow and the retliculomendothellal system

C Plasma ser ine protease inhibltors

D Protein, C, Protein S, APC Inhibitor and thrombomodull in

E Feedback Inhibitors

F Fibrinolysis

5A. Antlcoagulant propertles of the vessel wall

The Inner surface of the intact normal vessel wall is non-thrombogenlc. The luminal side of the endothelial cell-line is covered with a negatively charged glycocalix, which prevents adheslon and activation of blood platelets and coagullation factors. Another mechan Ism is the synthesis and release of prostacycilln, a potent vasodilator and inhlbitor of platellet aggregation (15). Prostacyclin is formed from its precursor arachldonic acid via a number of intermediates.

Arachidonic acld is the most abundant fatty acid present in cellular phospholipids. Actlvation of phospholl pase by a varlety of changes in their chemical environment (15) results in the llberation of arachidonlc acid, whlch is further metabollzed by II lpoxygenase and cyclooxygenase. Vascular prostacyclin synthesls occurs princlpally in the endothellum, whereas smooth muscle cells have considerable less prostacycil in synthetase activity. Endothellal cells can be stimulated to release prostacyclin by a varlety of different agents, Including thrombin, trypsin, lonophore A23187, bradykinin, interferon, hlstamine, high density. Ilpoproteins and nitroglycer In $(16,17,18,19,20,21)$. Damus et al (1973) suggested that heparin-1 Ike molecules on the endothellal surface might also contribute to the anticoagulant propertles of the vessel wall (22). It was shown that heparin like molecules could be lliberated from cultured endothellal cells (23) and caplllary endothellum after in situ perfusion (24). In animal models, a heparin-like acceleration of thrombin and factor $X_{a}$ inhlbition by antithrombin 111, prowlded by the endothellum, has been demonstrated (25). That an endogenous heparlin-l ke mechan Ism is also important in humans is Indlcated by the isolation of abnormal antithrombin \|\| molecules, that function normally in the absence of heparin, but not in its presence, from patients with recurrent thrombosis $(26,27)$.

Marcum (28) suggested that heparin-like molecules on the endothellal surface might bind a small fraction of the plasma antithrombin III In viva. That some antithrombln \|\| is Indeed bound to endothellum in $\|$ ffe has been confirmed by Stern 1291. Recently, a new antlcoagulant protein has been descrlbed by Reutellingsperger (30). Thls proteln was Isolated from human 
umblll call cord vessels and bovine aortae. Thls proteln V.A.C. Ivascular anticoagulanty is an Inhibltor of the prothromblnase complex.

Another important contrlbution to the antlcoagulant propertles of the vessel will is provlded by the production of thrombomodulin, whlch acts as an andothellal cell protein cofactor for the thrombin-catalyzed activation of protein $C$. This 111 be discussed bellaw.

Interestingly, thrombin complexed with purlfled thrombomodul in, lases its ability to clot flbrinogen, to activate factor $V$ and to aggregate platelets $(31,32)$. The endothellal cells are also involwed in the flibrinolytlc system by the production and release of plasminogen activator and an inhibltor of this actlvator (see section on flbrinolysis). In the literature a few data are avallable for an active role of the vessel wall in the uptake and degradation of procoagulant substances such as ADP (33) and vasoactive peptlides (34), therefore also contrlbuting to $\mid$ imlting the extent of the haemastatic reaction.

\section{B Blood flow and the retlculo-endothellal system}

It must recognized that, in vivo, coagulation does not occur in the cllosed stirred system generally used to study it in vitro. Blood flaw through the wound area constantly brings fresh factors and platelets and washes away products that then as a rulle are eliminated by the reticulaendothellial system (R.E.S.), especlally in the liver. The liver has the capacity to remove selectlvely actlvated clattling factors from plasma, ithout altering the concentration of the unactivated specles (35).

The fact that most of the coagulatlon reactions occur at Ilpld interfaces tends to locallze the site of the reactions. Other reactions, such as the thrombin-thrombomodulin-proteln C interactions are lacallzed at the endothellum surface near the wound. The actual flow conditions seem to be limportant in the generation of thrombosis. Their effect on haemostasls is as yet I moonpletely understood.

A fact to be reckoned with is that the high pressure gradients caused by the cutting of a vessel induce sudden increases of plasma flow velocity that tend to actlvate platelots by shear stress.

\section{C Plasma ser lne protease Inhlbltors}

Several plasma protease Inhlbltors have been shown to Inhlbit the activity of activated coagulation enzymes: antithrombin \|\| (AT $\| 11), C|-| n h|b| t o r$ $(C I-\ln h), \alpha_{1}$-antltrypsin $\left(\alpha_{1}-A T\right), \alpha_{2}$-antiplasmin $\left(\alpha_{2}-A P\right), \alpha_{2}$-macroglobulin $\left(a_{2}-M\right)$ and heparin cofactor 11 ( 1 C 11$)$. Most inhlbltors are able to neutral ize several different proteases in vitro.

-Antithrombin 111 is a single chain glycoprotein (MW 58.000) with a normal plasma concentration of $100-150 \mu \mathrm{g} / \mathrm{ml}$ (36). AT 111 is consldered to be the main physlologlical Inhlbltor of thrombin and factor $X a$ (37), plasma kall1kroin (38) and plasmin (39) in purl fled systems. Heparin greatly enhances the reaction rate of the enzyme-AT $1 \| 1$ interactlon. Heparin blnds to AT III 
ta short speclfic sequence of sulphated and non sulphated monosaccharlde unlts) wthout changing the stolchlometry of the AT 111 -enzyme complex. Thls results in a conformational change of the inhlbitor resulting in the acceleration of the Inhlbitory effect $(40,41)$.

Hepar In can dissoclate from the complex and be reused in the reaction (42). It has been found that high affinlty, low molecular welght heparin fractions have a relativelly greater antifactor-Xa than anti-lla effect, whereas high molecular welght fractlons have a relatively higher ant thrombin ( 1 la) than antifactor $x a$ activity (43). The physlologlcal importance of antithrombin $\| 11$ is underllined by the tendency to recurrent venous thromboembolic disease in AT 111 deficlent patlents and in patients with abnormal antithrombin 111 moleculles.

-Cl-Inhibitor is a single challn plasma glycoprotein (MW 105.000) contalning a hlgh proportion of carbohydrate (35\%) (44). Desplte the obvlous importance of this inhibitor as a ragulator of the contact activation phase, the congenital deflclency state (hereditary angloneurotic aedena) is not assoclated with any thrombotic or haemostatic disorder (25).

-a-Antitrypsin is a single-chain glycoproteln (MW 55.000) with a relatively high plasma concentration $2.5 \mathrm{mg} / \mathrm{m} \|(45 \%$. It Inhlbits thrombin silow in vitro but does not contrlbute any sigmiflcant part to the overall antithrombin activity of whole plasma (46). It contrlbutes to $70 \%$ of the overall anti factor Xla activity in plasma (47). $\alpha_{1}$-Antitryps in appears not to be an Important regulator of the coagulation system.

$-\alpha_{2}$-Antiplasmin is a single chain glycoprotein (MW 70.000). The reaction rate between plasmin and $\alpha_{2}-A P$ is one of the fastest described for protelnprotein interactions (48). It also inhlblts $\beta$-factor XIla, plasmaka\|likrein, factor XIa and thrombln (49) and factor Xa (50). The contrlbution of $\alpha_{2}$-AP to the overall inhlbitory effect of plasma against these enzymes, seems to be of minor Importance. A hereditary deflalency of this inhlbitor Is assoclated with a severe bleeding tendency $(80)$.

- a, -Macroglobullin is a very large, tetramerle glycoprotein (MW 725.000) (51). $\alpha_{2} M$ has a ide spectrum of protease Inhibitory potential, not Ilimited to serline proteases (52). Among the coagulation proteasts, only thrombin and plasma kallikreln have been demonstrated to the lnhiblted by $\alpha_{2} M$ in vitro. $\alpha_{2} M$ contributed 35-50\% to the overall antlkallikrell activity of plasma (53) and $25 \%$ of the overall plasma ant Ithromblon actlvity (54). - Heparin cofactor $\| 1$ is a new hepar in dependent glycoprotein, that recently has been isolated from human plasma (55). HC 1.l-thrombin interaction is accelerated nearly 1000 times in the presence of high hepar in concentratlons (55). These hepar In concentrations are much hlgher than those usually adminlstered to patlents on heparin treatment for thromboembollc disease. The inhibition of $X a$, however, was reported not to be accelerated by heparin. It also has been reported, that another mucopolysaccharlde, dermatan sulphate, strongly accelerates the Inhibition of thrombln by HC 11 but not by AT 111 (56). The in-VIvo importance of HC 11 remalns to be 
establlshed. Untll now, heredltary HC 11 deflclency is not reported to be unconditionally assoclated ith thrombotlc disease. In a few case reports a possible relation as suggested $(57,58)$.

50 Proteln $C$, Proteln s and activated proteln $C$ inhlbitor (APC inhlbitor)

The endogenous anitleoagulant system involving the witamin K-dependent protelins proteln $C$ (PC) and proteln $S$ (PS) has recentlly attracted much attention due to the discovery of a thrombotlc tendency in patlents with a $P C$ defliclency $(59,60)$ and $P S$ deficlency $(61,62)$.

PC is a vitamin K-dependent serine protease zymogen (MW 62.000, normal plasme concentration $4 \mu \mathrm{g} / \mathrm{m} / \mathrm{l}$. PC must be activated to become an antlcoagulant. Thrombin, the only known physlologlcal activator removes a 12 residue peptide from the amino terminal end of the heavy chaln, leaving the gla-contalning Ilght chain unaffected (63). The in vitro activation of PC to actl waterd protein C (APC) by thrombin was shown to be dramatlcally increased when thrombin and PC were perfused through the microcirculation of the isolated rabbit heart (64). This led to the discovery and isollation of an endothellial cell protein cofactor: thrombomodullin (64). The onhancing effect requlred the presence of calcium. In addition human factor $V a$ and $V a$ light chain accelerate PG activation by thrombin without the need of calclum (65). Thrombomodulin is at least 20 times more efficlent than human factor Va light chall (66).

It has been hypothesized that factor Va and thrombomodulin might synerglstically enhance APC generation.

APC exerts lits antllcoagulant properties by proteolytically destroying factor $V$ and factor VIII coagulant activities (67). The thromb in activated cofactors $\mathrm{Va}$ and Villa are destroyed more rapldly than the native pro cofactors. The degradation is greatly accellerated by phospholliplds and calclum.

Another anticoagulant property of APC is its proflibrinolytic activity, which is medlated vla the Inhlbition of HIssue plasminogen activator (tPA) inhlbitor (68). Another vitamin $K$-dependent proteln, protein $S$ (PS) functions as cofactor in the Inactivation of factor $V a$, (69) and factor VIII and VIII (70). PS Is eble to bind calclum and in the presence of calclum it binds to phosphollplds with higher affinity than other vitamin K-dependent protelins (71).

The APC Induced prolongation of plasma clotting times is nearly abolished when plasma has been depleted of PS and can be restored by the addltion of PS to plasma (69). It has been hypotheslzed that PS exerts an additional role in controlling complement activation (72). Thrombin cleavage of pS causes loss of the cofactor activity for the APC induced factor Va inactivation (73). It is unknown, if this reflects an in vivo regulatory mechanlsm. APC Inhlbitor has been purlfiled by Suzukl (74), a single chain glycoprotelin (MW 57.000, normal plasme concentration approximately 5 $\mu \mathrm{g} / \mathrm{m} \|)$. Assessment of the clinical signiflicance of this inhibltor will await detection of deficient patlents. 
5 E Feadback Inhlbitors.

Thrombin generation also acts to abort the coagullation sequence. The effect of thrombin on factor $V$ and VIII is blphaslc. Initlally cleavage by thrombln, increases the activity of factors $v$ and vill. Continued proteolysis by thrombin destroys the activity of factor $V$ and $V I 11$, so that they can no longer particlpate in thrombin formation. Thrombin is also able to cleave prothrombin fragment 1 from prothrombin, thus generating prethrombin 1 , which lacks the gla-region and does not bind to phosphollplds. The hypothesis that thrombin may regulate its own formation via this negative feed-back, has been questlioned, because no correspondling fragments were found after blood clotting in vitro (75). Another feedback mechanism has been postulated by Rosenberg (36). Flibrinogen polymerlzation is inhiblted when plasmin cleaves the $B B$ chain at position $42-43$ after thrombln-induced release of the fibrinopeptides $A$. Via this mechanlsm plasmin could serve as an anticoagulant besides its role in degrading flbrin.

\section{F The fibrinolytic system}

Coincldent with the formation of a flbrin clot, an enzymatlc system is initiated to remodel or remove the clot and restore the blood flow in the damaged vessel wall. Fibrinolysis is mediated by the enzyme plasmin (76) which is a relatively non-speclfic endopeptidase. It cleaves a varlety of protelns such as fibrin(ogen), factor $V$ and $V I I I$, complement components, $\mathrm{ACTH}$ and growth hormone. Each of these protelns contalns suspectlble arginine and Iysine bonds (76). Plasmin clrculates in its inactive form plasminogen, whlch has a hligh blinding affinity for flbrin as it polymerlzes to form a clot.

Plasminogen can be actlvated to form plasmin by several plasminogen activators: the so called Intrinslc activators (present in the clrculating blood) and extrinslc activators (present in endothellal cells and in other tissues). In pllasma a protein is present with affinity for the Iysinebinding sites in plasmlnogen. Theoretlically thls "hlstidine-rich glycoprotein" may serve as an antlfibrinolytic agent (77). The extrinslc activators can be released upon a varlety of stimull, especlally the tissue type plasminogenactivator (TPA) derlved from the endothellal cell binds strongly to flbrin, rendering it very active in the formation of plasmin from flbrin bound plasminogen. In endothellal cells also an inhlbitor of tPA is synthesized (78). This inhibltor is probably also synthesized by human hepatocytes (79).

To protect the general circulation from effects of plasmin, plasinin I lberated from the dissolving clot is rapidly neutrallzed by an Inhlbitor present in plasma, $\alpha_{2}$-antiplasmin (48). A hereditary deficlency of this inhlbitor is assoclated with a severe bleeding tendency (BO).

A number of excellent reviews on the fibrinolytic system have been publlshed. As a more detalled revlew of this system is beyond the scope of this thesls we refer the reader to collen (76), Francls (81), Aoki (B2), Bachmann (83) and Brommer (B4). 
Several key aspects of the hamostatlc mechanlim in newborns are defective whon compared to adult standards (85). Quantitative as well as qualitative differences have been descrlbed. Tremendous varlations occur in many of the components of the haemostatlc mechanlism, making the newborn infant prone to both haemorrhage and thrombosis (86). Most of the information currently avallable is based upon functional assays rather than blochemical or physlochemical technlques. In the following section the current data on the varlous components of the haemostatic mechanism in newborns are sumarlzed.

\section{Vessel wall}

Small preterm newborns may brulse excessively after minimal trauma. Thelr predisposition to serlous Intraventrlcular haemorrhage has been in part explained by inadequate connective tissue support of capll larles and small venules (87). However, no hard data are avallable to support the clinlcal Impression that the so callied "vascular fragllity" is indeed Increased in these infants (88). The methodology of evaluating the in vivo vessel wall function is impreclse and poorly standardized. According to Buchanan (88) the vessel wall function in normal full term newborns is comparable with that of adults.

In the last decade, our knowledge of the propertles of the vessel wall has raplaly grown, since it has become possible to culture endothellal cells (89). Many data In man, have been obtalned by using endothellal cell cultures derlved from umbllical veins. It remalns to be established whether these data can be extrapolated to the adult siltuation.

2. Blood platelets

Platelets have been Identifled in fetuses of greater than 11 weeks gestation (90). Healthy newborn infants, even the smallest premature bables have platelet counts in the same 5 ange as normal adults. Therefore, a platelet count of less than $150 \times 10^{9} / 1$ indlcates thrombocytopenla, regardless of the gestatlonal age (91). There is some evidence that nowborns have a mild translent defect in platelet function. A number of investigators have reported a diminlshed secondary aggregation to eplnephirine, llow molecular AOP, dlluted collagen and thrombln, suggesting an impalred release of endogenous ADP $(92,93)$. The defective aggregatlon to epinephrine and coll agen is aggravated by maternal aspirln ingestion (93). The mechanlsm is unknown, although studles have suggested a defect in release and stores of metabollc ADP (94) and in release of serotonin (95). Electronmicroscopic studies indlcate that neonatal platelets are normal and thus have dense bodles, those organelles which contain non metaboll $\mathrm{ADP}$ (96). The studles of Stuart (97) and Del Princlipe (98) have shown that the noonatal prostaglandin synthetlo pathway is probably intact (possibly sll lghtly Impaired) on stimulation with thrombin. Corby (s9) showed that 
arachlidonlc acld induced aggregation of neonatal platelets is normal. It was concluded that the cyclooxygenase pathway is normal. By several of age normal platelet aggregation is found $(100)$. It has been postulated that hypoxla plays an aetlological role in the translent platelet function defect of newborns (88).

Platelet adheslveness to glass is normal and clot retraction decreased (92, 101). The response of neonatal platelet to rlstocetin is normal (96). Several groups of Investigators $(97,102)$ have demonstrated that the bleeding time is not prolonged in newborn infants. This test is considered to be the most important clinical test of platelet function $\$ 103$ ).

\section{Coagulation protelns}

a. Contact factors: XII, XI, prekallikreln, high molecular welght (HMW) kin Inogen *

The contact factors are reduced in normal newborns, with their range belng between 20-30\% in preterm infants and 20-50\% in term infants $(104,105,106,107)$. Except for factor $x_{1}$ deficlency, a deficlency in the contact factors has not been assoclated with signiflcant. hamorrhage in adults. The deficlency of the contact factors in newborns may at least in part explain the extremely long partlall thromboplastin time (PTT) frequently seen in normal term and preterm infants (108). In general, a deficiency of the contact clotting factors results in a much longer PTT than a corresponding deflciency of factor VIII or factor IX (91). Different reagents used for the PTT cause normal ranges to vary greatly from one laboratory to another. The sensitivity and normal ranges must therefore be speclfically defined in the Individual laboratory* According to Montgomery (91) the expected normal range for normal term Infants in their laboratory is 55-75 seconds (range in adults 36-51 sec). In our laboratory the normal range for normal term Infants is 38-70 sec. (adults: $28-40)$.

b. Factor $V$ and Factor VIII

Factor $W$ activity levels in all newborn Infants are comparable with adults $(109,104)$. Even in extremely premature infants (28 weeks) a mean level of 65\% (43-80) has been descrlibed (Barnard 104). Also the factor VIII levels appear to be in the normal adult range in most studies. The data are summarlzed in table 2 for normal terin infants.

TABLE II

$\begin{array}{lll}\text { factor VIII procoagulant actIvIty } & 125-168 \% & (110,104) \\ \text { factor VIII coagulant antligen } & 25-65 \% & (111) \\ \text { factor VIII related antIgen } & 22-200 \% & (104,112,113,114) \\ \text { factor VIII ristocetin cofactor } & 55-140 \% & (112,114)\end{array}$

activity 
It Is Important to reallze that most of the studles have been performed with cord blood speclmens. Dellvery Itself is assoclated with profound physlologlcal alterations, as may be lllustrated by the study of Johnson (115) who found 30-50\% higher values of factor vill-von willebrand factor complex in vaglnally dellyered Infants, compared to Infants dell vered by Caesarean sectlon.

Fukul (114) suggested qualltative abnormallties of newborns factor VIII based on crossed Immunoelectrophoretic studies. This alteration could not be confirmed by other authors $(115)$.

c. The vitam In K-dependent coagulation factors: $11, V 11,1 X, X$ * The vitamin $K$-dependent pracoagullants ( $F\|, F V\|, F \| X$ and $F X$ ) are reduced In both term and preterm Infant. $(196,117,109,104)$. Mast studles have been performed using clotting activity assays. These studles show a gestational age dependency. The concentration increases from about $30 \%$ at 24 weaks to about $50 \%$ of adult normal values at term. Immunologlcal studies of prothrombin (F HI) indlcate, that no differences exist betwen newborn and adult prothrombin. In some cases, however, changes assoclated with a vitamln $K$ deflclency have been described (118). These observations have been refuted by ather groups $(119,120)$. The "witamin $k$ problem" in newborns is extenslvelly discussed in chapter 2 of this thesisi:

d. Fibrinogen (Factor I) and fibrin-stablilzing factor (Factor $X \| 11$ )

Quantltative studles of flbrinogen in term infants indicate that the levels are in the normal adult range (108). The mean wallues range from $1.9-2.6 \mathrm{gr} / 1$. Aguerclf (121) found slightly lower values using clot denslity or thrombin clotting methods than using colorimetrlc, heat precipltation or bluretmethods. A number of investigators have suggested the possibllity of a distinct tetal flbrinogen, whlch might explain the prolonged thrombin and reptllase clotting times found in all newborns, In the absence of fibrin(ogen) degradation products. In chapter 7 of thls thesls wave reevaluated thls so called fetal flbrlinogen. We have concluded that most of the differences reported in the llterature to be dwe to a distinct fetal flibrlinogen, cannot be confirmed, provlded that optlinal care is taken to minimize proteolytlc breakdown in vitro. The only remarkable difference is the observation that the phosphate content is 3-4 fold higher in cord flbr lnogen than in adult flbirnogen. Most of the phosphorus in fibrinogen is located in the part of the molecule where the flbrinopeptides are splitt off. Until now the function of phosphorus in flbrinogen is uncllear. In one study (122) dephosphorylation of "fetal flbrlnogen" appeared to have no influence on its clotting propertles. Some authors have suggested that in cord blood a mixture of adult and "fetal fibrinogen" is present, and that in premature infants relatively more "fetal flbrlnogen" is present (123). The different clotting propertles of "fetal fibrinogen" have also been ascribed to a higher slallc acid content and it has been postulated that 
enzymatic removal of slalic acid corrected the abnormal findings (127). In our study we found the same carbohydrate content in as well adult as cord flbrinogen. Factor X $X \mid 1$ levels in normal term infants are approxlmately $50 \%$ of the values found in normal adults $(124)$.

4. Coagulation Inhibitors

a. Serine protease \|nhibitors: Antithrombin $\|1\|$ and $\alpha_{2}$-macroglobullin Antithrombin 111 levels in newborn infants are also reduced compared with adult values, irrespective of the method used (108). Levels range from 40-87\% in normal term infants by Immunological measurements, from 45-60\% by clotting activity methods and from 11-104 (mean 65\%) by chromogenic substrate method. The antithrombin 111 levels are also dependent on the gestatlanal age $(126,109,127)$. McDonald (1982) found in a blachemlcal and functional study of antithrombln 111 no differences between adult and newborn antithrombln 111 (128). In a recent report (129) a reduced actlvity/antigen ratio of antithrombin 111 in newborns (range 0.26-0.86) was descrlbed. This discrepancy present in $90 \%$ of all samples and Independent of the state of health. It could not be attributed to laboratory artefacts, clrculating antithrombin 111 thromb in complexes or by Increased heparin cofactor II plasma levels in neonates. The posslblilty of an abnormal newborn antithrombln $\| 11$ molecule with decreased heparin affinity was postulated, but not substantiated. Al though $50 \%$ reductions in ant ithrombin 111 have been assoclated with major thrombotllc tendencles in adults, it is of interest, to note that newborn antithrombin 111 levels are in the same range as the $v i t a m i n k$ dependent coagulation factors. This might explain in part why In normal healthy term newborns thrombosis is rare. The levels of $\alpha_{2}$-macroglobulin are normal in normal term infants compared with adult values $(130,131)$ or even Increased to around $150 \%$ (119). $\alpha_{2}$-macroglobulin complexes with serline proteases and relles upon reticuloendothellal clearance rather than inactivation (132). Its physlologlcal role may therefore be reduced because of the newborns reduced reticulo endothelial function (91). In adults antithromblin 111 contr lbutes to 60-70\%, $\alpha_{2}$-macroglobull $20-30 \%$ of the total antlthrombln capaclty. Thls has not been Investigated for newborns.

b. Protelin C, Protein S and APC Inhlbitor

In normal term infants protein C levels are 18-46\% of adult values (Marlar 1984, unpubllished data, clted in Montgomery $(91)(133,134)$. Protelin S levels were 7-40\% (91) and APC Inhlibltor 65-96\% (91). Since the role of both protein $C$ and $S$ is to Inactivate factors $V$ and $V I I I, a$ deficlency of protein $C$ results in a thrombotic tendency (135). Factor $V$ and VIII are both at normal (adult) values in newborns.

The physlological imbalance between proteln $C$ and factors $V$ and $V I I I$ is therefore a theoretical cause for a thrombotlc tendency. Recurrent thrombotic problems or purpura fulminans in the neonatal perlod, how- 
ever, have onlly been found in cases of a homozygous protein $C$ defliclency $(136,137,138)$. On the other hand, these problens should prompt the cliniclan to conslder this dlagnostic possibllity because without appropr late therapy homozygous protein $C$ deflclency is probably incompatible with life. It is of interest, to note that for unknown reasons these infants do not die in utero (91).

\section{The flibel inelytlic system}

Most studies suggest an overall lncrease in fibrinalytic activity in newborns (109), In splite of the fact that plasminogen is reduced to $50 \%$ of normal adult values and that $a_{2}$-antiplasmin antigen is in the normal adult range $(105)$. The increased fibrinolytic activity may theoretically be due to Increased plasmlnogen actlvator levels and/or reduced levels of plasml nogen actlvator inhlbitors.

Recently, no studles have been published on this subject in newborns. Beller found In 1966 Increased actlvator activity in cord blood (139), Ekelund (139) found normal values. Our knowledge of the flbrinolytic system in newborns is therefore $11 \mathrm{mited}$. However, it is important to note that infants stressed with respliratory distrass syndrome (RDS) or disseminated Intravascular coagulation (DIC) qulckly deplete their flibrinolytic potential (140), thereby loosing one of the physlolaglcal defense mechanisms agalnst the development of $(m / \mathrm{cro})$ thrombosis.

6. The prolongation of the thromblin clotting time in newborns

The role of thrombin in the formation of a stabllized fibrin gel is summarlzed in figure 2. Thrombin cleaves the negatively charged fIbrlnopeptIdes A and B (FPA and FPB) from the amino-terminal positions of the $\alpha$ and $B$ chalns. The resulting change in charge distribution over the molecule, now called flbrin monomer and the exposure of two sets of polymerlization sites permit the polymerlzation of fibrin into flbers and networks (141). A final modiflcation to ensure the stabllity of the flbrimclat is provided by the activation by thrombln of factor XIII. Thls factor catalyzes the formation of Irreversible covalent bonds between glutamls acld and Iysine resldues on adjacent flbrin monomers (142), the so called cross linkling. Thls is shown in flgure 2 .

A prolonged thrombin clotting time in plasma is found in quantitative and qualltative abnormalitles of flbrinogen and when inhlbitors are present of thrombin, of fibrin monomer polymerization and of fibringel cross linking. Thromb in clotting tlmes are measured by adding $50 \mu 1$ of a thrombin solution of $5-10 \mathrm{~N} . \mathrm{l} . \mathrm{H} . \mathrm{U} / \mathrm{ml}$ to $0.2 \mathrm{ml}$ platelet free plasma after $30^{\prime \prime}$ Incubation of the plasma at $37^{\circ} \mathrm{C} .1$ it is a well known observation that the thrombin clotting time in all normal term newborns is prolonged. This observation could not be attributed to quantitative and or qualitative alterations of flbrinogen. (chapter 7 of thls thesis) or 


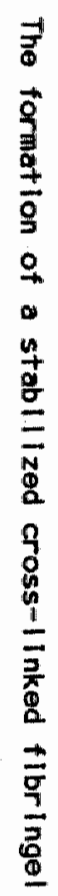

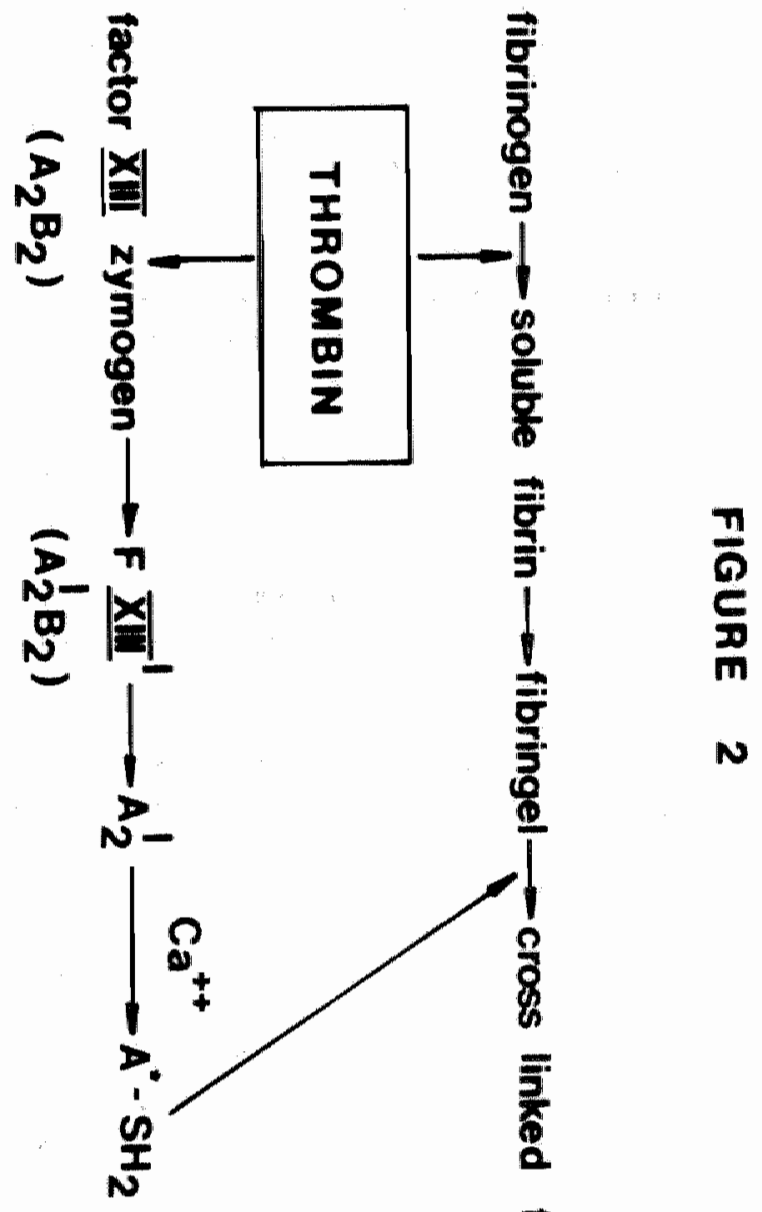

$\frac{9}{8}$ 
harge anounts of flbrin(ogen) degradation products.

Using the conventlonal assay (Wellcome) we found in none of the samples more than $10 \mathrm{mg} / 1$ FDP's, however, it can not be excluded that smaller amounts contribute to the prolonglation of the thrombin clotiling time in newborns. In chapter 3 of this thesls we descr lbe the presence of small amounts of flibrin- and flbrlinogen degradation products in a number of cord plasmas, in which Inhibitory materlal was present as judiged from thrombotest dilution curves.

In a very few cases, a remarkable prolongation of the thrombin clotting time was found. In 2 out of 200 samples the thromb in clotting time was langer than 5 minutes (normal range cord plasma: $23-46^{\text {*t)}}$ ). These samples were obtalned from infants, who differed in no way from the other Investigated newborns. In these samplles we found an alternative explanation for the prolonged thrombin clotting time, suggesting a heparln-like substance. In flgure 3 the curves are shown of a two stage prothrombin assay of adult and cord plasma. In these curves the formation of thrombln in plasme and its disappearance due to antithrombin activity present in plasma is shown. They were performed as described by Hemker et al (143). From this figure it can be seen that there are only slight differences between adult and newborn plasma. However, in the 2 newborn samples with a remarkable prolonged thrombin clotting $\#$ ime, the thrombin generation curve was markedly different so that thromb in was not any longer demonstrable already after 5 minutes. These 2 newnborn samples were further investigated. The thrombin inhibitory effect could be reduced by adding calclum and protamine chlorlde to the plasma. Because of the limited quantity of these plasma it has not been possible to purify and characterlze thls Inhlbltor. Therefore, we have been unable to check the data obtained as thoroughly as we would Ilke to. All flibr Inogen related materlal was removed using a ristocetin-sepharose column. In the luate the Inhlbltor was present and could be adsorbed to a protamine-sepharose column. The inhibltor was eluted from this column using sodlumchlorlde gradlent. Thls luate was extensively dialyzed against buffer $(0.15 \mathrm{M} \mathrm{NaCl}, 10 \mathrm{mM} \mathrm{Trls-HCl,} \mathrm{pH} 7.4)$. The Inhlbitory effect was measured by Incubating of the Inhlbitory sample with normal adult plasma and measurling a thrombin clotting time. The Inhibition was abollshed by adding protamine chlorlde and upon Incubation with heparinase, (from cuitures of the flavobacterlum hepar inum), whilch was kindly provlded by Dr. Rosenberg. The inhlbition could not be abolished upon Incubation wth trypsin. The inhibitory effect appeared to be dependent on the presence of antithrombin 111. In the following experlments. ant Ithrombin 111 (Kabl Vitrum, Amsterdam, the Netherlands) (f.c. $1 \mathrm{U} / \mathrm{m} l$ ) was added. The effect of the inhibitor on the amidolytic activity of thrombin and factor $X a$ was measured in a Beckman spectrofotometer, using the chromogenlc substrates $\$ 2238$ and $\$ 2337$. As a reference, comerclal hepar In (thrombollqulne, Roche, Basle, Swltzerland) was used (1 


\section{FIGURE 3}

\section{TWO STAGE PROTHROMBIN ASSAY}

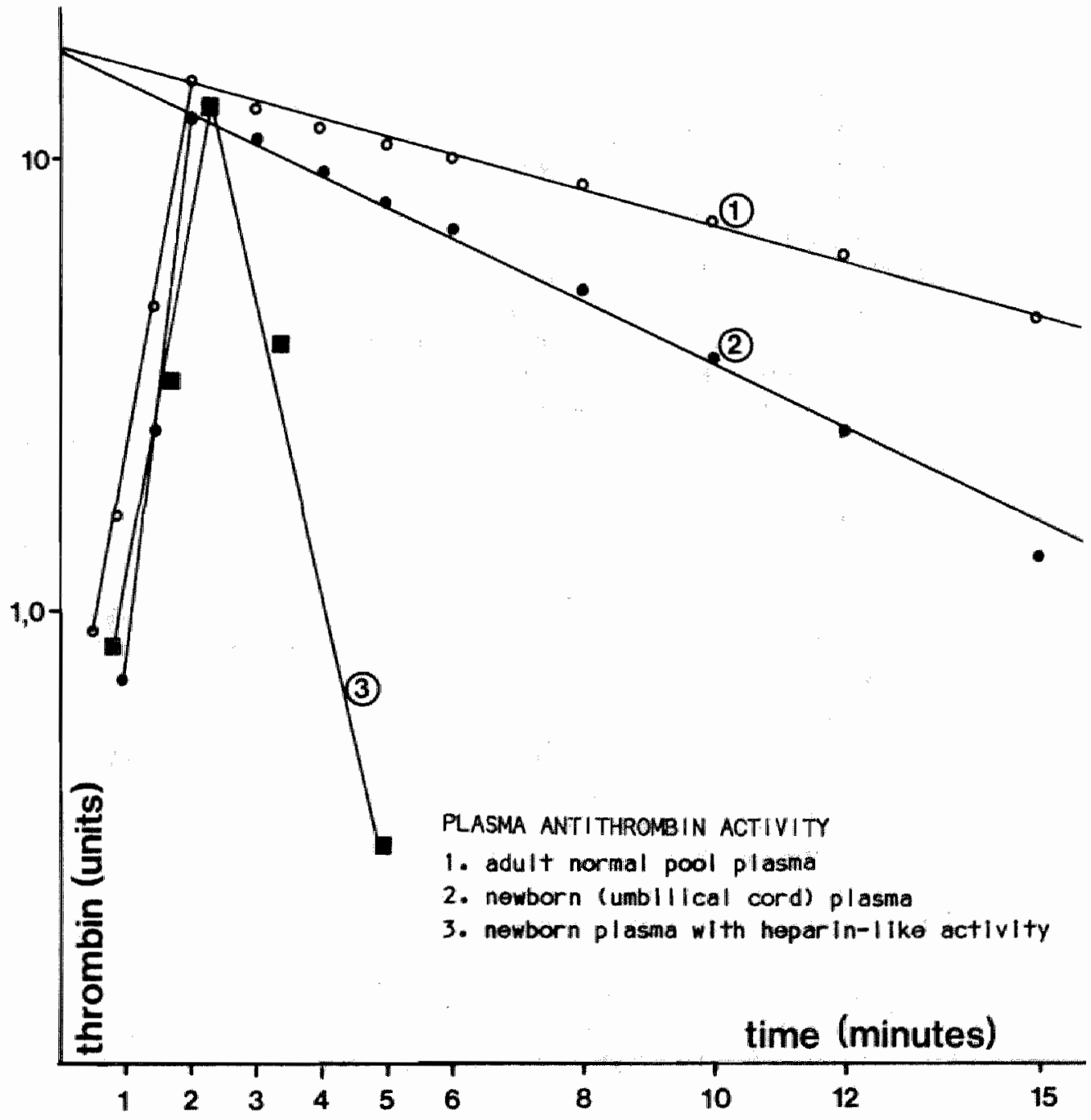


1.U./mis. The inhlbitor from newborn plasma had no effect on the amldolytic acltivlty of factor $X a$ (f.c. $20 \mathrm{nM}$, however, a remarkable effect of the activity of thrombin (f.c. $0.1 \mathrm{~N} .1 . H . U . / \mathrm{ml})$. The reference commerclal heparin showed a complete inhlbition of factor $x a$ in concentrations hich gave less inhibition of thrombln than the newborn inhlibltor. The above mentioned experlments suggest that in a few cases (1\%) of normal term Intants heparin-llke activity can be demonstrated wth a remarkable antll lla and hardly any anti Xa effect. Untill now, heparin-llke activity has on $y$ be demonstrated in a few case reports of patients with haematological malignancles (144). To our knowledge, such undenlable heparin-llke activity in normal indlviduals has never been demonstrated.

\section{References}

1. Sllxma, J.J. Role of blood vessel, platelet and coagullation interactions in haemostasis: In: Haemostasils and Bloom, ed. A.L. Bloom and D.P. Thomas, Churchill Livingstone, 252 (1981)

2. Zwaal, R.F.A., Hemker, H.C. Blood cell membranes and haemostasis. Haemostasis 11,12 (1982)

3. Doolitlle, R.F. Structural aspects of the flibrinogen to fibrin conversilon. Adv. Protein Chem. 27, I (1973)

4. Bennett. Bllood coagulation and coagulation tests. In: The medlical clinlcs of North Amerlca, 557, (1984)

5. Furlan, M. Structure and function of normal flbrinogen. In: Varlants of human flbrinogen, ed. E.A. Beck and M. Furlan, Hans Huber Publ. 55 (1984)

6. Doollttle, R.F. Fibrlinogen and flbrin. In: Bloom A.L. and Thomas D.F. (eds). Haemostasis and Thrombosis, Edilnburgh, Church lll Livingstone (1981).

7. Crabtree, G.R., Kant, J.A. Coordlinate accumulation of the mRNAs for the $a, \beta$, and $Y$ chains of rat fibrinogen following defibrination. $J$. Blal. Chem. 257, 7277 (1982)

8. Duckert, F., Jung, E., Shmerlling, D.H. A hltherto undescrlbed congenltal hemorrhaglc diathesis probably due to fibrin stablilizing factor deficlency. Thrombos. Dt Diathes. Haemorrhag. 5, 179 (1960)

9. McDonagh, J. Structure and function of Factor XIII. In: Colman, R.W., HIrsh, J., Marder, V.J., Salzman, E.W. (eds). Hemostas. and thrombos. Phlladelphla: Lipplincott, pp. 164 (1982)

10. Curtis, C.G., Brown, K.L., Gredo, R.B. et al. Calclum-dependent unmasking of active centre cystelne during activation of flbrlin stabllizing factor. Blochemistry 13, 3774 (1974)

11. Sakata, Y., Aokil, N. Cross-linking of alpha, - plasmin inhibitor to fibrin by fibrin-stablilzing factor. J. of Clln. Invest. 65,290 (11980). 
12. Iwanaga, S., Suzukl, K., Heshimoto, S. Borline plasma cold-insoluble globulin. Anin. of the Now York Acad. of Sclence 312, 56 (1978)

13. Mosher, D.F., Schad, P.E., Klellnman, H.K. Cross-llaking of flbronectin to collagen by blood coagulation factor Xilla. J. of clln. Invest. 64. 781 (1979)

14. Duckert, F. Documentation of the plasma factor XIII deficlency In man. Ann * of the New York Acad. of Sclence 202, 190 (1972)

15. Vane, H.J.R. Prostacyclin: a hormone ith a therapeutlic potentlal. J. of Endocr inology 95, 3P (1982)

16. Weksler, B.B., Ley, C.W., Jaffe, E.A. Stimulation of endothellall cell prostacycll in production by thrombin, trypsin and the lonophore A23187. J. of Cllin. Invest. 63, 1089 (1979)

17. Levin, R.l., Jaffe, E.A., Weksler, B.B. Nitroglycer In stimulates synthesis of prostacyclin by cultured human endothellal cells. J. of Ciln. Invest. 67, 762 (1981)

18. Alhenc-Gelas, F., Tsal, S.J., Callahan, K.S., Campbell, W.B., Johnson, A.R. Stllmulation of prostaglandin formation by vasoactive mediators in cultured human endothellal cells. Prostaglandins 24, 723 (1982)

19. Fleisher, L.N., Tall, A.R., Witte, L.D., Mlller, R.W., Cannon. P.J. Stimulation of arterlal endothellal cell prostacyclin synthesis by high densitiy Ilpoprotelns. J. of Blol. Chemlstry 257, 6653 (1982).

20. Whorton, A.R., Young, S.L., Data, J.1; Barchowsky, A., Kent, R.S. Mechanism of bradykinin-stimulated prostacyclin synthesis in porcine aortic endothelial cells. Blochlm. et Blophys. Acta 712, 79 (1982)

21. Eldor, A., Fridman, R., Vlodavsky, I. et al. Interferon enhances prostacyclin production by cultured vascular endothellal cells. J. of Clin. Invest. 73, 251 (1984)

22. Damus, P.S., Hicks, M., Rosenberg, R.D. Antlcoagulant action of heparin. Nature 246, 355 (1973)

23. Buonassisi, V., Root, M. Enzymatic degradation of heparin-related mucopolysaccharldes from the surface of endathellal cell cultures. Blochem. et Blophys. Acta 385, 1 (1975)

24. Siminonescu, M., Simionescu, N., Silbert, J.E., Palade, G.E. Differentlated mlcrodomalns on the luminal surface of the caplllary endothelllum, II. Partial characterlzation of their anlonlc sltes. J. of Cell Biology 90, $614(1981)$

25. Lämle, B., Grltfin, J.H. Formation of the fllbrin cliot: the ballance of procoagulant and inhlbitory factors. Clinlcs in Haematol chapter 1 , 14,281 (1985)

26. Trans, T.H., Bondell, C., Marbet, G.A., Duckert, F. Reactlvity of a hereditary abnormal antithrombin $\| 11$ fraction in the Irihlbition of thrombin and Factor Xa. Thromb. and Haenostas. 44, 92 (1980)

27. Kolde, T., Odanl, S., Takahashl, K., Ono, T., Sakuragawa, N. Ant 1thrombin 111 Toyama: Replacement of arglinine-47 by cystelne in hereditary abnormal antithrombin 111 that lacks hepar In blinding sites. Proc of the Nat. Acad. of SCl. (USA) 81, 289 (1984) 
28. Marcum, J.A., Rosenberg, R.D. Antlcoagulantly actlive heparin-like molecules fron vascular +1 ssue. Blochemlstry 23, 17307 (1984)

29. Stern, D.M., Nawroth, P.P., Kislel, W. et al. A coagulation pathway on bovlne aortlc segments leading to generatlion of factor $X a$ and thrombin. J. of Clin. Inwest. 74, 1910 (\|984)

30. Reutellingsperger, Ch.P.M., Hornstra, G., Hemker, H.C. Isolation and partlal purlfication of a novel antlcoagulant from arterles of human umbllical cord. Eur. J. Blochem. (In press)

31. Esmon, C.T., Esmon, N.L., Harrls, K.W. Complex formatlon between thrombin and thrombomodulin inhlbits both thrombin-catalyzed flbrin formation and factor $y$ activation. J. of Blol. Chem. 257, 7944 (1982)

32. Esmon, C.T." Esmon, N.L. Proteln C activation. Sem. In Thromb. and Hemostas. 10, 122 (1984)

33. Llebermann, G.E., Lewls, P., Peters, T.J. A membrane bound enzyme in rabblt aorta capable of Inhlbiting adenosine diphosphate Induced platelet aggregation. Lancet 2, 330 (1977)

34. Johnson, A.R., Erdos, E.G. Metabollism of vasoactive peptides by human endothellal cellis in culture. J. Clin. Invest. 59, 684 (1977)

35. Deykin, D., Cochlos, F., de Camp. G. Hepatic removal of activated factor $X$ by the perfused rabbit IIver. Am. J. Physlol. 214, 414 (1968)

36. Rosenberg, R.D., Rosenberg, J.S. Natural antllcoagulant mechanlsms. J. of Clin. Invest. 74, 1 (1984)

37. Abllagaard, U. Evidence that antithrombin 111 is the maln physlologlcal Inhibltor of coagulation enzymes. In: Collen D., Wiman, B., Verstraete, M. (eds). The physlological inhibltors of blood coagulation and fibrinolysis. 31,. Amsterdam: El sevier/North-Holl and (1979).

38. Lahlirl, B., Bagdasarlan, A., Mitchell, B. et al. Ant Ithromb in-heparlin cofactor: an inhlbitor of plasma kallikreln. Arch. of Blochem. and Blophysl. 175, 737. (1976)

39. Highsmith, R.F., Rosenberg, R.D. The inhlbition of human plasmin by human antlthrombin-hepar in cofactor. J. of Blologlical Chenlstry 249, 4335 (197.4)

40. Rosenberg, R.D., Damus, P.S. The purllfication and mechanism of action of human antithrombln-hepar in cofactor. J. of Blologlcal Chemistry 248, $6490(1973)$

41. Jordan, R., Beeler, D., Rosenberg, R.D. Fractlonation of low molecular welght heparin specles and thelr interaction with antithrombin. J. of Blologlical Chomistry 254, 2902 (1979)

42. BJgrk, 1. Nordenman, B. Acceleration of the reaction between thrombin and antlthrombin 111 by non-stolchlometric amounts of heparin. Eur. J. of Blochem Istry 68, 507 (1976)

43. Andersson, L.0., Barrowcl iffe, T.W., Holmer, E., Johnson, E.A., Sims, G.E.C. Antlcoagulant properties of heparin fractlonated by affinity chromatography on matr IX bound antithrombin $\| 11$ and by gel flitration. Thromb. Res. 9. 575 (1976) 
44. Harpel, P.C., Cooper, N.R. Studles on human plasma Cl-lnactlvatorenzyme Interactions. 1. Mechanisms of interaction with cis, plismin and trypsin. J. of Clin. Invest. 55, 593 (1975)

45. Harpel, P.C. Blood proteolytlc enzyme inhlbltors: their rolle in modulating blood coagulation and flbrinolytle enzyme pathways. In: Colman R.W., Hirsh, J., Marder, V.J., Salzman, E.W. (eds). Hemostasls and Thrombosis 738. Phlladelphla : Toronto: Lippincott. (1982)

46. Learned, L.A., Bloom. J.W., Hunter, M.J. The antithrombin actiwity of $\alpha$-protease inhlbitor: the antitrypsin activity of antithrombin \|\| . Thromb. Res. 8, 99 (1976)

47. Scott, C.F., Schaplra, M., James, H.L., Cohen, A.B., Colman, R.W. Inactivation of factor Xla by plasma protease Inhibitors. Predominant role of $\alpha_{1}$ protease inhibitor and protective effect of high molecular welght kininogen. J. of Cilin. Invest. 69, 844 (1982)

48. Collen, D. Natural inhlbltors of haemostasls, with partlcular reference to fibrinolysis. In Bloom A.L., Thomas, D.P. (eds). Haemostasis and Thrombosis 225 Edinburgh: Churchll| Livingstone (1981)

49. Salto, H., Goldsmith, G.H., Morol, M., Aokl, N. Inhlbitory spectrum of $\alpha_{2}-p$ lasmin inhlbitor. Proc. of the Nat. Acad. of Sell. (USA) 76, 2013 (1979)

50. Morol, M., Aoki, N. Inhibition of proteases in coagulation, kininforming and complement systems by $\alpha_{2}$-plasmin $\|$ inhlbitor. $J$. of Biochemistry 82, 969 (1977)

51. Harpel, P.C. Studies on human plasma $\alpha_{2}$-macroglobulin enzyme Interactions. Evidence for proteolytlc modification of the subunit chaln structure. J. of Exp. Med. 138, 508 (1973)

52. Harpel, P.C.. Rosenberg, R.D. $\alpha_{2}$-Macroglobulin and anti-thromb inhepar In cofactor: modulators of hemostatlc and inflammatory reactions. In: Spaet T.H. (ed) Progress In Haemostasls and Thrombosis 3,145 , (1976) New York: Grune \& Stratton (1976).

53. Schaplra, M., Scott, C.F., Colman, R.W. Contrlbutlon of plasma protease inhibitors to the inactivation of kallikrein in plasma. J. of Ciln. Invest. 69,462 (1982)

54. Shaplro, S.S., Anderson, D.B. Thrombin inhllbition in normal plasma. In: Lundblad R.L., Fenton, J.W., Mann, K.G. (eds) Chem. and Blol. of Thrombin 361. Ann. Arbor, Mlchlgan, Ann. Arbor Sclence Publ. (1977)

55. Tollefsen, D.M., Majerus, D.W., Blank, M.K. Heparin cofactor 11. Purlflication and propertles of a heparin-dependent Intilbitor off thrombin in human plasma. J. of Blol. Chem. 257, 2162 (1982)

56. Tolllefsen, D.M., Pestka, C.A., Monafo; W.J. Activation of heparin cofactor 11 by dermatan sulfate. 1 . of Blol. Chem. 258,6713 (1983)

57. Tran, T.H., Zblinder, B., Marbet, G.A., Duckert, F. Congenitel hepar In cofactor 11 ( $\mathrm{HClI}$ ) deficlency in a patlent with cerebral thrombosis. Thromb. Haemostas. Abstract San Diego, 49 (1985) 
58. Sle. P., Dupony, D., Borer, B. Constitutional hepar In cofactor II deflclency in a patlent with recurrent venous thrombosis. Thromb. and Haemostas. Abstract, San Dlego (1985)

59. Grlffin, J.H., Evatt, H.B, Zimmerman, T.S, Klellst. A.J. Wideman, C. Deflicliency of protein $\mathrm{C}$ in congenltal thrombotic disease. J. of Clln. Inv. 68, 1370 (1981)

60. Bertina, R.M., Broekmans, A.W., v.d. Linden, I.K., Mertens, K. Proteln $C$ defliclency in a Dutch famlly with thrombotlc disease. Thromb. and Haemost. 48, $1:(1982)$

61. Comp, P.C. Nixon, R.R., Cooper, M.R., Esmon, C.T. Famlllal proteln S deflelency is assoclated with recurrent thrombosis. J. of Clin. Invest. 74, 2082 (1984)

62. Schwarz, H.P., Fischer, M., Hopmeler, P., Batard, M.A., Griffln, J.H. Plasma proteln $S$ deficlency in famllial thrombotic disease. Blood 64 , 1650 (1984)

63. Klsiel, W. Human plasma proteln C. Isolation, characterlzation and mechanlsm of act I vation by thrombin. J. of Clin. Inv. 64, 761 (1975)

64. Esmon, C.T., Omen, W.G. Identiflcation of an endothellal cell cofactor for thrombin-catalyzed activation of protein C. Proc. of the Mat. Acad. Sel. (USA) 78, 2249 (1981)

65. Salem, H.H., Broze, Q.J., Mlletlch, J.P., Majerus, P.W. The llght chaln of factor Va accelerates proteln $\mathrm{C}$ activation by thrombin. J. of Blol. Chem. 258, 8531 (1983)

66. Salem, H.H., Esmon, N.L., Esmon, C.T., Majerus, P.W. Effects of thrombomodulin and coagulation factor Va-light chain on protein $C$ activation in vitro. J. of CIIn. Invest. 73, 968 (1984)

67. Kislel, W., Canfleld, W.M., Erlcsson. L.H., Davle, E.W. Anticoagulant properties of bovine plasma proteln C following activation by thrombin. Blocxhem Istry 16,5824(1977)

68. Grlfflln, J.H. Clinlcal studles of proteln C. Sem. In Thromb. and Haenostas. 10, 162 (1984)

69. Walker, F.J. The regulation of activated proteln $C$ by a new protelln: a possible function for bovine proteln S. J. of Blol. Chem. 255, 5521 (1980)

70. Gardlner, J.E*, Grlffin, J.H. Studles on human protein $C$ inilibitor in normal and factor $V$ and $V I \| l$ deflclent plasmas. Thromb. Res. 36, 197 (1984)

71. Nelsestuen, G.L., KIslel, W., DI Sclplo, R.G. Interaction of vitamin K-dependent protelns with membranes. Blochemlstry 17, 2134 (1978)

72. Dahlbäck, B. Interaction between vitamin $k$-dependent protein 5 and the complement proteln, $C_{4 b}$-binding protein. A link between the coagulation and the complement system. Sem. In Thromb. and Hemostas. 10, 139 (1984)

73. Suzukl, K., Stenflo, Ji, Dahlbäck, B., Toedorsson, B. Inactivatlon of human coagulation Factor $V$ by activated proteln C. J. of Blol. Chem. $25,1914(1983)$ 
74. Suzukl, K., Nishloka, J., Hashlmoto, S. Proteln C Inhlbltor. Purlflication from human plasma and characterization. J. of Blol. Chem. 258 , 163 (1983)

75. Aronson, D.L., Stewon, L., Ball, A.P., Franza, B.R., Finlayson, J.S. Generation of the combined prothrombin activation peptide (F.1.2) durling the clotting of blood and plasma. J. of Clin. Invest. 60,1410 (1977)

76. Collen, D. On the regulation and control of fibrinolysis. Thromb. Haemoastas. 43, 77 (1980)

77. Lynen, H.R., Hoylaarts, M., Collen, D. I solation and characterization of a human plasma proteln with affinity for the Iysine-binding sites in plasminogen. J. Blol. Chem. 225, 10214 (1980)

78. Emeis, J.J., Hinsbergh, V.V.M., Verheyen, J.H., WIJngaards, G. Inhibition of tissue type plasminogen activator by conditloned medium from cultured human and porcine vascular endothellal cells. Blochem. Blophys. Res. Comm. 110, 392 (1983)

79. Sprengers, E*D., PrIncen, H.M.G., Koolstra, T., HInsbergh V.V.M. Inhlbition of plasminogen activators by conditloned medlum of human hepatocytes and hepatoma cell IIne HepG 2. J. Lab. CIIn Med. 11985 . in press)

80. Aokl, N., Salto, H., Kamlya, T., Kole, KI, Satala, Y. Congenltal deflelency of $a_{2}$-plasmin inhlbltor assoclated ith severe haemorrhaglic tendency. J. Cl In. Invest. 63, 877 (1979)

81. Francls, C.W., Marder, V.J. Mechainisms of fibrinolysis. In: WHIllams W.J., Beutler, E., Erslev, A.J. et al. (eds). Hematology edition 3 . New York, McGraw-HIII Book Co. (1983)

82. Aokl, N. Genetic abinormalitles of the fibrinolytlic system. Sem. In Thromb. and Haenostas. 10, 42 (1984)

83. Bachmann, F., Krulthof, E.K.O. TIssue plasmlnogen activator: chemlcal and physlologlcal aspects. Sem. In Thromb. and Haemostas. 10,6 (1984)

84. Brommer, E.J.P. Brakman, P., Haverkate, F., Kluft, C., Traas, D., Wyngaerd, G. Progress in fibrinolysis. In: Recent Advances in blood coagulation, ed. L. Poller, Churchlll Livingstone 125 (1981)

85. Bleyer, W.A., Hakaml, N., Shepard, T.H. The development of hemostasls In the human fetus and newborn infant. J. of Pedlatrlics 79, 838 (1971)

86. Montgomery, R.R., Marlar, R.A., Gill, J.C. Newborn Haemostasls. In: Clinics in Haematology, chapter 6, 14:2 443 (1985)

87. Editorlal. Neonatal cerebral intraventrlcular heamorrhage. Lancet II I, 1341 (1976)

88. Buchanan, G.R. Neonatal coagulation: normal physiology and pathophyslology. In: Clinlos in Haematology, chapter 6, $7: 185$ (1978)

89. Jaffe, E.A., Hoyer, L.W., Nachmann, R.L. Synthesis of antihemophlllic factor antigen by cultured human endothellal cells. J. of cllin. Invest. 52, 2757 (1973) 
90. Blever, M.A., Hakaml, N., Shepard, T.H. The development of hemastasls in the human fetus and newborn infant. J. of Pediatrlcs 79, 838 (1971)

91. Montgomery, R.R., Marlar, R.A., Glll, J.C. Newborn haenostasls. In: Cinles in Haematology, chapter 6, $14: 2$ 443 (1985)

92. Mull. M.M., Hathaway, W.E. Altered platelet function in newborns. Ped. Res. 4, 229 (1970)

93. Corby, D.G., Schulmann, 1. The effects of antenatal drug administration on aggregation of platelets of newborn infants. J. Of Pedlatrles $79,307(1971)$

94. Corby, D.G., Zuck, T.F. Newborn platelet dysfunction: a storage pool and release defect. Thromb. and Hamostas. 36, 200 (1976)

95. Whaum, J.M. The platelet of the newborn infant. 5-hydroxytryptamine uptake and release. Thromb. Ot Dllath. Haemorrh. 30, 327 (1973)

96. Ts" a, C., Green, D., schultz, K. Function and ultrastructure of platelets of neonates: enhanced ristocetin aggregation of neonatal platelets. Brit. J. of Hemat. 32, 225 (1976)

97. Stuart, M.j. The neonatal platelet: evaluation of platelet malonyl dlaldehyde formation as an Indlcator of prostaglandin synthesls: Brit. J. of Hemat. 39, 83 (1978)

98. Del Prlnclpe, D., Gabrlottl, M., Mastracchlo, F., Menlnchelli, A., Glardinl, 0. Malonyldlaldehyde formation, oxygen consumption, fatty acld composition in newborn pllatelets stimulated by thrombin. Blol. of the Noenate 36, 49 (1979)

99. Corby, D.G., Goad, W.C., Barber, J., O'Barr. T.P. Evaluatlon of cyclo-axygenase pathway in platelets of the newborn. Thromb. and Haemostas * 38, $35(1977)$

100. Maak, B., Frenzel, J., Rogner, G. Untersuchungen der Thrombozytenaggregation und der Gerinnselretraktion bel relfen und unrelfen Neugeborenen. Zeltsch. für KInderhellk. 111, 325 (1972)

101. Altemeyer, K.H., Burgdorf, A., van Lucadu, I, Schenck, W., Kunzer, W. Zum Funktionel len Verhalten der Thrombozyten In KIndesalter. Zeltschr. KInderhellk. 113, $257(1972)$

102. Sutor. A.H., Heldmann, M*, Künzer, M. Die Blutungszeltbestlmmung Im Kindesalter und lhre klinische Anwendung. Medizinlsche Welt 25 . $401(1974)$

103. Levine, P.H. Platelet-function tests: predictive value. New Eng. J. of Mad. 292, 1346 (1975)

104. Barnard, D.R., Simons, M.A., Hathaway, W.E. Coagullation studles in extremely premature Infants., Ped. Res. 13, 1330 (1979)

105. Barnard, D.R. Inherlted bleeding disorders in the newborn infant. Clin. In Perlinatology 11, 309 (1984)

106. Corrlgan, J.J., Sell, E.J., Pagel, C. Hageman factor and dissemlnated Intravascular coagulation (DIC) In newborns and rabbits. Ped. Res. 11 , $916(1977)$ 
107. Gordon, E.M., Ratnoff, O.D., Salto, H., Gross, S., Jones, P.K. Studias on some coagulation factors (Hageman factor, plasma prekallikrein and high molecular welght kininogen) in the normal newborn. Am. J. of Pediatr. Hemat/Ocol. 2, 213 (1980)

108. Hathaway, W.E. Haemostatic disorders in newborn. In: Bloom (ed) Haemostasis and Thrombosis, chapter 25, p. 439 Churchili Livingstone (1981)

109. Hathaway, W.E., Bonnar, J. Perlnatal coagulation. Grume and Stratton, New York, (1978)

110. Sell, E.J., Corrlgan, J.J. Platelet counts, flbrinogen concentrations and factor $V$ and factor $V I 11$ levels in healthy infants according to gestational age. J. of Pedlatrics 82, 1028 (1973)

111. Peake, I.R., Bloom, A.L., GiddIngs, J.C., Ludlam, C.A. An Immunoradlometrlic assay for procoagulant factor Vill antligen: results in haemophllla, von WIIllebrand"s dlsease and fetal plasma and serum. Brit. J. of Heinat. 42, 269 (1979)

112. Hendrlksson, P., Wesstrom, G. "Hedner, U. Umblllical artery catheterlzation in newborns. IIll. Thrombosils -a study of some preallisposing factors. Acta Paed. Scand. 68, 719 (1979)

113. Maak, B., Scheidt, B., Frenzal, J. Factor WIII actlvity and factor VIII rellated antigen in newborns. Eur. J. of Paed. 128, 283 (1978)

114. Fukul, H., Takase, T., Ikarl, H., Murakami, Y., Okubo, Y., Wakamura, K. Factor VIll procoagulant activity and von Willebrand factor In newborn cord blood. Brlt. \&. of Haenat. 42, 637 (1979)

115. Johnson, S.S., Montgomery, R.R., Hathaway, W.E. Newborn factor VIII complex: elevated activities in term infants and alterations in electrophoretlc mobllity related to illness and activated coagulation. Brit. J. of Haemat. 47, 597 (1981)

116. Jensen, A.H., Josso, F., Zamet, P., Monset-Couchard, M., Minkowskl, A. Evolution of blood clotting factor levels in premature infants durling the first 10 days of 11 fe: a study of 96 cases with compar lson betwoen clinical status and blood clotting factor levels. Ped. Res. 7, 538 (1973)

117. Holmberg, L., Hendrlksson, P., Ekelund, H. Astedt, B. Coagulation In the human fetus: comparison with ferm newborn infants. J. of Pedlatrlics 85, 860 (1974)

118. Muntean, W., Petek, W., Rosanell 1, K., Mutz, I.D. Immunologle studles of prothrombin in newborns. Ped. Res. 13, 1262 (1979)

119. van Doorm, J.M., Muller, A.D., Henker, H.C. Heparin-like Inhlibitor, not vitamin $K$ deficlency in the newborn. Lancet, 1: 852 (1977)

120. Gobel, U., Sonnenscheln, Kosenow, S., Petrlich, C., von Woss, $H$. Vitamin K-deflclency in newborn. Lancet 2, 187 (1977)

121. Aguerclf, M*, Glacomett1, N., Nlgg, O.M., Lacourt, G., Bouvler, C.A. Exlste-t-ll un fibrinogene foetall Expllaration statlstlque de la fibrinoformation dans une population de nouveau-nés prematurés, matures et post-matures. Pedlatrle 28, 381 (1973) 
122. Witt, 1., Hasler, K. Influence of organlcally bound phosphorus in fetal and adult $f$ ibrinogen on the kinetics of the Interaction between thrombin and flibrlnogen. Blachim. et Blophys. Acta 271, 357 (1972)

123. Galanakis, D.K., Mosesson, M.W. Correction of the delayed fibrin aggregation of fetal flbrinogen by partlal removal of slallc acid. Thromb. and Hamostas. 42,79 (1979)

124. Yamada, K., Shlrahata, A., Meguro, T. The comparative studies on factor $x_{11}$ of newborn. Infants obtained by three methods: cllot solubllity, Immunologlcal and fluarascent assays. Acta Haemat. Japonlca $39,79(1976)$

125. Hendriksson, U., Hedner, U., Nilsson, I.M., Boehm, J., Robertson, B., Lorand, L. Flbrin-stabllizing factor (Factor $X\|\|$ ) in the fetus and the newborn Infant. Ped. Res. B, 789 (1974)

126. Teger-Nilsson, A.C. Antlthrombin in Infancy and chlldhood. Acta Paed. Scand. 64, 624 (1975)

127. Weissbach, G., Domula, M., Lenk, H., Schneider, P. The progresslve antlthrombin actiwity and its relations to other factors of the coagulation system in newborns. Acta Paed. Scand. 67, 555 (1974)

128. McDonald, M.M., Hathaway, M.E., Reeve, E.B., Leonard, B.D. Blochemllcal and functional study of antlthrombin 111 in newborn infants. Thromb. Haomostas. 47, 56 (1982)

129. Peters, M., Jansen, E., Ten Cate, J.W., Kahlé, L.H., Ockelford, P., Breederveld, C. Neonatal antithromb In III. Brlt. J. Haemat. (In press, 1985)

130. Ekelund, H., Hedner, U., Nilsson, 1.M. Flbrinolysils in newborns. Acta Paed. Scand. 59, 33 (1970)

131. Schettini, F., de Mattia, D., Montagna, O., Altomore, M. Svilluppo postnatale dell'antlthromblna 111 , del plasminogeno e dell" $\alpha_{2}$-macroglobullina nell 'uomo. Rlvista Ital lana Pedigtrla 2, 315 (1976)

132. Harpel, P.C., Rosenberg, R.D. $\alpha_{2}$-macroglobulin and antithromblinhepar In cofactor: modulators of hemostatlc and inflammatory reactions. In: Spaet TH (ed) Progress In Haemostas is and Thrombosis 145 New York: Grune and Stratton (1976)

133. Polack, B. et al. Proteln C level at blrth. Thronb. Haemostas. 52:2, 188 (1984)

134. F. Schettinl et al. Post-natal development of proteln $C$ in full-term newborns. Acta Paed. Scand. $74: 2$ 226 (1985)

135. Marllar, R.A., Klelss, A.J., Griffin, J.H. Mechanlsm of action of human activated proteln $C$, a thrombln-dependent anticoagulant enzyme. Blood 59. $1064-1072$ (1982)

136. Branson, H.E., Katz, J., Marble, R., Grlffin, J.H. Inherlted protein C defliclency and coumarin-responsive chronlc relapsing purpura fullminans syndrome in a reonate. Lancet 11, 1165 (1983)

137. Sellgsohn, U., Berger, A., Abend, M. et al. Homozygous protein C defliclency manlfested by massive venous thrombosis in the newborn. New Eng. J. of Med. 310, 559 (1984) 
138. Sllls, R.H., Marlar, R.N., Montgomery, R.R., Despande, G.N., Humbert, J.R. Severe homozygous proteln C defliclency. J. of Pedlatrlics 105, 409 (1984)

139. Ekelund, H., Finnstrom, 0 . Fibrinolysis in preterm infants and in Infants small for the gestational age. Acta Paed. Scand. 61,185 (1972)

140. Markarlan, M., Githens, J.H., Jackson, J.J., Bannon, E.A., Lindley, A., Rosenblut, E., Martorell, R., Lubchenco, L.O. Flbrinolytlic activity in premature infants. Am. J. of Disease of Chlld 113, 312 (1967)

141. Olexa, S.A., Budzynskl, A.Z. Evidence for four different polymerzlation sites inwolved in human flbrin formation. Proc. Natl. Acad. Scl. USA 77, 1374 (1980)

142. Lorand, L., Stenberg, $P$. Endo-, $\gamma$-gllutamine: $\varepsilon-1$ ysllne transferases. Enzymes which crosslink protelns. In: Fasman G. (ed) Handbook of Blochemistry and Molecular Blology. Protelns Vol 11, p. 669. Clevelland Ohlo, CRC Press (1976)

143. Henker, H.C., Hemker, P.W., Torren, K.v.d., Devllée, P.P., Hermens, W.Th. and Loellger, E.A. The evaluatlon of the two stage prothrombin assay. Thromb. Diath. Haemorrh. 25, 545 (1971)

144. J.W. Bussel et al. A heparin-llke antlcoagulant in an B-month old boy w th acute monoblastlc Heukemla. Am. J. of Hemat. 16:1, 83 (1984) 

CHAPTER 2

\section{VITAMIN K AND THE NEWBORN}

1. Introduction

2. Vitamin $K$ deficiency in newborns: posslble mechanlsms

3. How to diagnose a vitamin $K$ deflclency

4. The situation before, at and after birth

5. Conclusions and recommendations 
1. Introduction

Studyling the effects of a cholesterol-free dlet on chickens, Dam (1) notlced that after some weeks the anllmals developed a haemorrhaglic diathesis, which could not be counteracted by adding purlfled chollesterol to the food, but furned out to be related to the deficlency of a fat soluble vitamin, which was called vitamin K (Koagulatlons Vitaminl. It was postulated that vitam In $K$ was essentla! for the synthesis of a number of protelns involved in bllood coagulation. VItamin $K$ was also Involved in the haemorrhagle disease in cattle, known since 1921 in the USA and Canada* Campbell and Link (2) have demonstrated that this dlsease was caused by the presence of coumar in derlvatlves in sweet clover hay. These 4-hydroxy coumarins are antagonlsts of vitamin $k$. It would take more than 30 years after these inltial observations to galn more insight in the mode of action of vitamin $K$ and to determIne at what stage of the proteln synthesis vitamin $k$ is Involved. The first breakthrough came in 1963, when Henker et al. descrlbed that blood from patlents recelving orall antlcoagulant therapy contalns a mixture of normal and abnormal prothrombin (3a). This abnormal prothromblin was first called preprothrombin (3a) and 5 years later uprotein Induced by Viltamin $K$ Absence" or PIVKA ( $3 b$ ) and it was regarded as a precursor of prothrombin. It was postulated that this abnormal prothrombin could not be activated to form thrombiln under physlologlcal conditions. It was shown that abnormal prothrombin is similar to normal prothrombin with respect to its molecular size, Its number of siallic acid residues, its amino acid composition and Its antigenic activity (4). However, in the presence of $\mathrm{Ca}$, the electrophoretic migration rate of abnormal prothrombin was different. Thls appeared to be due to the fact that abnormal prothrophin is not able to bind $\mathrm{Ca}^{++}$whereas prothrombin has a high affinity for $\mathrm{Ca}^{(5)}$. In 1974 it was reported Independently by two groups $(6,7)$, that the calclum-blinding sites in normal prothrombin were gamacarboxyglutanic acld ( $\theta \mid a)$ resldues, and that these resldues were glutamic acld (Glu) resldues In abnormal prathromblin. The onl $\chi_{+}$known physlologlcal slgnificance of Gla residues is related to their $\mathrm{Ca}^{+}$blinding propertles. For instance, the formation of thrombin is enhanced in the presence of $\mathrm{Ca}^{++}$and negatively charged phosphollplds (B). Vitamin $K$ dependent protelns are also linvolved In the calclum transport from the egg shell to developing chlcken embryos (9) and In the regulation of the calclum phosphate deposition in the bone matrlx $(10)$. All vitamin $k$-dependent protelns discovered up till now belong to what are called the secretory protelns: the protelins which are secreted after maturation into the extracellular flluid. Vitamin $k$ is involved in a carboxylation reaction, whloh is a posttranslational step in the synthesis of Gla-contalning protelins (11). Enzymes involved in posttranslational modiflications are located in the Inner side of the endoplasmic tubular system. The vittaniln $\mathrm{K}$-dependent carboxylase has been studied most extensilvely in liver mlcrosomal preparations obtal ned from rats and cows. Absolute 
requirements for the witamin $K$-dependent carboxylase are witam in $K$ hydroquinone for vitamin $K$ quilnone in the presence of reducing agents such as $\mathrm{NAD}(\mathrm{P}) \mathrm{H}), \mathrm{O}_{2}, \mathrm{CO}_{2}$ and a carboxylatable substrate. Several stlmulators and Inhlbltors have boen descrlbed, malnly based on in witro studles.

in the liver, vitamin $K$ is partly present in the form of its 2,3 epoxide (12). The epoxlde can be reduced to vitamin $K$ qul none by vitamin $K$ epoxider reductase and further to the hydroquilinone by NAD (P)H dehydrogenase (13) and/or vitamin $K$ reductase. Thls course of events is called the vitamin $K$ cycle. The blological function of the vitamin $K$ cycle is thought to be the constant preservation of vitamin $K$ hydroquinone, which is used in the carboxylation reaction. Carboxylation without epoxidation has never been demonstrated and the concept that both events are coupled in some way has generally been accepted at this time (11).

During the last few years, a number of Investigators has reported the presence of vitamin K-dependent carboxylase in non-hepatic tissues $(10,17$, 18, 19). Microsomal carboxylases and substrates were found in bone, testls, kldmey, spleen, lung, thyrold, pancireas, thymus, placenta and arterles; it has not been found in veins, brain, leukocytes and muscles. The Importance of these carboxylases as well as the function of the carboxylated reaction products remains to be establlished as yet. The vitamin K-dependent protelns Involved in the haemostatic reaction are all synthesized in the llver. The four vitamin $\mathrm{K}$-dependent coagulation factors are Involved in the formation of thrombin from prothrombin. Thrombin acts as a key enzyme in the haemostatic mechanism. It converts flbrinogen Into flbrin and it activates factor $\times 111$, which in its activated form provides a crossilinking of fibrin monomers. More important is the fact that thrombin in vivo as well as in vitro is a potent actlivator of blood platelets. It al so stimulates its own formation by activation of two other coagulation proteins, the factors $v$ and vill. Protelin C is a vitamin K-dependent zymogen, which, when activated, functions as an anticoagulant. The physlologic activator of protein $C$ is belleved to be thrombin in complex with an endothellial cofactor, thrombomodul in (20). Actlvated proteln C proteolytlcally degradest coagulation factors Va and VIII vity in plasma (22). Proteln $S$ is another vitamin $K$-dependent antlcoagulation factor which acts by Increasing the rate of inactivation of factor Va by activated proteln C. Deflclency of proteln C as well as protein $S$, is assoclated with an incraased risk for thrombosis $(23,24)$.

\section{VItamin $K$ deficlency in newborns: possible mechanisms.}

Vitamin $K$ deflciency may occur in both acutely 111 and healthy appearing neomates and can be encountered. In a wlde varlety of clinical situations. This is summarized in table 1. 
Condlions assoclated wth $v i t a m i n k$ defliclency in infants and neonates

\author{
Ref. no. \\ 25,26 \\ 31,32
}

1 maternal drug Ingestion

2 decreased exogenous Intake (dletary Intake) $27,28,29,30$

3 decreased endogenous production

- antiblotic therapy

- ? slow gut colonlzation

- $?$ gut collonlzation by non vitamin

K-producling bacterla

4 Melabsorption of fat

- Infectlous dlarrhoea

$27,30,32,33$

- Intestinal resection

34 (p 924)

- cholestyramine administration

34 (p |103)

- cystlc flbrosis

35

- cholestatic IIver disease 60.9 . blll lary atresla, $\alpha_{1}$-antitrypsin defliclency) 36

- abetal ipoprotel naemia

According to some authors another possiblility is fallure to administer vitamin $K_{1}$ at birth (38). However, It is not to be expected that one dosage of vitamin $K$ at birth is able to provide protection for more than a few days, because the half 11 fe time of the vitamin is short (2-4 hours). Even, if one assumes, that vitamin $k$ is recycled many times in the tissues and that dosages are given far above the physlological requirements, it is hard to belleve that the effect wll last for more than one week. Another Important teature is the placental transfer to vltamin $K$.

Recently It has been demonstrated by several authors $(39,40)$ that there is a placental barrier of the transfer of vitamin $K_{1}$. Fron these studies, it may be concluded, that when the vitamin $K$ supplles are low in the mother the fetus is relatively more at rlsk for developling a vitain $K$ deflclency and that repeated and relatively high dosages are required to correct thls state. Thls could be a posslble explanation for the fact that a vitamin $K$ deflclency is more frequently found in for instance South East Asla, Japan and South Afrlca (blacks) and is probablly due to a lower soclaeconomic status in general $(41,42)$. In these countrles a vitamin $K$ deficlency is found at birth as well as in the flrst 6 months of IIfe. However, also in the western world a number of reports have been published, whilch Indlcete an Increased incldence of the haemorrhaglc disease of the newborn, a disease flrst descrlbed by Townsend in 1894 long before the discovery of vitamin $K(43)$. 
The classlcal haemorrhaglc disease of the newborn occurs in the first week of $1 / \mathrm{fe}$, Independent of trauma, Infection or anoxl after an uneventful pregnancy and dellvery In apparantly normal healthy newborns. In the recent Ilterature, the Increased incldence of this disease has been attrlbuted to the Increase In alternative birthing and breast feeding $(38,44,45)$, whlich might favor the development of a vitamin $K$ deficlency. Another haemorrhagle syndrome occurs in newborns between 1 and 6 months after birth, whlch is almost exclusively found in breast-fed infants and also attrlbuted to a vitamin $K$ deficlency $(28,32,41,46)$. There is also a tendency in the recent literature to recommend prophylaxis with vitamin $k$ to all newborns at birth as well as in the first months of IIfe in breast-fed Infants, in spllte of the fact that especlally in the western world only a small minority of the patlents wlll develop a vitamin $K$ deflclency. In a recent survey from Japan the inclidence of vitamin $K$ deficlency was 1 : 4500 unselected Infants and 1 : 1700 breast-fed infants (47). However, Intracranial haemorrhage was present in $81 \%$ of the affected chlldern. This is seen as a strong argument In favor of the vitamin $K$ prophylaxls in all newborns and especially in breast-fed newborns. In previous work of our laboratory, no evldence of a vitamin $K$ deflclency in healthy full term infants at birth and in the third day of life could be demonstrated 657 . It was concluded that vitamin $K$ shoull not be given to all newborns, but on Indlcation in high rlsk groups. Recent llterature data caused us to reassess our oplinion on the vitamin $k$ problen in newborns. Therefore, we trled to answer the following questlons:

- How to dlagnose a vitamin $\mathrm{K}$ defliclency?

- Whlch factors determine the vitemin $K$ deficlency, descrlbed in newborns at several time points before and after birth?

- Does vitamin $K$ prophylaxis reduce the incidence of major bleading problems in newborns and should all bables therefore recelve witamin $k$ prophyllaxis?

3. How to dlagnose a vitamin $K$ deflclency

Coagulation abnormalities are commonly observed in 111 newborns. Haenorrhaglc problems in acutely 111 newborns occur most commonly ith thrombocytopenla due to sepsis and disseminated intrevascular coagulation (DiC) (44). In contrast, an apparantly healthy newborn with haomorrhage should be suspected to have a vitamin $K$ deflclency (48). The laboratory dlagnosis of a vitamin $K$ deficlency depends not only on the methods used in the laboratory but also on the quallty of the sample. $1+$ will be clear that obtaining adequate material from newborns is a difficult task. In our experlence newborn blood is more suspectlble for in vitro (and/or in vivo?) proteolytic breakdown, in partlcular that of flbrlinogen. Therefore we recommend the bllood to be collected in Hepes buffered cltrate to whlch aprotonine is added and the plasma rendered platelet free by a second run at $20.000 \mathrm{~g}$. Another important factor is the haenatocrit. In the first week of Ilfe the haematocrlt values can show substantlal differences and it is 
reported that in $10 \%$ of all newborns hamatocr it values of 0.60 and aven higher are found (49). In polycythaemla fallse prolongation of the prothrombin time has been descrlbed due to an excess of cltrate. Many authors use the prgthrombin the or one of its modiflcatlons, the Normotest and Thrombotest, as evldence for an underlying vitamin $K$ deflclency. Although a prolongation of the clotting times obtained with these assays can be caused by a vitamin $K$ deflciency, also other factors can be responsible, such as proteolytic degradation products and high haematocr it values. We have found a poor $R_{\text {correlation between }} p R^{\text {thrombin }}$ coagulation activity levels, Thrombotest walues and Normotest values, thus Indlcating the llmited valldity of these overall clotting tests in the dlagnosls of a $v i t a m i n k$ deflelency, unless the values are extremely low. These tests are therefore less rellable for provlding evidence for a vitamin $K$ deflclency In newborns or that vitamin $K$ given to newborns "improves" the coagulation abnormalitles, as is often done, especialiy in the older literature. Prothrombin levels can be measured more rellable in several ways. In the one stage assay using human prothrombin deflclent plasma (50) the blologlically active prothromblin is measured.

In the following tests total prothrombin protein is measured, including that which is functionally inactive (descarboxy-prothromb in) which is expected to be present in plasma in the case of a vitamin $K$ defliclency:

1. The one dimensional rocket Immunoelectrophoresis according to Laurell measures the factor it rellated antigen using a preclpltating antibody (51).

2. The Echls Carlnatus test, using saw-scaled viper venom, which enzymatically activates prothrambin into thrombin in the absence of Ilpld and calclum (52).

3. The staphylocoagulase reacting factor assay (53).

In most studles a discrapancy between the factor 11 clotting activity level. and the factor 11 antigenlc level via method 1 is taken as evldence for a vitamin $K$ deflcloncy, when the factor 1 " $/$ factor 1 ll is below 0.8. Thls method is rather Insensitive and requires at lleast: $5 \%$ descarboxy-prothrombin present in the sample. Another Immunological method often used is the two dimenslonal crossed Immunoelectrophoresis. In the first dimension calclun lactate is added (5 mM/l) in the running buffer. Prothromblm and descarboxy-prothrombin have a difterent migration pattern, which can be visualized in the second dimension where human precipltating antlibody agajnst prothrombin is used. Because descarboxy-prothrombin does not bl nd Ca it migrates faster to be anodal site (54). This mothod is not quantitative and also rather Insensitive. As yet the most sensitive method for the determination of descarboxy-prothrombin has been deseribed by Furlo, using a radiolmunoassay with a speciflc antibody against descarboxy-prothronbln (55). Recently this method was used to evaluate the vitamin $K$ status of newborns and thelr mothers (63). They found a mean 
levell of descarboxy-prothromblin of $0.35 \mu \mathrm{g} / \mathrm{m} /(0.001-78 \mu \mathrm{g} / \mathrm{ml})$ in newborns and $0.06 \mu \mathrm{g} / \mathrm{ml}(0.001-1.01 \mu \mathrm{g} / \mathrm{m}$ ) for the mothers, whereas $1+$ was undetectable in normal subjects. The results were dotalned in palred cord serum samples of 181 term newborns and their mothers at del lvery. In one Japanese report (56) an enzyme-l Inked Immuno-sorbent assay using monoclonal ant 1bodles agalinst descarboxy-prothrombin was applled in 4 Infants, ranging in age from 27-42 days ith suspected vitamin $K$ deflclency. In these Infants the levels of descarboxy-prothromb in were much hlgher than in the controls. Another approach was published by Atkinson (42) who devlsed a rapld and sensitive spectrophotometrlc assay based on the abllity of dispholldus typus venom to activate prothrombin remaining in plasma absorbed with aluminlum hydroxide gell. The non absorbable descarboxy-proteln was expressed as rate of reaction of non absorbed plasma $\times 100$. The authors claim that descarboxy-prothrombin levels can be detected wla this method up to $0.1 \%$ of the total prothrombin level. They found detectable descarboxyprothrombin in 48 out of 128 umbllical cord plasma samples.

Many authors emphasize the importance of the effect of the adminlstration of vitamin $K$ as a diagnostic tool for a vitamin $K$ deflclency state. Recently, It has become possible to measure directly the vitamin $K_{1}$ levels in plasma, using HPLC method after lipld extraction (39). In this study, the majorlty of the umbllical cord plasme samples appeared to have low or even non-detectable amounts of vitamin $K_{1}(39)$. This has been taken as a definite evidence for the occurrence of a vittanin $k$ deflclency in the majorlty of all newborns. However, determlinatlon of vltamin K, in plasma Is still a controverslal subject. It may also be questloned if this method reflects the amount of vitamin $K$ in the target tissues and if for Instance in newborns the low levels can also be explallned by the markedly lower levels of the transport lipoprotelns and album or a markedly higher

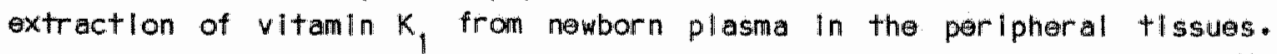
Moreover, the amount of witamin $K$ requlred is unknown and vitamin $K_{1}$ represents not the total vitamin $K$ pool. Up till now these interesting results have not been confirmed by other groups.

In our laboratory we use as a screening procedure for a vitamin $K$ deflelency the ratio of Ilc (prothrombin clotting activity) levels and total prothrombin levels as measured Immunologlcally (rocketimmunoelectrophoresis) or by the Echls Carlnatus test.

\section{Factors whllch may determine vitamin $\mathrm{K}$ defllclency}

In humans, the dally requirement of vitamin $K$ Is estimated to be very low. For adults it is supposed to be in the range of $0.05-1.5 \mathrm{~g}$ per $\mathrm{kg}$ welght per day (58). Food and the intestllnal bacterlal flora may serwo as sources for witamin $K$. Vitamin $K_{1}$ (phylloqulnone) is thought to be the most important form and is synthesized by green plants. Therefore, it is mainly present in vegetables. The intestinal bacterlal flora produces the famlly of the $K_{2}$ vitamins, the menaquinones, which differ from each other by their 
side chaln length. Up tilll now, only vitamlin $k_{1}$ epoxide has been denonstrated in human plasma (59). However, $K{ }^{-v i t a m i n s ~ h a v e ~ b e e n ~ d e m o n s t r a t e d ~}$ In the llver and are said to form $50 \%$ of the total vitamln $k$ pool $(60)$. Furthermore, in adults deprlved of food, a vitamin $K$ deficlency is rarelly found, unless also the bacterlal flora ls disturbed for Instance by using antiblotics. The role of the $k_{2}$ vitamins in the synthesis of the vitamin $k$-dependent (antli-coagulation factors remalns unclear. In newborns the dally requilrement of witamin $k$ is unknown, but it might be higher than in adults. It could be that newborns utllize much more vitamin $k$ for the synthesls of non-hepatic vitamin $K$-dependent protellins, such as the bone Glamprotein osteocalcin, which is involved in the regulation of calclum preclpltation in the bone matrix and the synthesls of which is remarkably high in rapldly growling bones $(62)$.

4a. The situation betore birth

Only a few studles have been performed to assess the anount of the vitamin $K$-dependent coagulatlon factors before birth. These data are summarlzed in table 2.

TABLE 11

\begin{tabular}{lccccccc}
\hline & $\begin{array}{l}\text { gestational } \\
\text { age (weeks) }\end{array}$ & \multicolumn{5}{c}{ Coagulation factors (units/mi) } & sampling* \\
\hline HelnkInhelno(64) & $12-16$ & 0.38 & - & 0.18 & - & - & 1 \\
Fortune(65) & $\| 1-22$ & - & - & - & - & $<0.01$ & 1 \\
Holmberg(66) & $12-24$ & - & - & - & - & $0.14-0.40$ & 1 \\
Mibashan(67) & $16-22$ & - & - & - & - & $0.08-0.18$ & 2 \\
Terwle\|(68) & $18-24$ & 0.16 & 0.19 & 0.21 & 0.19 & 0.04 & 1 \\
\hline
\end{tabular}

1. Materlal obtalned vila abortion

2. Materlal obtalned via fetascopy

Terwlel found in the majority of the fetal samples no discrepancy between different factor 11 determinations. In one sample a small amount of factor $\|$ related antigen was observed, compatible with the presence of amall amount of descarboxy-prothrombin or Indlcatlive for activation of the sample leading to proteolytle breakdown of prothrombin. Activation of the blood samples appears to be a major problem in the interpretation of the values found, especlally in the first reports on fetal development of haemostasls. We were able to study a small number of plasmas abtalned via fetal blood sampling in utera. These samples were klndly provided by Dr. F. Forestler, (Hôpltal N.D. de Bon Secours, Parls). This group has developed a new and safe method for fetal blood 
sampling in utero, usling ultra sound guldance of the needle and asplratlo $n$ of the blood from the umbllical veln at the placental cord Insertion (69). In their hands this method has proved to be safe (no abortion in more than 400 cases) and to provide adequate materlal for haemostatlc studles. Wo could conflirm their results and found no evidence for the presence of descarboxy-prothrombin in fetal plasmas. The prothrombin levels gradually increased from $19 \%$ (week 21) to 32\% (week 33).

Sumarlzing the scarce data available, no evidence is present at the moment for a vitamin $K$ defllclency during pregnancy in normal healthy Intants in the western world, provided that the mother is not vitamin $k$ deficlent. In the western world only a small number of pregnant women is at rlsk for a vitamin $K$ deflclency, for instance by nutritional deficilency, disturbance of intestinal resorption and the use of drugs interferlng with the vitamin $K$ mechanlsm, such as the coumarin derivatives and antlconvulsant drugs *

4b. The situation at birth

It has been well establlished that all the vitamin K-dependent procoagulants (the factors $|I, V \| I|$,$X and X$ ) are reduced in both the term and preterm infant $(70,66,71,72,73,74)$. In table 111 the range observed or the mean values \pm standard devlations from these studles are given of the vitamin K-dependent coagulation factors in preterm (27-31 weoks) and term Infants (38-41 weeks) at birth as a percentage of the normal adult values. These data are based on clotting activity assays.

TABLE \|\|

\begin{tabular}{|c|c|c|}
\hline$\because$ & $\begin{array}{l}\text { preterm Infants } \\
27-31 \text { wks }\end{array}$ & $\begin{array}{c}\text { term infants } \\
38-41 \text { wks }\end{array}$ \\
\hline factor 11 (prothrombin) & $30 \pm 8$ & $54 \pm 15$ \\
\hline factor VIII & $24-76$ & $35-82$ \\
\hline factor $1 X$ & $17-20$ & $21-39$ \\
\hline factor $x$ & $14-70$ & $33 \pm 13$ \\
\hline
\end{tabular}

Most studies on the viltanin K-dependent coagulation factors in newborns have been focused on the prothrombin (factor III) levels. In all studles a quantltatlve reduction of the prothrombin levels is found, using clotting activity as well as Immunologlcal methods. In the case of a vitamin $K$ deflclency uncarboxylated precursor molecules are secreted into the circulation, for instance descarboxyprothrombin. The methods avallable at the moment to assay the presence of descarboxyprothrombin have been discussed in the section "how to dlagnose a vitamin $k$ 
deflelency" of this chapter. Whether at birth descarboxyprothrombin can be demonstrated is controversilal in the literature.

In most West-European studies $(74,75,76,77)$ descarboxyprothrombin could not be demonstrated. Thls has been refuted by Muntean (78) who found a sllightly altered prothrombin peak on crossed immunoelectrophoresls, compatible with changes usually seen in vitamin $k$ deflciency in a small number of "normal" infants. Recently other reports have been publlshed In the United States $(80,63,42)$ and South Afrlica (42) Indicative for the presence of low amounts of descarboxyprothromblin in umblllcal cord plasme, using newer and more sensitive methods. These methods detect descarboxyprothrombin in concentrations as low as $0.01-1.6$ of the total prothrombin. In the study of shaplro et al. (79) umbillical cord plasmas of 917 newborns were investigated. This method is based on the presence of prothrombin related antlgen after two adsorption steps with barlumcltrate. Descarboxyprothrombin is not bound to barlumeltrate in contrast to prothrombin. The authors clalmed that all normal prothrombin can be removed by this procedure. In 2.99 of the cases descarboxyprothrombin (1.e. prothrombin related antigen after barlumcltrate) cauld be demonstrated. The Incldence was sllghtly hilgher in infants born of mothers with hypertension and dlabetes mellitus and those who had received antibiotics. The incidence was also higher in infants wth infectlous compllcatlions at blrth, resplratory distress syndrome and polycythaemla. In normal Infents born of normal mothers the incldence was less than 17. Atkinson found in his study (42) descarboxyprothrombin in 368 of the cases, using a more sensitlve method (detection $\|$ m $\mid+0.1 \%$ of the total prothrombin level). In the study of Blanchard (63) $90 \%$ of al newborns $(N=181)$ had detectable descarboxyprothrombin in cord serum, using the most sensitive method avallable at the moment (RIA with a speciflc antibody agellist descarboxyprothrombln). In the South Afrlcen study (42) especlaily black infants appeared to have detectable descarboxyprothrombin in thell umbllical cord plasma. The authors hypotheslze that thls might be due to different food patterns and socioeconomlc status off the black population. In the other studies these factors are not consldered. Although it may be questlioned, whether these very low amounts of descarboxyprothrombln are Important at birth, it could be that these infants are more at rlsk to develop a clinical relevant witamin $K$ deflcliency after blrth.

Infants born of mothers with convulslve disorders, who have been recelving antlconvulsant therapy are llkely to develop a vitamin $k$ defliclency ( 80 ). To prevent thls compllcatlon oral vitamin $K$ should be administered to the mother for the last two months of pregnancy $(81)$. There Is no doubt that these infants should be given vitamin $K$ as soon as possible after dellivery. In the study of Shapiro (79) an Incidence as $\mathrm{hlgh}$ as 25\% of detectable descarboxyprothrombln has been found in these group of infants. 
Infants born to women taklng rlfamp in and isonlazld dur Ing prognancy may also be at risk for early haemorrhaglc dilsease of the newborn $(82)$.

4c. The siltuation after blrth

The situation after birth is more compl laated. Most studles are based on clotting activity assays of prothrombln or modiflcations of the prothrombin time. In none of the studles descarboxyprothromblin has been measured in a sufficlent number of infants. Van Doorm (75) found in 5 samples obtained on the third day of 11 fe of normal newborns no evidence for the presence of descarboxyprothrombin. Many problems are encountered In studying coagulation abnormallities in newborns in the postnatal perlod, such as relatively large amounts of blood required and the skll necessary to perform a clean venapuncture. As the newborn blood appears to be more susceptlible for in vitro proteolysis, appropriate inhlbitors should be present and the amount of the antlcoagulant should be corrected for the elevated haematocrit often found in newborns in the first week of life.

In many studies these important features are not mentloned. Howaver, also in studles that fulfil these crlterla, a remarkable broad normal range of the values is found. In one study several coagulation and flbrinolytic paraneters were measured using micromethods and chromogenlc substrates to obtaln normal values in the first week of life in a population of dutch newborns (83). In this study a gradual increase of prothrombin levels and an unexplained decline of factor $X$ levels was found. These results, were not influenced by the administration of vitamin K. A gradual increase of prothrombin levels after birth has al so been descrlbed by other authors $(84,70)$. According to Aballl (85) however, a remarkable decrease of the vitamin $k$ dependent factors is present in most newborns by two to three days of age, rising later in the first week of life secondary to Increased oral intake and posslble production of vitamin $K$ by the Infants' newly-obtalned colonic microflora. It was also clalmed that this "postnatal depresslon" can be largely ellminated if the infant recelves vitamin $k$. A number of authors have also found a signiflcant higher prothrombin level in the flirst days of Ite of Infants that had been given vitam In $K$. The favourable effect of vitamln $K$ prophylaxls was clalmed by a number of authors 185,86 , 87,88). However, the administration of vitamin $k$ to newborns did not result in differences with regard to bleoding problems in studies of other authors $(89,90)$;

This has been In part explalned by "Immaturlty" or "defective" hepatlc proteins synthesis $(91 \%$. This hypothesis can be challenged by the well known observation that other coagulation protelns, produced by the Iliver, which are not vitamin K-dependent, such as factor $v$ and fibrinogen, are Ithlin the normal adult range in term infants as well as in premature infants $(92)$. 
Recently an Increasling number of case reports has been published to emphasllze the resurgence of the haemorrhaglc dlsease of the newborn (HDN). In 1952 Dam noted that this dlsease ocurred more often in breast fed Infants (93). Thls was conflimed by other authors $(94,87,95)$. It was observed that HDN accurred almost excluslvelly in breast fed infants. Several reasons can be glven for the resurgence of HDN in the last five years. First, in recent years there has been a progressive increase in the proportion of bables breast-fed for at least the first two weeks of IIfe $(38,96)$. The vitamin $k_{1}$ content of human mllk is around one-fourth

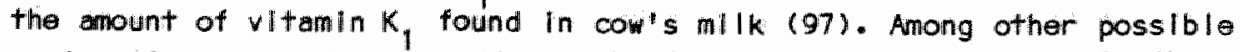
explanatlons are: breast milk contalns an $\|$ nhlbltor to vitamin $k$ or prothrombin, or the intestinal flora of breast-fed lnfants is less active in producling vitamin $k$ than the fllore of formula-fed infants (95). It is well established that the Intestinal flora and stool pH of breast-fed infants differs signlflcantly from that of infants fed with cow's mllk. In breast-fed Infants $79 \%$ of the fecal bacterla are Lactobaclllus blfidus and the stool pH is 5.5. The stools of cow's mlik-fed Infants show a more mixed flora Including Lactobacllius blfidus, Escherichla coll, Enterobacter and staphyllococcus aureus. The breast-fed infant lacks a signlflcant population of witamin $\mathrm{K}$ produclng bacterla; such as Escherlchlla collt and Staphylococcus aureus (98).

\section{Concllus lons and recommendations}

We conclude that the administration of vitam In $k$ at birth to healthy full term Infants is only indlcated when the mother is vitamin $K$ deflelent (or when this is suspected), for instance resulting from fat absorption disturbances, lenghty use of antiblatlcs, malnutrition and if the mother has used drugs with a known ant $|-v| t a m i n k$ effect such as the coumar in derlvatives or antl convulsives.

It may be consldered to adminlster vitamin $K$ allso to infants born of hypertensive or dlabetic mothers, to infants born after a compllcated dellivery and to linfants with infectious compllications and resplratory distress syndrome. Whether all infants small for gestatlonal age and premature Infants should be glven viltamin $K$ prophylaxls remains to be ostabllshed. Other woll deflned rlsk groups of infants who should recelve $v i t a m i n k$ prophyllaxis include: Infants who requile total parenteral nutrition or prolonged Intravenous therapy, Infants who have chronlc diarrhoea, cystic flbrosls or blllary atresla or other diseases known to be associated with a malabsorption of dietary vitamin $K$ and Intants recelving antliblotics or other drugs known to interfere elther Wth the vitamin K-producing Intestinal flora, the absorption of vitamin $K$ from the intestine, the transport of witamin $K$ to the llver or the avallablility of vitamin $K$ in the hepatocyte. Vitamin $K$ prophylaxls at blrth as well as in the pastnatal perlod is strongly propagated, 
especlally In the IIterature from the United States for all newborns, especially those exclusively fed with human millk. In The Netherlands a clinical relevant vitamin $K$ deflclency in newborns is very rare. Therefore we do not recommend the routinely use of vltanin $k$ prophylaxis for all newborns. However, witamin $K$ prophylaxis should be consldered especlally in breastfed Infants, when additlonal risk factors are prosent.

\section{References}

1. Dam, H. The ant Ihaemorrhaglc vitamin of the chlck. Blochem. J. 29, 1273 (1935)

2. Campbell, M.A., Link, K.P. Haemorrhagic disease in cattle. J. Blol. Chem. 138, 21 (1941)

3a. Hernker, H.C., Veltkamp, J.J., Hensen, A., Loellger, E.A. Nature of prothrombin synthesis. Preprothrombinemla in witamin $K$ deflelency. Nature 200, 589 (1963)

3b. Hemker, H.C., Veltkamp, J.J., Loeliger, E.A. Kinetlic aspects of the interaction of blood clotting enzymes. Thromb. Dlathes. Haemorrh. 19, 346 (1968)

4. Stenflo, J. Dlcumaral-induced prothrombin in bovine plasma. Acta Chem. Scand. 24, 3762 (1970)

5. Nelsestuen, G.L., Suttle, J.W. The purlflication and propertles of an abnormal prothrombin proteln produced by dicumaral treated cows. Blochemistry 11,4961 (1972)

6. Stenflo, J., Fernllund, P., Egan, W., Roepstorff, P. VItamln K-dependent modiflcations of glutamic acld residues in prothrombin. Proc. Natl. Acad. Scl. USA 71, 2730 (1974)

7. Nelsestuen, G.L., Zytkovlcs, T.H., Howard, J.B. The mode of action of vitam In K-Indentiflcation of gama-carboxyglutamic acid as a component of prothrombln. J. Blol. Chem. 249,6347 (1974)

8. Suttle, J.W., Jackson, C.M. Carboxylatad Ca-binding protelns and vitamiln K. Physlol. Rev. 57, 1 (1977)

9. Tuan, R. Vitamin K-dependent y-glutamyl carboxylase activity in the chlck embryonlc chorloallantolc membrane. J. Blol. Chem. 245, 1356 (1979)

10. Gallop, P.M., Llan, J.B., Haulschkal, P.V. Carboxylated Ca-blinding proteins and vitamin K. N. Engl. J. Med. 302, 1460 (1980)

11. Vermeer, C. The vitamin K-dependent carboxyllation reaction. Moll. Cell. Blochen. 61,17 (1984)

12. Lindhout, M.J., Kop-Klaasen, B.H.M., Reekers, P.P.M. and Henker, H.C. Demonstration of three protelns induced by vitamin $K$ absence In cows. J. Mol. Mad. 148, 140 (1976)

13. Whittion, D.S., Sadowskl, J.A., Suttio, J.W. Mechanism of coumarln action: significance of vitamln $k$ epoxlde reductase inhlbition. Blochemistry 17, 1371 (1978) 
14. Frladman, P.A. Shla, M.A., Gellop, P.H. and Grlep, A.E. Witamin $K$-dependent $Y$-carbon hydrogen bond cleavage and the non mandatory concurrent carboxylation of peptide bound glutamic acld residues. Proc. Natl. Acad. SCll. USA 76, 3126 (1979)

15. Larson, A.E., Frledman, P.A., Suttle, J.W. Stolchlometry of carboxylation and vitamin K 2,3-epoxlde formation. J. Blol. Chem. 256, $11032(1981)$

16. De Metz, M*, Soute, B.A.M., Henker, H.C., Fokkens, R., Lugtenburg, J., Vermeer, C. Studies on the mechanism of the vitamin K-dependent carboxylation reaction. J. Blol. Chem. 257, 5413 (1982)

17. Vermeer, C., Hendr Hx, H., Daemen, H. Vitamin K-dependent carboxylase from non-hepatlc tissues. FEBS Lett 148, 317 (1982)

18. Vermeer, C., Uirlch, M. Vitamin K-dependent carboxylase in horse IIver, spleen and kldney. Thrombos. Res. 28, 171 (1982)

19. L.lan, J.B., Frledman, P.A. The vitamin K-dependent synthesis of gama-cerboxyglutamic acld by bone microsomes. J. Biol. Chem. 253, 6623 (1978)

20. Esmon, C.T. and Owen, W.G. Identiflcation of an endothellal cell cofactor for thrombin catalyzed activation of protein C. Proc. Natl. Acad. Scl. USA 78, 2249 (1981)

21. Marlar, R.A., Klelss, A.J., Griffin, J.H. Mechanlsm of action of human actlvated protein C. Blood 59, 1067 (1982).

22. Comp, P.C., Esmon, C.T. Generation of flbrinolytic activity by Infusion of actlvated protelin C Into dogs. J. Clini. Invest. 68, 1221 (1981)

23. Comp, P.C., Nixon, R.R., Cooper, M.R. and Esmon, C.T. Famllial proteln $S$ deflelency is assoclated with recurrent thrombosis. J. Clin. Invest. $74,2082(1984)$

24. Broekmans, A.W., Veltkamp, J.J., Bertina, R.M. Congenltal protein C deflclency and venous thromboembollsm. N. Engl. J. of Med. 309, 340 (1983)

25. Blever, W.A., SkInner, A.L. Fatal neonatal haemorrhage after maternal ant lconvulsant therapy. JAMA 235, 626 (1976)

26. Stevenson, R.E., Burton, M., Fenlanto, G.J. Hazards of oral antlcoagullants dur ing pregnancy. JAMA 243, 1549 (1980)

27. Goldman, W. I. and Amadio, P. Vitamin $K$ deficlency atter the nowborn perlod. Padlatrles 44,745 (1980)

28. Keenan, W.J., Jewett, T., Glueck, W.l. Role of feeding and witamin $K$ in hypoprothrambinemla of the newborn. Am. J. Dis. Child. 121, 271 (1971)

29. Lorber, J., LIIleyman, J.S. and Pelle, E.B. Acute Infantlle thrombocytosis and vitamin K-deflclency assoclated with Intracranlal haemorrhage. Arch. Dis. Chllld. 54, 471 (1979)

30. Bhancet, P., Tuchlnda, S., Wathlrat, P. A bleeding syndrome in intants due to acquilrod prothrombin complex deflclency. Pedlatr. 16, 992 (1977)

31. PIneo, G.F., Gallus, A.S., HIrsch, J. Unexpected vitamin K deflclency in hospltallzed patients. Can. Med. Assoc. J. 109, 880 (1970) 
32. Nammacher; M*A., WIlltemIn, M*, Hartmann, J.R. Vitamin $K$ deflclency in infants beyond the meonatal perlod. J. Pedlatr. 76,549 (1970)

33. Matoh, Y. Plasma prothrombin in Infantlle dlarrhoea. Ann. J. Dls. Chlld. 80, 944 (1950)

34. Daum, F., Silverberg, M. in Lebenthal E. (ed). Effect of congenital anomalles of the gastrointestinal tract on infant nutrition. Textbook of Gastro-enterology and Nutrition in Infancy. New York, Raven Press. (1981)

35. Carpentlere, U. "Gustvason, J.L., Waggard, M.E. Misdlagnosls of neglect in a chlld with a bleeding disorder and cystic fibrosis. South Med. J. 71,854 (1978)

36. Latimer, J.S., Sharp, H.L. $\alpha$-antitrypsin defliclency in chlldhood. Curr. Prabl. Pedlatr. 11, 1 (1980)

37. Caballero, F.M*, Buchanan, G.R. Abetalipoprotelnemla presenting as severe vitamin K deflclency. Pedlatrles 65, 161 (1980)

38. MCNInch, A.W., Orme, R.L., Trlpp, J.H. Haemorrhagle disease of the newborn returns. Lancet 1, 1089 (1983)

39. Shearer, M.J., Rahm, S., Barkhan, P., Stlmmler, L. Plasma vitamin K, in mothers and their newborn bables. Lancet 11, 460 (1982)

40. Hamulyák, K. "z de Boer, M., Thljssen, H., Vermeer, C. The placental transport of I HIVItamin K, in rats. Thromb. Haemost. 54(1) 204 (1985)

41. Fuj Imura, Y., Nimura, Y., Knoshita, S., Yoshloka, A., Kitawakl, K., Yoshloka, K., Takamyla, c. Studles on vitamin K-dependent factor deficlency during early chlldhood with speclal reference to prothrombin activity and antigen level. Haemostasls 11, 90 (1982)

42. Atkinson, P.A., Bradlow, B.A., Moull neaux, J.D., Walker, N.P. J. of Pedlatr. Acarboxy prothrombin in cord plasma from normal neonates. Gastroent. and Nutr. 3, 450 (1984)

43. Townsend, C.W. Arch. The haemorrhaglic dlsease of the newborn. Pedlatr. 11.559 (1894)

44. Q"Connor. M.E., Livingstone, D.S., Hannah, J., Wliklins, D. Vltamin K defliclency and breast-feeding. Am. J. Dis. Child. 137, 602 (1983)

45. Muntean, W. WItam In K-Mangel bel Neugeborenan. Wlener KIIn. Wschr. 95, $1: 1:(1983)$

46. Bhanchet, P., Kashemensent, C. A bleeding syndrome in intants: acquiled prothrombin complex deficlency of unknown etlology. South East Aslan $\mathrm{J}$. Trop. Mod. Publl. Heth. 6, 4:592 (1975)

47. Nakayama, K. Etlology of vitamin $K$ deflclency in infants. Perlnat. Med. (Japanese) 12, 1029 (1982)

48. Gladek, B.E., Buchanan, G.R. The bleeding neonate. Pedlatrles 58, $548(1976)$

49. Nalman, J.L. Clotting and bleeding in cyanotllc congenltal heart dlsease. J. of Pediatrlics 76, 333 (1970)

50. Kollen, F., Loelliger. E.A., Duckert, F. Experiments on a new clotting factor (factor V1l). Acta Haemat. 6, 1 (1951) 
51. Laurell, C.B. Quantltative estimation of protelins by electrophores is in agarose gel containing antlbodles. Anal. Blachem. 15, 45 (1966)

52. Bas, B.M. Studies on coagulasemthrombin. Thesis, Lelden (1975)

53. Bas, B.M., Muller, A.D., Voort-Beelen, J.M. The rellation between staphylocoagullase reacting factor and protteins Induced by $v i t a m i n k$ antagonlsts. J. Mol. Med. 1, 65 (1975)

54. Laurell, C.B. Antlgen-antlbody crossed electrophoresis. Anal. Bloch. $10,358(1965)$

55. Furle, B. Comparison on the native prothrombin antigen and the protthrombin. time for monltoring oral antlicoagulant therapy. Blood, $64: 2,445(1984)$

56. Motobare, K. Severe vltamin $K$ deficlency in breast-fed infants. J. of Pedlatrlcs 105, 943 (1984)

57. van Doorm, J.M. De zogenaamde vitamine $K$ deficlëntle van de pasgeborene, Thesis, Gronlingen (1976)

58. Frlck, P.G., Rledler, G., Brggll, H. Dose response and minlmal requlrement for vitamin $K$ in man. J. Appl. Physlol. 23, 387 (1967)

59. Langenberg, J.P. TJaden, U.R. Improved method for the determination of vitamin KO In human plasma with electrofluorimetric reaction detection. J. Chromatog. 289 (1983)

60. Duello, T.J., Matschlner, J.T. J. Nutrition 102, 331 (1972)

61. Suzukl, S. Wirkung von Vitamin $K_{2}$ auf die Blutgerlnnung belm Neugeborenen. Z. Kinderhellk 115, 261 (1973)

62. Hauschke, P.V., Llan, J.B., Gallop, P.M. Vittamin K and minerallzation. Trends in Blochem. Soc. 78 (1978)

63. Blanchard, R.A., Furle, B.C., Barnett, J., Peck, C., Fave, K., Jacobs, M., de Furlo, L., Furle, B. VitamIn K defllclency in newborns and thelr mothers. Thrombosis and Haenostasis $54(1) 226,1985$

64. Helk Inhelno, R. Coagulation studles with fetal blood. Blol. Neonat.7, $319(1964)$

65. Fortune, W.A., Cox, J.R. Fetal factor VIII and $I x$ levels in early pregnancy and their slgniflcance in prenatal diagnosis. Acta Haem. 49, $314 \cdot(1973)$

66. Holmberg, L., Hendr lkson, P., Ekelund, H., Astedl, B. Coagulation in the human fotus: comparl son w th term newborn Infants. J. of Pedlatrlcs 85, $860(1974)$

67. Mlbashan, R.S., Rodeck, C., Thorpston, J.k. e.a. Prenatal plasma assay of fatal factor VIII and factor IX. Br. J. of Haemat. 41, 611 (1979)

68. Terwlel, J.Ph., Valtkamp, J.J., Bertina, R.M., Mull ler, H.P. Coagulation factors $: n$ the human fetus of about 20 weeks of gestatlonal age. Br. J. of Heemat. 45, 641 (1980)

69. Forestler, F., Daffos, F., Rainant, N., Potron, G. Normal fetal haemostasls at mid trimester of pregnancy. Thrombosis and Haemostasis $54(1) 259$ (11985) 
70. Jensen, A.H., Josso, F., Zamet, P. et al. Evolutlon of blood clotting factor levels in premature infants during the first 10 days of life. Pediatric Res. 7. 538 (1973)

71. Hathaway, W.E., Bonnar, J. Perlnatal coagulatlon. In: Monographs in Neonatology, New York, Grune and Stratton, 27 (1978)

72. Barnard, D.R., Simnons, M.A., Hathaway, W.E. Coagulation studies in extremely premature infants. Pedlatrlc Res. 13, 1330 (1979)

73. Barnard, D.R. Inherited bleeding disorders in the nowborn Infant. Clinics in Per Inatology 11, 309 (1984)

74. van Doorm, J.H., Muller, A.D., Hemker, H.C. Heparin-like Inhlbitor, not vitamin $K$ defliclency in the newborn. Lancet | 852 (1977)

75. Gobel, U., Sonnerschein-Kosenow, S., Petrlich, C., van Von, H. WItamin K deflelency in newborn, Lancet $\| 187$ (1977)

76. Morl, P.G., Bisognl, C., Tonlinl, G.P. et al. Vitamin $K$ deficlency in newborn, Lancet 11188 (1977)

77. Malla, R.G., Preston, F.E., Mitchell, W.E. Evldence agalnst vitamin K deflelency in normal neonates. Thromb. Haemost. 44, 159 (1980)

78. Muntean, W., Peter, W., Rosanelll, K., Mutz, J.D. Immunologlc studles of prothromb in in newborns. Pediatrlc Res. 13, 1262 (1979)

79. Shaplro, A.D., Hulac, P., Jacobsen; L.J., Lane, P.A., Nauco-Johnson, M.J., Hathaway, W.E. Prevalence of vitamin K deflclency in newborn Infants: Influence of perlinatal risk factors. Thrombosis and Haemostasis $54(1)$ 125, (1985)

80. Mountaln, K.R., Hirsh, J., Gallus, A.S. Coagulation defect due to antlconvulsant drug treatment in pregnancy. Lancet 1265 (1970)

81. Selp. M. Effect of antleplleptic drugs in pregnancy on the fetus and newborn infant. Annals of Clin. Res. 5, 205 (1973)

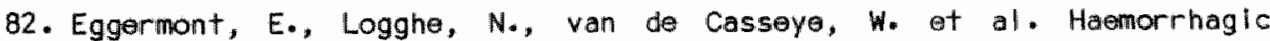
dilsease of the newborn in the offspring of rlfampin and Isonlazld treated mothers. Acta Paedr. Belg. 29, 87 (1976)

83. Peters, $M_{*}$ et al. Rapld mlcroanalysis of coagulation parameters by automated chromogenlc substrated methods, application in neanatal patients. Thromb. Res. 28, 773 (1982)

84. Andrew, M., Paes, B., Mllner, R., Johnston, M., Powers, P., Tollefson, D.N. Postnatal development of the coagulation system in the full term Infant. Thrombosis and Haemostasis $54(1) 259$ (1985)

85. Aballl, A.J., de Lamerens, S. Coagulation changes in the neonatal period and in the early infancy. Pediatric Clinlcs of North Amerlea 9, 785 (1962)

86. Nyegaard, K.K. Prophylactic and curative effect of vitamin $K$ in haemorrhaglc disease of the newborn. Acta Obstet. Gynaecol. Scand. 19, 361 (1939)

87. Sutherland, J.M., Quueck, H.l., Gleser, G. Haemorrhaglc disease of the newborn. An. I. of D/s. Chlld. 113, 524 (1967) 
86. Viett1, T.J., Murphy, T.P., James, J.A. et al. Observations on the prophylactic use of vitamin $K$ in the newborn infant. J. Pediatrles 56, $343(1960)$

89. Denton, R.L. Vitamin $K$ for the newborn? Pedlatr. Cllnles of North Amerlco B, 455 (1961)

90. McElfresh, A*E. Coagulation during the neonatal perlod. Am. J. Med. Scl. 242,771 (1961)

91. Schettini, F., de Mattla, D., Mantone, A. et al. Post natal development of factor II In man. Bllology of the neonate, 29, 82 (1976)

92. Sell, E.J., Corrlgan, J.J. Platelet counts, flbrlinogen concentrations and factor $V$ and factor VIII levels in healthy infants according to gestational age. J. of Pedlatr. 82, 1028 (1973)

93. Dam, H., Dygsve, H., Larsen, $H_{\text {. }}$ et al. The relation of vitamin $K$ deflclency to haemorrhagle disease of the newborn. Advances in Pedlatrlics, 5, 129 (1952)

94. Wehrling, K.W. Haemorrhage in the newborn and Vltamin $K$ prophylaxis. J. of Pedlatrles 61,868 (1962)

95. Keenan, W.J., Jewett, T., Gluck, H.I. Role of feeding and witamin K In hypoprothrombInemla of the newborn. Am. J. Dis. Child 121, 271 (1971)

96. Verlty, C.M. ot al. Vitamin $K$ deflclency causing infantile intracranlal haemorrhage after the neonatal perlod. Lancet $1: 1439$ (1983)

97. Haroon, Y.. Shearer, M.J., Rahlm, S. et al. The content of phylloqulnone, (vitamin $K_{1}$ ) in human milk and infant formula foods determined by hilgh-performance Ilquld chromatography. J. Nutr. 112, 1105 (1982)

98. Glbbons, R.J., Engle, L.P. Vitamin $K$ compounds in bacterla. Scleince 146,1307 (1964) 
CHAPTER 3

FIBRIN(OGEN) DEGRADATION PRODUCTS IN NEWBORN PLASMAS CAN CAUSE A FALSE INTERPRETATION OF THE PROLONGATION OF THE THROMBOTEST CLOTTING TIME

K. Hamulyák ${ }^{1}$, P.P. Devlliéé ${ }^{1}$, W. Nleuwenhulzen ${ }^{2}$, H.C. Hemker ${ }^{1}$

1 Dpt. of Blochemistry, Faculty of Medicine, University of Limburg, 2 Maastricht, The Nether lands

2 Gaublus Institute, TNO, Lelden, The Netherlands 
According to the ilterature, clotting inhibiting material is present in umbillcal cord plasmas of $67 \%$ of all healthy full ferm linfants as Judged from thrombotest dllution curves. We investigated 40 umbllical cord plasma samples, whlch were drawn under conditlons ith minlmize in vitro activation of the haemostatic mochanism.

In these samples, the prothrombin clotting activity (IIC) levels, using a one stage method, ranged from 28.8 - $73.7 \%$ as compared with adult normal plasma values $(100 \%)$. The mean value was $50.6 \% \pm 12.1$. There was no difference between the inhlbited (in the thrombotest dllution curve) and non-Inhibited group with regard to the prothromb in levels (11c).

The thrombotest clatting times ranged from $35.2-66.5 \sec (53.3+8.1)$. The correlation coefficlent ( $r$-value) between the thrombotest clotting times and the prothrombin (IIc) levels was -0.46 .

Using sensittive Immunoassays for flibrlin degradation products (XDP) and flbrinogen degradation products (FDP) based on monoclonal antlbodles, we found that no degradation products could be demonstrated in the nonInhlbIted group, whereas degradation products were found in the Inhiblted group.

The most striking finding was the presence of fibrlnogen degradation products. The prolongation of the thrombotest clotting time could be Imitated by adding small amounts of purlfled fibrinogen degradation product fragment $x$ to umblilical cord plasma with a normal thrombotest clotting time. We conclude that there is a poor correlation between the thrombotest clattling time and prothrombin activity (IIC) levels in newborns. This makes the thrombotest of less value in the assessment of the witamin $K$-dependent coagullation factors in umb ll lcal cord plasma. Furthermore, we conclude that this poor correlatlon can be explalned by the presence of small amounts of flbrin(ogen) degradation products, which are undetectable using conventional assays for FDP and/or XOP.

As utmost care was taken to avold proteolytlc breakdown in vitro, our findings most likely reflect an enhanced flbrinolgenollytlc actlvity in umblllcal cord plasma in vivo.

Thls could be due to an Increased tissue-plasminogen activator activity in umblll cal cord plasma. The enhanced tissue-type plasminagen activator (tPA) activity may be due to an enhanced release from the endothellal cells and/or a decireased inhibition by a recently dlscovered fast-acting Inhibltor of TPA.

\section{Introduction}

The vitamin K-dependent coagulation factors in full term, healthy newborns are at birth in the range of 20-60\% of the values found in adults (1). A vitamin $K$ deficlency can be held responsible for thls in only a minority of 
the cases $(2,9)$. Among the laboratory tests, often used in clinlcal practice, to obtaln an Impression of a deficlency, of the coagulation factors 11 , $W I \|$ and $X$ are Thrombotest and Normotest. Both reagents are commerclally avallable (Nyegaard, Oslo, Norway) and contaln BaSO 4 -adsorbed bovine plasma and a source of thromboplastin. The exact composition of these comerclal reagents has not been published.

The tests are varlants of the classical prothrombin time test in the presence of excess factor $V$ and flbrlnogen. Therefore, a possible deflclency of factor $v$ and/or fibrinogen is not measured in the thrombotest or normotest assay. The tests are also insensitive to a deflclency of factor $\| x$, because of the large amount of thromboplastlin, present. Moreower, a number of other factors, besides the amount of the coegulation factors 11 , $V I l$ and $X$, influence the clotting times. Relatively short thrombotest clotting times are found, when the blood samples are stored for more than 2-4 hours in glass tubes at low temperatures. This phenomenon is probably due to a factor XII dependent activation of factor VII (3) and Is especlally important In plasmas of women, using or al contraceptive drugs (4).

Relatively long thrombotest clotting times are found, whenever one of the coagulation factors $11, V \| I$ and $X$ becomes rate $\| \mathrm{imit} I \mathrm{ng}$, for Instance when one of these factors is congenltally deficlent or early in oral ant 1coagulant therapy with coumar in derlvatives. Other causes for relatively long thrombotest clotting times are for instance the presence of $a$ structurally abnormal factor $I X$ (Haemophilla $B_{M}$ ) (5), the presence in plasma of heparln, descarboxy-coagulation factor $X(6)$ and an excess of citrate (7). Descarboxy-coagulation factors $11, V \|$ and $X$ are found in plasma of vitamin $K$ deflclent patients and/or in the plasma of patlents using coumar In derlvatives as oral antlcoagulant therapy.

The Inhibitory effect of the descarboxy-factors on the thrombotest clotting time was described by Hemker et al for the first time (1963) and provided the basis for the modern concept of the mechanism of action of vitanin $k$ (a). It is not known, if this inhlbition has any pathophyslologlcal importance. In contrast, the inormotest is relatively insenslitive to the presence of descarboxy coagulation factors in plasma. In umblilical cord plasma, inhlibition of the thrombotest clatting time, defined as a difference of at least 5 seconds in the extrapolated "Infinite high" concentrations in the so called thrombotest dilution curve (see flgure 1) has been descr lbed in $67 \%$ of all normal full term healty newborns by van Doorm (9). This Inhibltion was not due to discrepancies between the Individual coagulation factors $11, V I 1$ and $X$ or the presence of descarboxycoagulation factors. Another explanation for the prolonged thrombotest clotting times could be the presence of fibrin(ogen) degradation products. However, using a conventional method for the determination of flbrlin(ogen) degradafion products, van Doorm could not demonstrate the presence of these products in umblllical cord plasma samples (9). Several other investigators have also reported negative results, provlded that the blood sampling and processing 


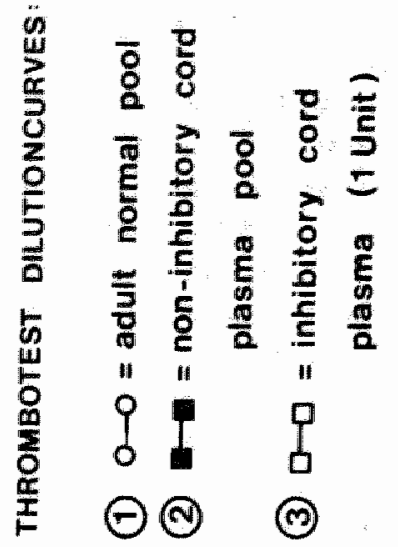

$\frac{w}{\frac{1}{4}}$

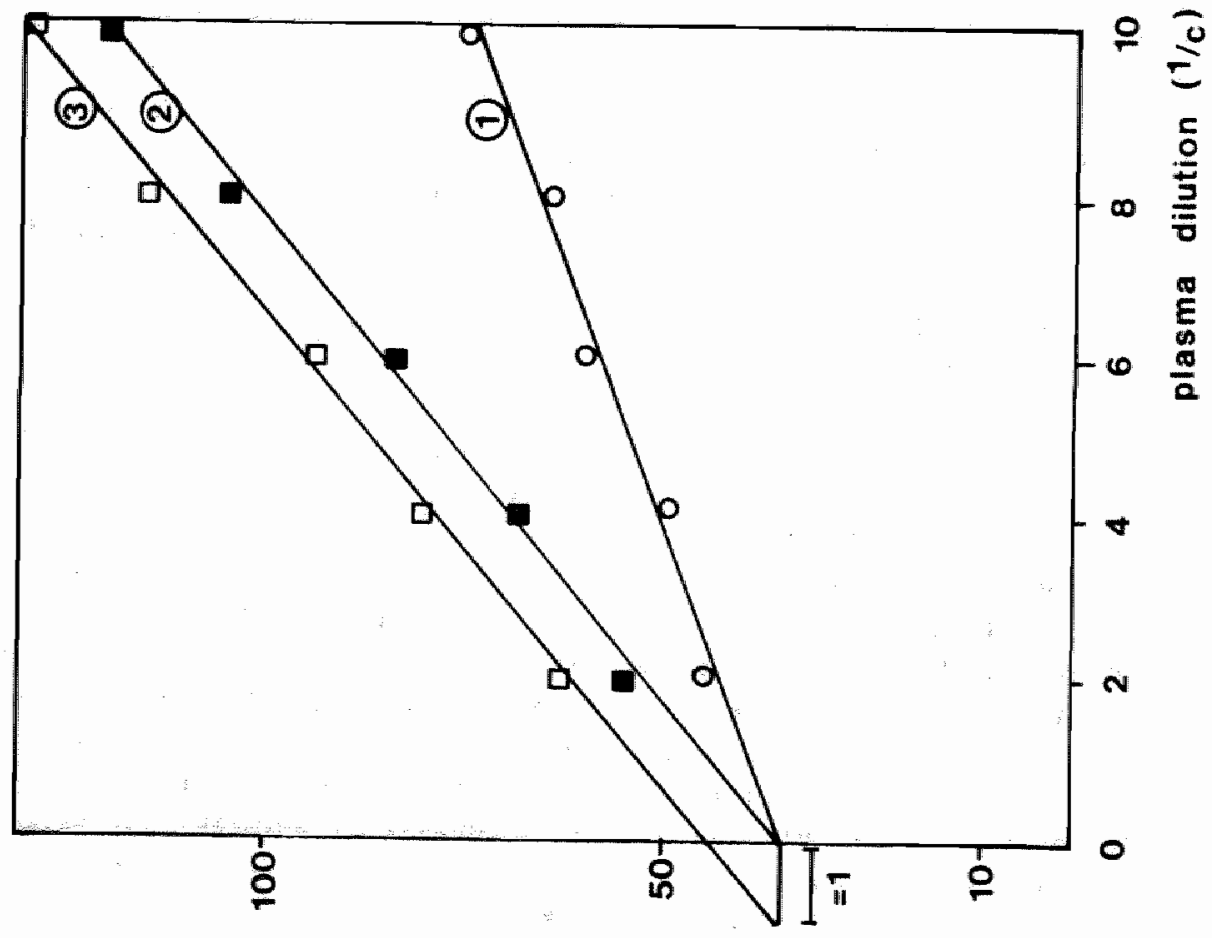

(Des) ${ }^{2}$ 
was adequate to avold In vitro activation of flbrino(genollys is $(10,11)$. No sifnificant differences have been reported between the Inhibited and mon-inhlbited group with regard to the levels of a number of protease Inhibltors such as $\alpha_{1}$-antitrypsin, $\alpha_{2}$-macroglobulin, $\alpha_{2}$-antlplasmin and ant thrombin 111 . These results were based on 1 munologlcal determinatlons (9).

Kirchhoff 112 ) found that the prolongation of the thrombotest clotting time was more pronounced in newborns delivered vla dlfflcult vaglnal dellverles than in newborns dell vered via Caesarean Sectlo.

on the basis of experlments with protam ine-neutrallzatlon and the fact that the actlion of the inhlbitor appeared to be dependent on the presence of antithromb in 1\|l, van Doorm suggested that the inhlbltor could be heparinIIke. In this thesis (chapter i) we have descrlbed that in individual umbllical cord plasmas heparin-llike activity is present only in $\frac{1}{2}-1$ of all cases and therefore cannot be the explanation for the prolongling effect on the thrombotest clotting time, found in $67 \%$ of all newborns. Notwithstanding the posslble complications in everyday practlice, Thrombotest and Normotest $t^{R}$ are widely used as a screening test for the amount of the vltamin $K$-dependent coagulation factors present and by some authors even recommended as a dlagnostic tool for a vitamin $k$ deficlency in newborns (13).

The aim of thls study was to assess the value of the thrombotest- and normotest cllotting time in defining the levels of the vitamin K-dependent coagulation factors in newborns and to investigate whether these tests can Indeed be used in clinical practice. In a prevlous study (14) we revaluated the so called fetal flibrinogen and found that the properties of fotal plasma, attrlbuted to fetal flbrlnogen could be mlmlcked by adding purlfied flibrinogen fragment $x$ to pur ifled fetal and adult flbrinogen. No differences could be demonstrated between purlfled adult and fetal flibrlnogen. We Investlgated the possiblility that flbrin(ogen) degradation products could contribute to the prolongation of the thrombotest clotting time in newborns. We used new sensltive methods for the determination of (librin(agen) degradation products directly in plasma, 1.e. enzyme 1 mmuno assays (EIA's) based on monoclonal antibodles directed against new antigenlo sites, which become exposed upon the protealytlc breakdown of fibrlin(ogen). These ElA's wlll be descrllbed elsewhere and are more sensitlive than the assays currently avallable. The lower detection $1.1 \mathrm{mit}$ is 1 ess than $0.25 \mu \mathrm{g} / \mathrm{ml}$.

Mater lals and methods

We investigated 40 umbll licall cord plasmas of healthy full term newborns. No vitamin $K$ had been administered to the mother or the newborns, nor any medication, known to influence the normal haemostatlc mechanism. In all cases, the apgar score at 1 ' was more than 7 and the plasma pH above 7.2. \#med lately after birth the umbllical cord was clamped and blood drawn by a 
clean puncture of the umbllical veln. After discarding the first $5 \mathrm{ml}, 9$ volunes of blaod were lxed (In a propylene tube) with 1 volume of an antlcoagulant mixture $10.3 \mathrm{M}$ hydroxyethylplperazline ethane sulfonic acld (Hepes), $0.1 \mathrm{M}$ disodium cltrate dihydrate, $15 \mathrm{mM}$ sodium azide and $1000 \mathrm{KIE}$ trasyloll $/ \mathrm{ml})$. This mixture effectlvely prevents in witro fibrinolgeno lysis and in vitro activation of factor Vil. Platelet poor plasma was obtained by centrifugation at $3000 \times 9$ for 151 minutes and rendered platelet free by centrifugation at $20000 \times \mathrm{g}$ for $30^{\prime}$ at $4{ }^{\circ} \mathrm{C}$. The samples. were frozen imadiately at $-800^{\circ}$ in allquots of $1 \mathrm{ml}$. Plasma of 10 adult donors were prepared in the same why and equal volumes mixed to serve as a "control normal pool'. Thrombotest" and Normotest" reagents were obtal ned from Nyegaard, Oslo, Norway.

The assays were performed exactly as Indlcated in the manufacturers prescription. Thrombotest dllution curves were made by plottling the thrombotest clatting times $(Y$-axis) agalnst the corresponding dilution of plasma $(x$-axis). These curves have been shown to be $\|$ inear (15). Plasmas were diluted $1 / 2,1 / 4,1 / 6,1 / 8$ and $1 / 10$ In Michael is buffer (Na-veronal $0.15 \mathrm{M}$, Na-cltrate $0.109 \mathrm{M}, \mathrm{NaCl} 0.15 \mathrm{M}, \mathrm{pH} 7.4)$ in plastlic tubes Immediately before they were tested and kept at room temperature. The Thrombotest reagent was dissolved In $11 \mathrm{ml} 3.2 \mathrm{mM} \mathrm{CaCl}$. in each test tube $0.25 \mathrm{~m}$ l Thrombotest -reagent was prewarmed at $37^{\circ} \mathrm{C}$. Clotting was inlitiated by adding $0.05 \mathrm{ml}$ plasma dllution to the test tube. All measurements were performed in duplo within $30 \mathrm{minutes}$ after the preparatlon of the dllutions.

At the intersection point in the $Y$-axis the concentration of the coagulation factors is "InfInite high". In all cases the point of elntersection on the $Y$-axis should be the same, provided that no inhlibltors are present In the sample and that there are no major discrepancles between the levels of the Individual vitamin K-dependent coagulation factors. If Inhibiting materlal is present, the degree of inhibltion can be expressed in unlts as Indlcated in flgure 1. The slope of the curve is indicative for the amount of the coagulation factors $11, V I 1$ and $X$ present in the sample. The amount of factor 11 was determined with a one stage method with human thromboplastin and human factor \|l deflclent plasma (16), usling a computer program based on the clotting times of elght dillutlons of adult normal pool plasma. Flbrincogen degradation products were determined in serum using the conventlonal test kit of Wellcome and also directly in plasma using new enzyme Immuno assays (EIA's) based on monoclonal antlbodles. Detalls of the ElA's for the total flbrln (XDP) plus fibrinogen (FDP) degradation products (XPP $p /$ lus FDP) and flbrlinogen degradation products (FDP) separately wlll be published elsewhere (manuscrlpts submitted). For these two assays a monoclonal antlbody, speclfic for degradation products of flbrlin and flibrlinogen was used as catching antibody. FoP was quantlifled with a horse-radlsh peroxydase (HRP) conjugate of a monoclonal antlbody directed agalnst flbrinopeptide A contalning fibrinogen fragments as tag (Blood, in 
press). The total of FDP and XDP was quantlfled with a HRP conjugate of polyclonall IgG"s directed against flbrinogen, flbrlin, $X, Y, D, E$ and $A \alpha, B \beta$ and $\gamma$ chains. The flbrin degradation products (XPD) assay was carrled out as descrlbed by Rylatt (17). Materlals for the XDP assay were bought from Mablo, Brisbane, Australla.

Purlfled flbrin degradation products $X$ (17) $Y$ (18) and $D-D$ (19) were prepared as descrlbed previously. They were added in small amounts to adult normal plasma and the non-Imhlblted pool of umblilical cord plasma.

Results

In table I the mean values, range and standard devlatlons are glven of the thrombotest clotting times, the normotest clotting times and the one stage factor II (I/C) determinations. The lic levels are expressed as a percentage compared wth the aduit normal plasma pool (100\%). The clotting times are given in seconds and represent the values found when non diluted plasmas were used.

TABLE I

\begin{tabular}{|c|c|c|c|}
\hline assay & $N$ & mean value and SD & range \\
\hline thrombatest clotting time & 40 & $53.3^{\prime \prime}+$ & $35.2-66.5$ \\
\hline normotest clotting time & 40 & $32.81 \overline{+} 4.7$ & $25.3-44.1$ \\
\hline factor II (one stage) & 40 & $50.6 \% \pm 12.2$ & $28.8-73.7$ \\
\hline
\end{tabular}

The correlation coefflclent ( $r$-value) betwen the thrombotest clotting timg and the factor Ilc levels was -0.46 , between the normotest clotting time and the factor lic levels -0.70 , Indlcating that especially the thrombotest clotting time does not glve rellable information on the level of the vitamin $\mathbb{K}$-dependent coagulation factor 11 . This could be due to the fact that in $67 \%$ of all umblllcal cord plasmas an inhibltor is found in thrombotest dilution curves (9). Fibrin(ogen) degradation products could not be demonstrated in any of the samples, using the test kit of wellcome. The sensitivity of this method, however, Is not very high. The detection $1 / \mathrm{mit}$ is around $10 \mu \mathrm{g} / \mathrm{ml}$. Moreover, sone high molecular welght degradation products are thrombin clottable and will therefore not be measured in the conventional assay, whlch makes use of serum.

Recently (J. Koopman et al. and P.W. Koppert et al, manuscripts submitted) sensitive EIA's have been developed for the quant1+1cation of the total of fibrin plus flbrinogen degradation products (FDP + XDP), and of fibrinogen degradation products (FDP). The assay of XDP was performed as descrlbed by Rylatt (17). With these EIA's we determined the levels of FDP + XDP, FDP 
and $x p^{p}$ in 6 inhlblted and 6 nom-Inhbited umbllical cord plasms samplos and aduit normal pool plasma.

in the non-Inhiblted samples no flbrin(ogen) degradation products could be detected, whereas in the inhiblted samples small amounts of fibrin(ogen) degradation products were present. These results are summarlzed in table 11. The fibrla(ogen) degradation products are expressed as lig fibrinogen equivalents.

TABLE \|

\begin{tabular}{ccccc}
\hline sample & $\begin{array}{l}\text { degree of } \\
\text { Inhlbition (U) }\end{array}$ & FDP + XDP & FDP & XDP \\
\hline 1 & 0.4 & 1.9 & 0.7 & $<0.25$ \\
2 & 0.5 & 5.8 & 2.0 & 2.2 \\
3 & 0.5 & 0.7 & $<0.25$ & $<0.25$ \\
4 & 1.3 & 12.8 & 3.7 & 4.6 \\
5 & 0.3 & 2.2 & 0.5 & $<0.25$ \\
6 & 0.3 & 1.8 & $<0.25$ & $<0.25$ \\
non Inhibited & 0 & $<0.25$ & $<0.25$ & $<0.25$ \\
cord plasma & 0 & $<0.25$ & $<0.25$ & $<0.25$ \\
adult plasma & 0 & & & \\
\hline
\end{tabular}

In order to see, whether Inhibltion of the thrombotest dilution curve could be caused by degradatlon products, we added small amounts of purlfled degradation products $X, Y$ and $D \rightarrow D$ to adult normal pool pllasma and non-Inhlbited umblllcal cord plasma.

The addition of fibrinogen fragnent $x$ to adult plasma even in relatively high concentratlions gave only a slight prolongation of the thrombotest clotting time. In non-Inhlblted umblilcal cord plasma, however, a more pronounced prolongation was found, at a final concentration of fragment $X$ of 2.6 and $26 \mu \mathrm{g} / \mathrm{ml}$. The results are given $\mathrm{in}$ flgure 2 and 3 . Additlon of the fragments $Y$ and $D-D$ in these low concentrations did not affect the thrombotest clot+ling time of adult or non-lnhlblted umblllcal cord plasma.

\section{DIscussion}

Recently, the discussion in the llterature on the prevalence of a witamin $K$ deflclency in newborns has regalned much attention. A number of case reports has been publlished, showing evidence of a vitamin $K$ deflclency, especially after the first few days of 11 fe $(21,22)$. This deflelency has been attrlbuted to changes in the food pattern (relative increase in breast fed infants sinco 1980) and a poorly developed colonization of the gut with vitamin $k_{2}$ producling bacterlla $(21)$. 


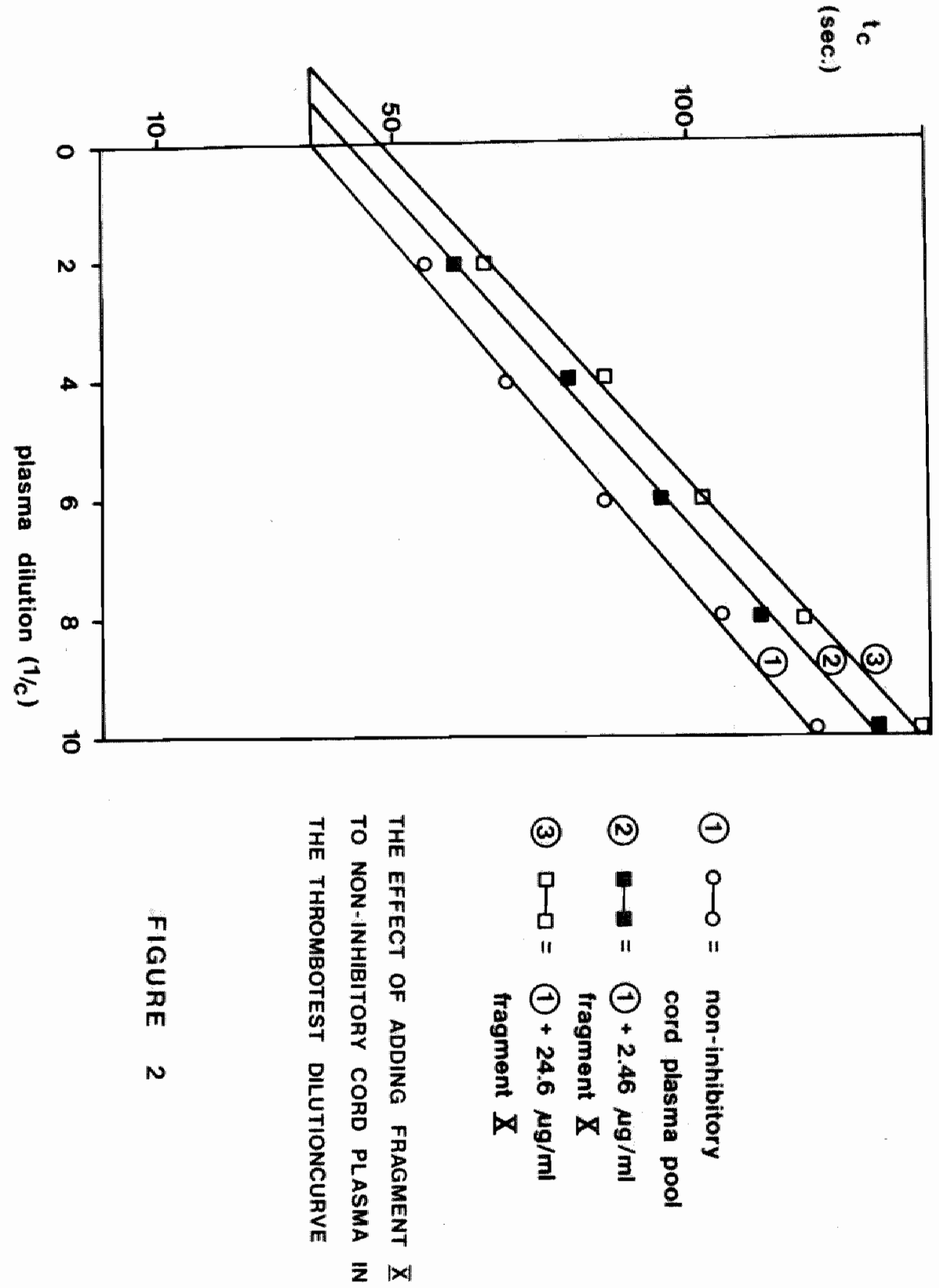




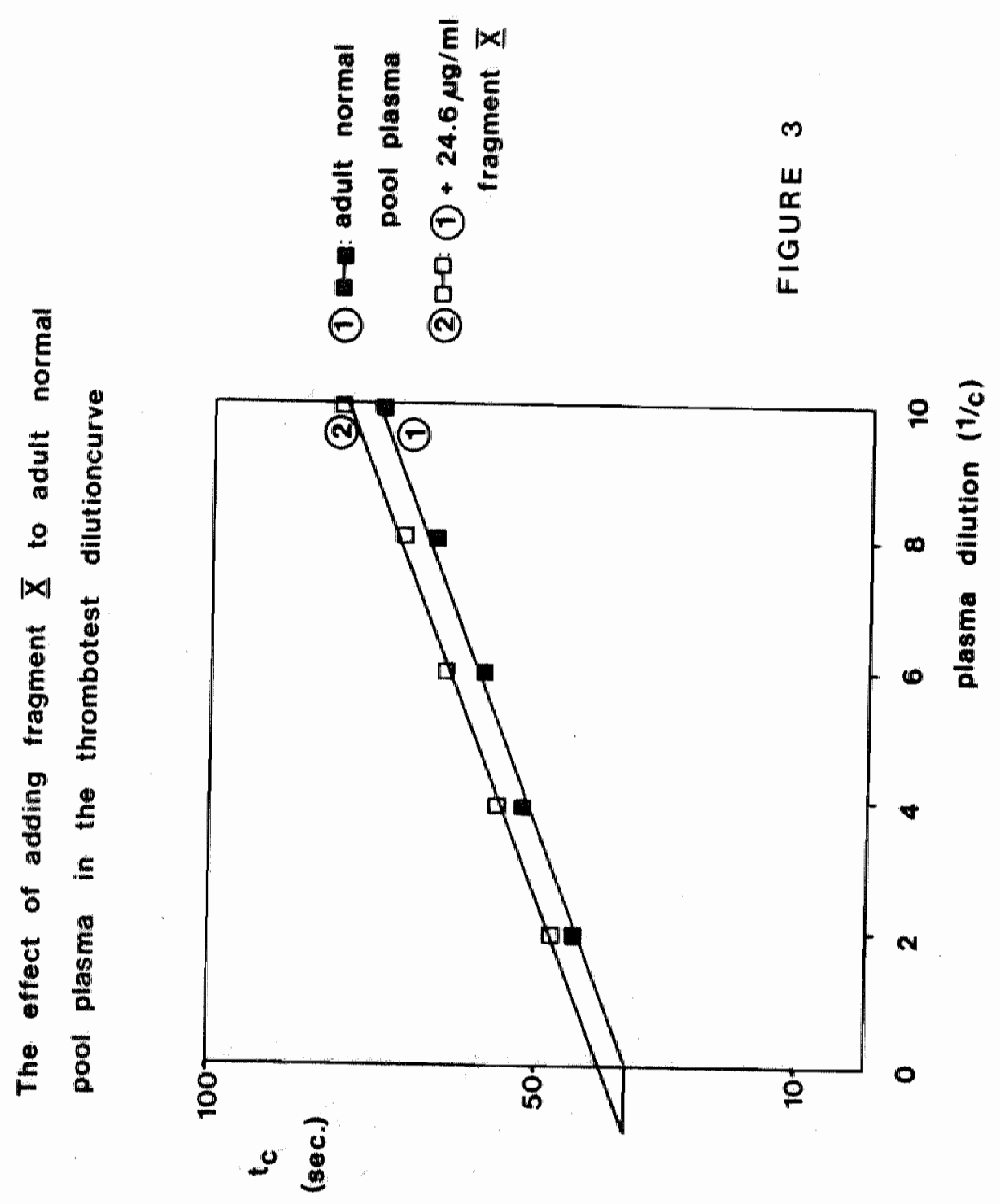


At blrth, however, the vast majorlty of all normal newborns appears not to be vitamin $K$ deficlent $(2,9)$, in spite of the fact that the vitamin $K$-dependent coagulation factors are around $50 \%$ of the values found in adults (1). In our oplninon, the administration of vitamin $k$ to newborns should be based on an adequate laboratory dlagnosis of vitamin $k$ deficiency. This Implles first of all adequate wenapuncture and processing of the blood sample. In many routine clinlcal laboratorles a prothrombln time test or one of its varlants 1.e. the thrombotest and normotest are used to assess the levels of the vitamin $K$-dependent coagulation factors. Several factors are known to cause a fallse prolongation of the prothrombln time and its varlants. One of these is an excess of ciltrate in the case of an increased haematocr $1+(7)$.

Neonatal polycythemla is reported to occur in $10 \%$ of all newborns in the first week of 11 fe (23). In these cases a correction should be made for the amount of citrate used in the antlcoagulant mixture in whlich the blood is coll lected.

In our umblilical cord samples the haematocir It values ranged from 0.44 0.54 and no haematocr It differences were observed between the inhiblted and non-Inhlblted group. In this study, we have provlded data to show that the thrombotest clotting time cannot be used as a rellable predlictor to assess the vitamin $K$ status of newborns. There was a poor correlation between the thrombotest clotting times and the prothrombin clotting activity (1/c) levels in umbillical cord plasma samples. This is probably due to an inhlbitory factor of the thrombotest clotting time present in $67 \%$ of the cases.

Using sensitive ElA's, recently developed by the Gaublus Institute (Lelden, The Netherlands) we have demonstrated that fibrin(ogen) degradation products are present in umblilical cord plasmas, showing inhibltion as Judged from the thrombotest dilution curve, whereas they could not be detected in any of the samples of the non-inhlblted group. Using conventlonal assays we were unable to detect these degradation products in umbllical cord blood. A number of investigators were unablo to demonstrete flbrin(ogen) degradation products in serum prepared from umbllical cord blood $(10,11)$. This can be due to the fact that the conventlonal method is not sensitive enough or to the possibllity that high molecular welght florlin(ogen) degradation products are partlally thronbin clottable and will therefore not contribute to the amount of fibrinogen rellated antigen determined in the conventional method, since the latter assesses fibrinogen related antigen recovered in serum after complete clotting induced by thrombin and thromboplastin in the presence of trasylol.

The most striking finding was the presence of flibrlinogen degradatlon products in our samples. Thls is only rarely found in disease states with primary fibrinogenolysis or with therapy ith thrombolytlic agents such as streptokinase. As we took care to minimize proteolysis lin vitro, we foel that our data reflect an enhanced fibrinolgenol lytlc activity in umb I llcal 
cord blood in vivo. We were also able to induce the prolangation of the thrombotest clotting time by adding small anounts of puritled flbrinogen fragment $K$ to the non-inhlbited umb IIlcal cord plasma and adult normal pool plasma. The ffect of the addition of flbrinogen fragment $x$ appeared to be more pronounced with unbllical cord plesme than with adult plasma. He conclude that the prollongation of the thrombotest clotting time in newborns is only partlally due to low levels of the vitamin $k$-dependent coagullation factors $11, Y 11$ and $X$ and that the results of thls test should therefore not be used as evidence for a vitanln $k$ deflclency. Too many factors, beslides the levels of the vltamin $K$-dependent coagulation factors, Influence the results of this screening coagulation assay. As shown here, also flibrinogen degradation products contribute to the prolonglation of the thrombotest clotting time. It 111 be clear, that the $11 \mathrm{~m} l$ tation of the use of the thrombotest is even more pronounced, when the blood samples are drawn not carefully and when adequate inhibitors of in vitro proteolysis are lackling in the anticoagulant mixture in which the blood is collected. At the moment, It is unclear what the cause of the enhanced fibrino(geno)Iytic activity in normal newborns at birth is.

Flbrincogenlalytic activity is the result of the relative activitles of tissue-plasminogen activator (TPA) and a fast-acting tPA Inhlbitor. Thus, increased fibrinlogenlolytic activity may be the result of increased secretion of TPA from endothellal cells and/or a decreasend level of +PA inhibitor. The latter may be caused by increased levels of activated proteln C (APC), which is known to decrease the activity of HPA Inhlbitor (24).

The enhanced flbrin(ogen)olytic activity is probably one of the protectlve mechanisms agalnst the development of thrombosis in the umblillcall card vessels.

\section{References}

1. Montgomory, R.R., Marlar, R.A., Glll, J.C. Newborn haemostasls In: Clinics in Haematology, $14(2), 443$, Saunders Corp. London, Phlladelphia, Toronto (1985)

2. Lane, P.A*, Hathaway, W.E. Vitamin K in Infancy. J. of Pedlatrics, $106(3) 351$ (1985)

3. Altman, R., Henker, H.C. Contact activation in the extrinslc blood clotting system. Thromb. Dlath. Haem. 18, 523 (1967)

4. Herker, H.C., Muller, A.D., congrlJP, R. The estimation of activated human blood coagulation factor VII. J. of Mol. Med. 1, 127 (1976)

5. Bertina, R.M., Veltkamp, J.J. The abnormal factor IX of haemophllla B+ varllants. Thromb. and Hamost. 40, 335 (1978)

6. Bertina, R.M. More than one type of factor $X$ in plasma of patients using oral antlcoagulants. Thromb. Haenost. 47, 187 (1982)

7. Nalman, J.L. Clotting and bleeding in cyanotic congenttal heart dlsease. J. of Pedlatrics 76, 333 (1970) 
8. Hemker, H.C., Veltkamp, J.J., Hensen, A., Loelliger, E.A. Nature of prothromin synthesis. Preprothrombinemla in vitamin $K$ deflclency. Nature, 200, 589 (1963)

9. van Doorm, J.M. De zogenaamde vitamlne K deflelentle van de pasgeborene, Thesis, Groningen 1976

10. Hathaway, W.E. Fibrin spllt products in serum of newborn: posslble technlcal errors. Pedlatrles 45(1), 154 (1970)

11. SchettInl, F., Altomore, M., Montone, A. Determinazlone quantlative del prodotti dl sclssime flibrlnogenea.flbrina nel slerrro di noonatl a termine. Boll. Sco. I1t. Blol. Sper. Lll, 121 (1976)

12. Kirchoff, B.R.J., Hohelsel, M., Keefer, L.K Hemker, H.C. Hemmung der Ger Innung in Nabel schnurvenenplasma. Z. Geburtshll fe und Perinat. 183, 163 (1979)

13. Suzuk1, S. Studies on coagulation in newborn Infants: Liver maturation and vitamin $K$ procoagulant Inhilbitor relations. J. Perin. Med. 7, 229 (1979)

14. Hamulyák, K., Devllée, P.P., Nieuwenhulzen, W., Hemker, H.C. Reevaluation of some propertles of fibrinogen purlfled from cord blood of normal newborns. Thromb. Res. 32, 301 (1983)

15. Hemker, H.C., Hemker, P.W. Kinetic aspects of the Interaction of blood clotting enzymes IV kinetics of competitive inhlbition in coagulation tests. Thromb. Dlath. Haemoorh. 29, 364 (1968)

16. Henker, H.C., Swart, A.C.W., Alink, A.M.d. Artiflcial reagents for factor WII and factor $X$, a computer program for obtaining references tables for one stage determinations in the extrinsic system. Thromb. Dlath. Haemorrh. 27, 205 (1972)

17. Rylatt, D.B., Bllake, A.S., Lottis, D.A. et al. An Immunoassay for human D-dlmer using monoclonal antlbodles. Thromb. Res. 31, 767 (1983)

18. Nleuwenhulzen, W., Gravesen, M. Anticoagulant and calclum-binding propertles of high molecular weight derlvatlves of human flbrinogen. produced by plasmin (fragments $x$ ). Blochim. Blophys. Acta 708, 313 (1982)

19. Nleuwenhulzen, W., Voskullen, M*, Hermans, J. Antlcoegulant and calclumblindling propertles of high molecular wellght derlvatives of human fibrinogen (plasmin fragments $Y$ ). Blochim. Blophys. Acta 708, 313 (1982)

20. van Ruyven-Vermeer, I.A.M*, Nieuwenhulzen, W., Haverkato, F., TIman, T. A novel method for the rapid puriflicatlon of human and rat fibrincogen: degradation products in high ylelds Hoppe-Seylen's Z. Physlol. Chemle $360,633(1979)$

21. MCNInch, A.W., Orme, R.L., TrlPP, J.H. Haemorrhaglc disease of the newborn returns. Lancet 1, 1089 (1983)

22. Lane, P.A., Hathaway, W.E., Glthers, J.H. et all. Fatal Intracranlal haemorrhage in a normal infant secondary to vitanin $K$ deflelency. Pedlatrlcs $8[72,562$ (1983) 
23. Metnzer, M.C. Polycytheenla and the hyperviscosity syndrome in newborn infants. In: Clinles in Haematology 7:1, 63 (1978)

24. Wan Hinsbergh, V.M.W., Bertina, R.H., van Wijngaarden, A. et al. Activated protelin $C$ decreases plasmilnogen activator inhibitor activity In endothellal cell-condlfloned medlum. Blood 65, 44. (1985) 
$-65-$

CHAPTER 4

THE SYNTHESIS OF PROTHROMBIN IN NEWBORN CALVES IN THE FIRST TEN DAYS OF LIFE 
In thls study, we describe the synthesls of the coagulation factors II (prothrombin) and VII in the first ten days of 11 fe in newborn calves. At birth the levels (coagulation activity) ranged from 35-65\% of adult values. Within 3 days adult vallues were found, ranglng from 70-110\%. The levels of factor VII Increased more rapldly than the levels of prothrombin. In none of the samples of normal calves descarboxyprothrombln could be demonstrated. This allows us to conclude that a vitamin $k$ defliclency cannot be held responsible for the lower lavels found in newborns. An additlonal argument against the vitamin $k$ deflclency hypothesis is based on the flinding, that the administration of abundant vitamin $k_{1}$ before dellivery was not assocllated with higher values at birth or a more rapld increase after birth. The possibllity, that newborns are unable to secrete descarboxy coagulation factors into the circulation in vitamin $K$ deficlency states, was excluded by the fact that these products appeared in newborn plasma, upon the adminlstration to the mother of low doses of the vitamin $k$ antagonlst phenprocoumon for two weeks before blrth.

The fact, that the vltam $\mid \mathrm{n} K$-dependent coagulation factors at birth are around $50 \%$ of the adult values could partlally be explained by an increased fetal plasma volume before birth (foetus plus placenta), assuming that this would Imply an Increased breakdown constant, and the normallization of thls vollume and breakdown constant after blrth. In this way, the Increase of the factors after birth could partially be explained.

\section{Introduction}

Brlnkhous (1) was the first to demonstrate that the prothromb in levels in normal newborns are lower than in adults. Since then it has been well establlshed that at birth all the vitanln K-dependent coagulatilon factors 11, VII, $I X$ and $X$ and the antlicoagulation factors Protein $C$ and $S$ are decreased to 30-60\% of the normal adult levels (2). In 1894 Townsend (3) introduced the term "haemorrhaglc disease of the newborn", a generallized bleeding syndrome in otherwlse healthy infants, that occurred in the first weok of $11 \mathrm{fe}$. This syndrome as attributed to a vitamin $k$ defliclency soon after the discovery of this fat soluble vitamin in 1935 by Dam (4).

The administration of vitamin $K$ was clalmed to prevent this bleeding disorder $(5,6,7,8)$. Thls could not be conflrmed by other authors, who found no dlfferences with regard to the incldence of bleeding problems between newborns who did and those who did not recelve vitamin $K$ prophylaxls at birth. However, in most studles higher prothrombln levels in plasma were reported in the group newborns that recelved vitamin $k$ prophylaxis $(9,10,11,12)$. It became clear that other factors could also be responsible for bleeding problems, such as consumption of fibrlinogen, factor $V$ and platelets and increased fibrinolysis. It is a well known observation that 
disseminated Intravascullar coagulation and platelet consumptlan is comnon disorder in the neonatal perliod (13).

If a vitamin $K$ deficlency in normal newborns is present at blrth it would be expected that descarboxy-coagulation factors can be demonstrated in umbllical cord plasma. This point is controversial In the llterature. Some authors find no evidence for the presence of descarboxy-coagulation factors $(14,15)$ whereas others demonstrate an altered prothirombin peak on crossed imunoelectrophoresis $(16,17)$. The careful study of van Doorm ot al. demonstrates beyond reasonable doubt that no descarboxy-prothrombln can bo demonstrated in umbllical cord plasma in a normal Dutch (probably Westorn European) population of newborns (15). The absence of descarboxy-coagum lation factors can theoretically also be due to the fact that newborns are unable to secrete these factors from the Ilver cell Into the circulation. In man, only a few studles have been done $(18,19)$ to evaluate the coagulation and fibrinolytic system in the first week of Ilfe of normal full-term Infants. Many problems are encountered such as relatively largo amounts of blood required and the difflculty in obtaining adequate materla! by a perfect venapuncture. In one of these studles (19), it was tried to solve these problems by using new micromethods and chronogenlc substratas. None of these studles solves the problem of a possible vitamin $k$ deflelency of the newborn. As it is ethlcally Impossible to permit child birth in a woman that is known to be vitamin $K$ deficlent and as the Dutch health care system makes such an event infinitely improbable as a chance occurrence, we have therefore chosen an animal model. We studied the synthesis of prothrombin in the first tan days of Ilife in normal newborn calves, measuring the prothrombin levels by clatting and Immunological methods.

We also administered vitamin $K_{1}$ and the vitamin $K$ antagonist phenpracoumon to the mother, to see whether the synthesis of prothrombin could be accelerated in the presence of abundant amounts of vitamin $K$ and to sere if the newborn calf is able to secrete descarboxy-coagulation factors Into the clrculation.

\section{Materlal and methods}

Blood samples were obtalned from 30 normal healthy adult cows to serve as a normal pool for the bovine specles. The blood was collected in 1 vol $0.1 \mathrm{M}$ trisodium citrate alhydrate per 9 vol blood. plasma was prepared by centrifugation at $2000 \mathrm{~g}$ for $15 \mathrm{mlnutes}$ and rendered platelet free by a second run at $20.000 \mathrm{~g}$ for $30 \mathrm{minutes.} \mathrm{Allquats}$ of $1 \mathrm{ml}$ platelet free

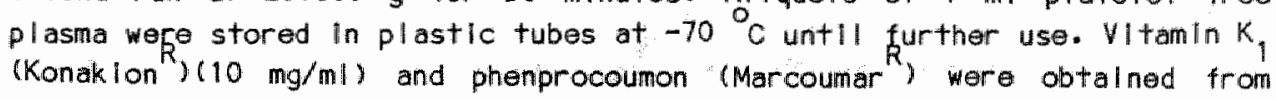
Hoffmann La Roche, Basle, Switzerland. Prothromblin levels were measured in 6 calves during the first 10 days of 11 fe after a normal pregnancy and birth a terme. To two pregnant cows vitamin $K_{1}$ was given for 2 weeks before del Ivery in a dosage of twlce a day $5 \mathrm{mg}$ Intravenously. 


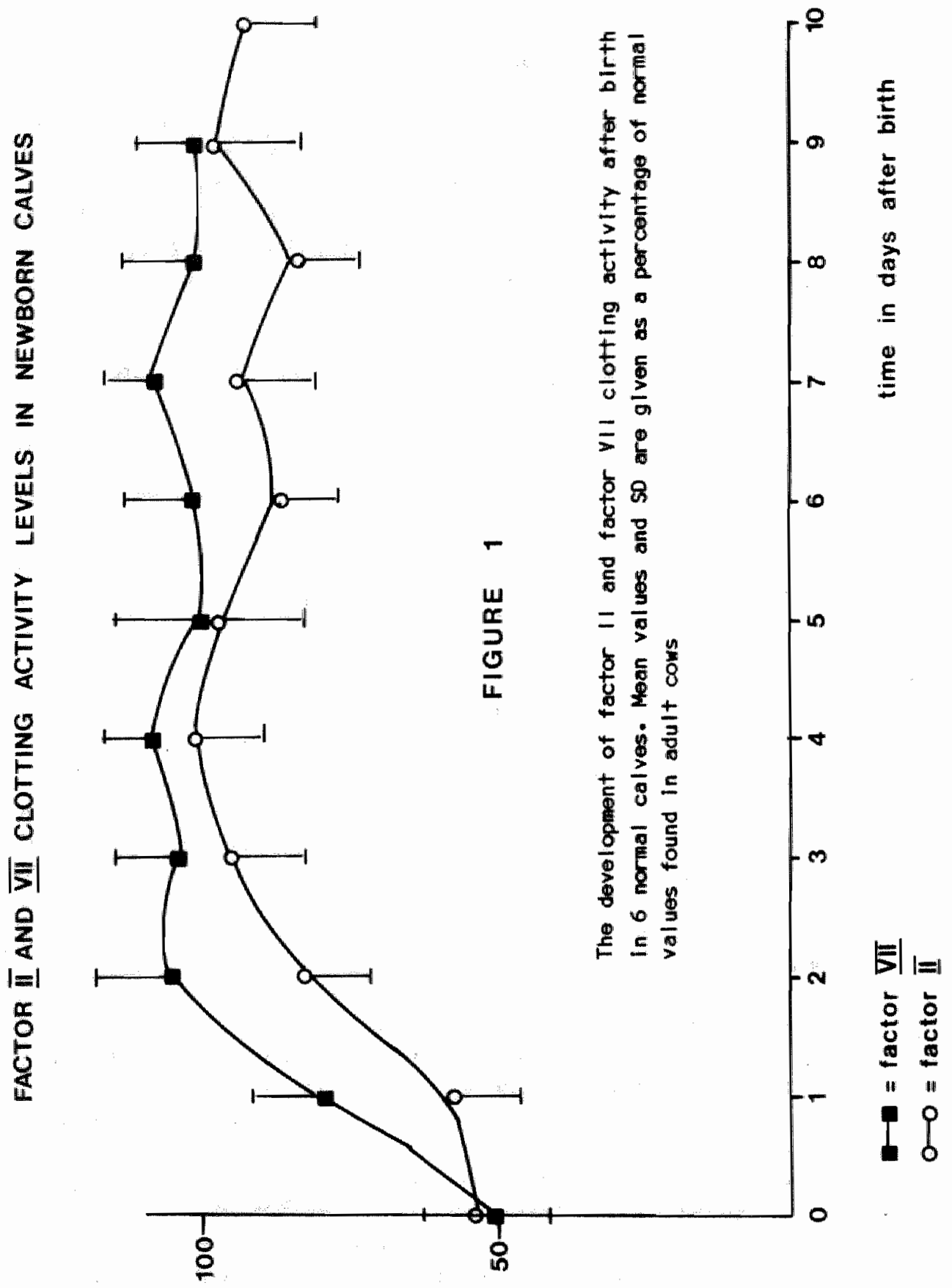

senjen Hnpe to $\%$ u! Kl!n!loe Gu!nolo 


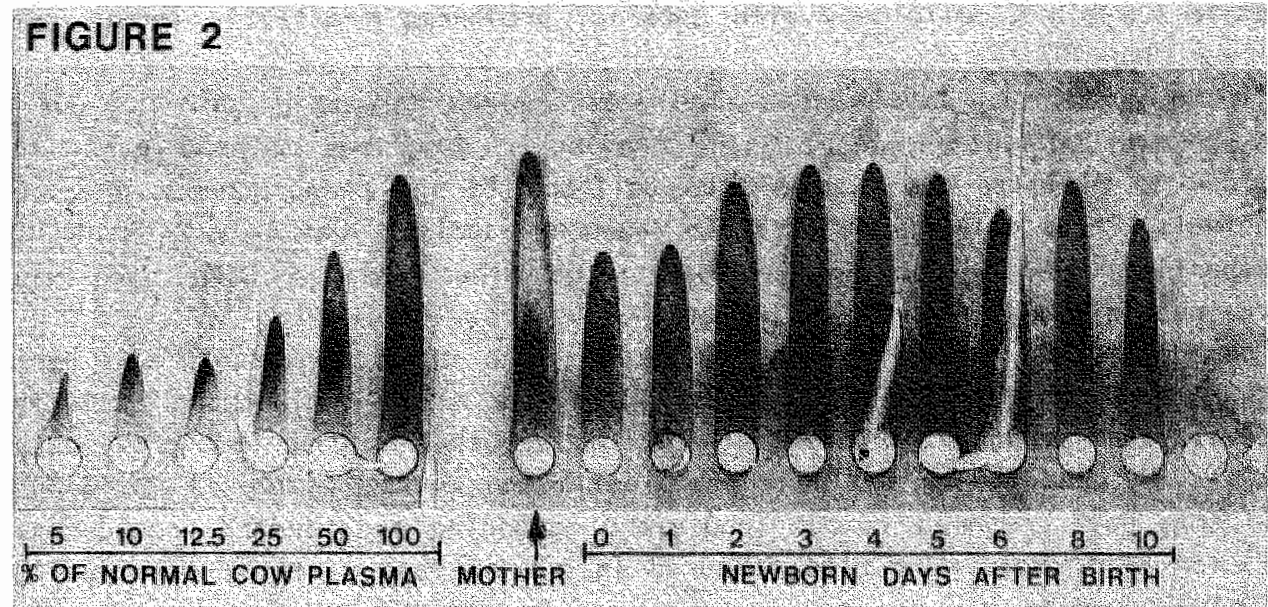

The development of prothrombin antigen levels of one of the six normal calves after birth. (rocketimunoelectrophoresis according to Laurell with a canlne antl-bovine prothrombln ant (body).

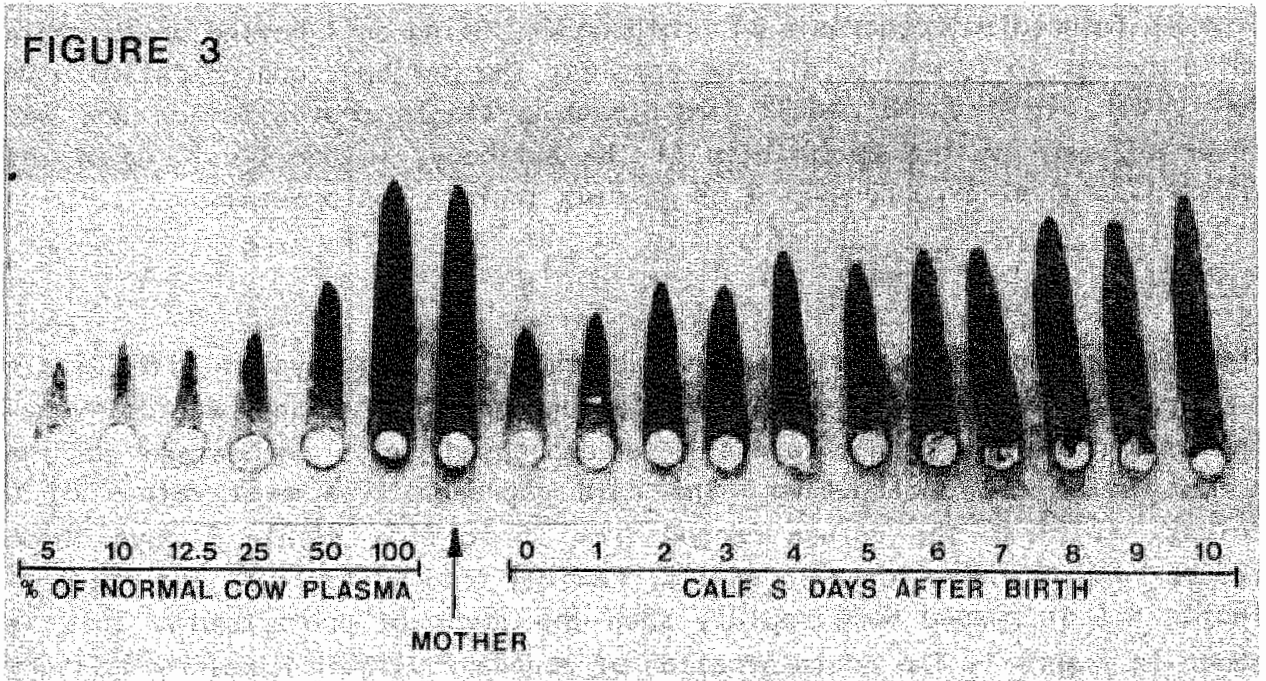

The development of the prothrombin antigen levels after birth in calf $S$. 
Two other pregnant cows were glven low dases of phenprocoumon Intravenously (mean dose dally $5 \mathrm{mg}$ ) for 2 weeks before dellvery to provlde a steady state vitamin $K$ deflclency with maternal prothrombin activity levels not lower than $70 \%$.

Plasma vltamin $K_{1}$ levels were kindly determined for us by Dr. Thljssen, department of pharmacology, using prevlously described methods (17). In order to minimize the risk of the dellivery in the phenprocoumon treated animals, these calves were born vla Caesarean section CDr. A. v.d. Bogaard, department of medlcal mleroblology). The other animals were born via vaglnal dellvery. All delliverles were uneventful.

The blood from the calves was collected by a clean venapuncture of the Jugular veln after discarding the first few ml's. Prothrombin activity levels mere mesured in an one stage clotting assay as described prevlously (18). We used bovine brain thromboplastin and bovlne factor 11 deflalent plesma, both prepared in our laboratory accordling to standard procedures. Factor VIl levels were also measured in a one stage clotting assay using bov ine reagents.

The percentage of prothrombin and factor $V \| l$ clotting activitles was calculated on the basis of dillutions of normal adult cow plasma in a computer program developed by our department (21). All measurements were performed In duplo. Prothrombin antigen levels were measured by rocket immunoellectrophoresis according to Laurell (22) using a canine anti-bovine prothrombin antl body.

Crossed Immuncelectrophores/s of prothrombin, using anti-bovine prothrombin antlbody was performed in all the samples. The antlbody concentration used was 1 vol \%. In normal adult cow plasma a single precipltation arc was observed, proving the speclificity of the antibody. In the first run of the crossed Immuncelectrophoresils 2 mM calclum lactate was present.

Results

The prothranbin levels were measured in the first ten days of llfe in six normal, full term calves, born after an uneventful pregnancy and dellvery. The prothrombin actiwity levels were expressed as a percentage of the normal adult cow pool values. The data represent the mean values of 6 calves. At blrth the vallues ranged from 35 to $65 \%$. Within 3 days these values rose to those found in adults, ranging from 70 to $110 \%$. The level of factor VII Increased more rapldiy than the level of prothrombin. This is shown in figure 1. The administration of abundant vitam lin $k$ before dellvery was not assoclated with higher values at blrth or a more rapid increase. The values found in these calves were in the same range as the values found in the normal calves. In the cows we found $21-25.8 \mathrm{ng}$ vitamin $K_{1} / \mathrm{m}$ l plasma and In their offspring 4-6 ng vitamin $K_{1} / \mathrm{ml}$ plasma.

Flgure 2 shows the factor 11 levels as determined by rocket immunoelectrophoresis in one of the six normal calves in the first ten days of 11 fe. We 


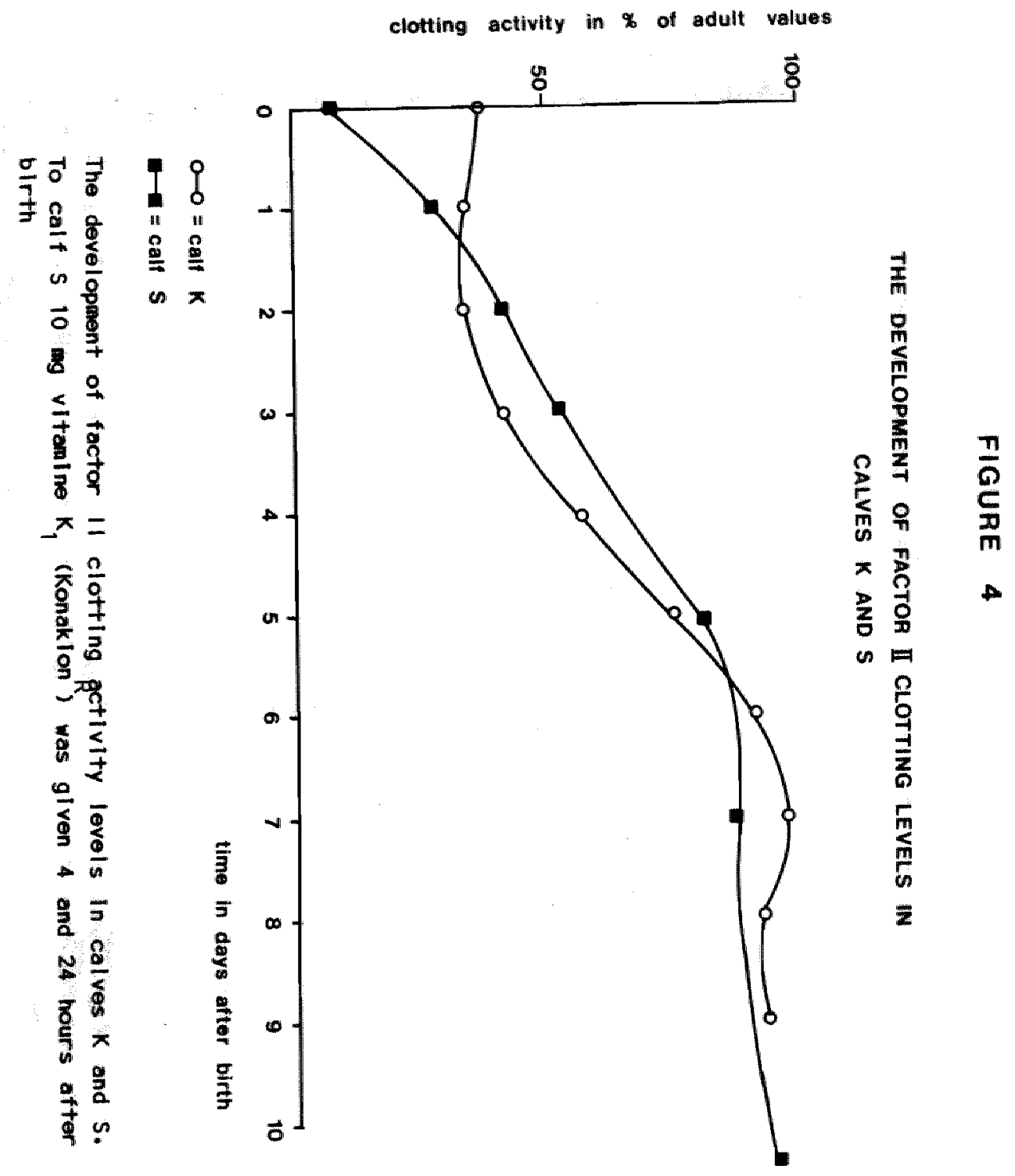




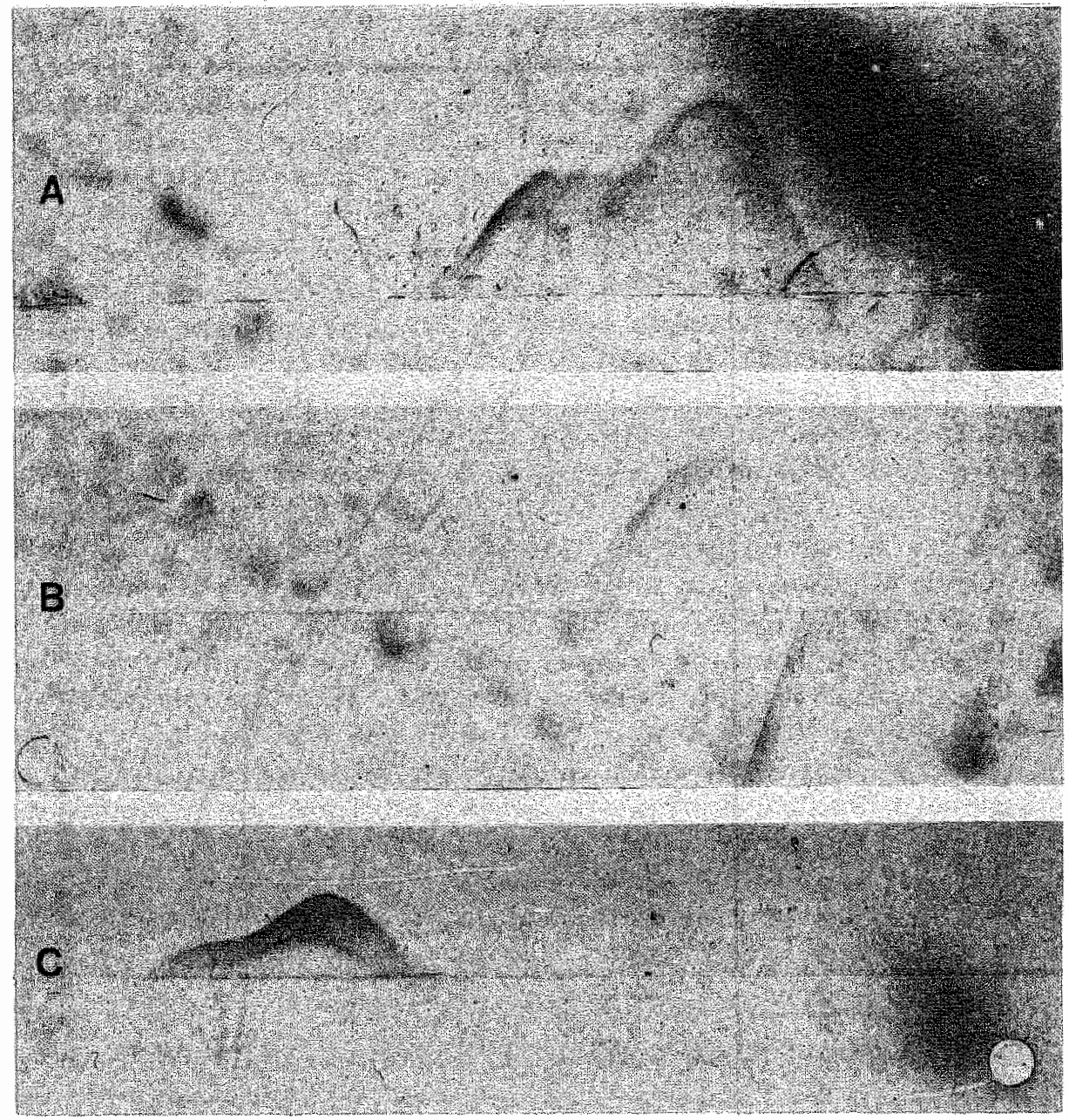

\section{FIGURE 5}

Crossed Immunoelectrophoresils patterns against bovine anti-prothrombin antibody

A: $1: 1$ mlxture of normal adult cow plasma and plasma of calf $s$ obtained at birth

B: plasma of calf $S$ obtalned at birth

C: $p$ lasma of calf $K$ obtalned at birth 
found no discrepancles between the prothrombln levels measured by the one stage method (clotting activity) and the levels determined inmunologlcally by rocket Immuncelectrophoresis. Crossed Immunoelectrophoresis (CIE) of adult cow and newborn calf plasma showed a single precipltation arc at the same position (results not shown). We therefore concluded that no descarboxyprothromb in occurred in these plasmas.

Two pregnant cows were glven low doses phenprocoumon durling two weeks before dellivery. The dosage was adjusted in order to keep the maternal prothrombin concentration between 70 and $80 \%$ of normal. In one of the pregnant cows $(K)$ the phenprocoumon was stopped 48 hours before dellivery. At birth the factor 11 concentration in calt $K$ was $36 \%$ (clotting assay) and the ratio antlgenlc-blologlcal level 1.4. In calf $S$ the prothrombin concentration (clotting assay) was nuch lower: $8 \%$ and the ratlo antlgenic-blological level was 4.3 .

In figure 3 the results are shown of the factor 11 antigen levels, detarmined by rocket immunoelectrophoresis of one of these two calves (calf $s$ ). In figure 4 the development of the prothrombin clottling activity cone stage method) Is shown of these twp calves in the first 10 days of IIfe. To calf S $10 \mathrm{mg} v i t a m i n K_{1}$ (Konakion) was adminlstered 4 and 24 hours after blith, to calf $K$ no vitamin $K$ was given. In these calves a considerable dellay was found in the synthesis of prothrombin, when compared with normal newborn calves.

In figure 5 crossed immunoelectrophoresls patterns are shown of plasma of calves $K$ and $S$ obtalned immediately after birth. In calf $K$ a double peak was observed (figure 5c). In plasma of calf $S$, at blrth, almost all prothrombin related antigen migrated to the positlon of descarboxyprothrombin in the presence of calclum lactate $(2 \mathrm{mM})$ in the first run (flgure 5B). A mixture of normal adult cow plasma $1: 1$ with plasma of calf $S$, obtalned at birth, showed a double peak (flgure 5A).

\section{Dlscussion}

At birth, the levels of the vitamin K-dependent coagulation factors are around $50 \%$ of the normall values found in adults. The fact that the concentration of these proteins in plasma is lower in newborns has been accepted generally. Most studlos have. been performed in humans, but the same is also observed in a number of animals such as sheep, dog, rabbilt and pilg (23). This article as far as we know for the first time denonstrates the phenomenon in the cow.

The reason why the vitain $k$-dependent coagulation factors are low at birth is unknown. It has been postulated that this is due to an "lmmaturlty of the synthetic mechanism of the vitamin $k$-dependent coagulation factors in the newborn liver", with or without a vitamin K defliclency. Theoretically, the plasma level of a protein is determined by the equillibrlum between lts synthesis and its breakdown. The synthesls of the vitamin K-dependent 
coagulation factors occurs in the Ilver. As is often the case in plasma protelns, the endproduct of the rlbosomal proteln synthesis in the hepatocyte, is not the final product. Vitamin $K$ is required for the carboxylation of a speciflc sequence of Glu-resldues at the $\mathrm{NH}_{2}$-terminal end of the vitamin $K$-dependent coagulation factors to form Gla-residues.

In the case of a vitamin $K$ deficlency uncarboxylated precursor molecules are secreted into the clrculation, when the protein synthes is capacity of the II ver exceeds the carboxylase system. In our study we found no evidence for a vitaln $K$ deficiency in normal newborn calves, as we were unable to demonstrate the presence of descarboxy prothrombln in plasma: in all samples the prothrombin antlgen levels parallelled the prothrombin clatting activity levels. In crossed Immunoelectrophoresis patterns agalnst bovine antiprothrombin a single precipitation are at the normal position was found. This allows us to conclude that a vitamlin $K$ deficlency cannot be hell responslble for the lower levels found in newborns.

Accordiling to Shearer, normal plasma vitamin $K_{1}$ levels in humans are in the range of $0.1-2 \mathrm{ng} / \mathrm{ml}$ plasma (24). We could conflirm the results of shearer (24) who found much lower vitamin $k$, levels in umblilical cord plasma in humans upon the adminlstration of vltamin $K_{1}$ to the mothers before dellvery. In our study in the bovine system, we adminlstered abundant vitamin $K_{1}$ to the mother before dellvery, whlch resulted in vitamin $K_{1}$ levels of $4-6 \mathrm{ng} / \mathrm{ml}$ in the plasma of thelr offspring, whereas in the corresponding maternal plasmas much higher values were found $(21-25.8$ $\mathrm{ng} / \mathrm{m} /$ ). These values are much higher than the normal plasma values and must therefore be regarded as more than sufficlent for an optimal vitamin K-dependent carboxylation reaction. In these calves, the development of the prothrombin levels after birth, was in the same range as in the other calves. These results are an additlonal argument against the hypothesis thet a vitamin $K$ deflclency is responslble for the lower prothrombin levels In newborns.

The protein synthesls capaclty of the newborn calf Ilver seems to be remarkably "mature". Adult values were reached wilthin 4 days after birth, both for factor VII and prothrombin clotting activity levels. The factor VII levels Increased more rapldiy, presumably because of its shorter half llfe time. The Increase of the vitamin K-dependent coagulation factors after blrth could be due to the major changes in hepatlc blaod flow that accur after blrth. As an alternative explamation, we can explain our results by the Increased volume of the fetal plasma compartment ifetus plus placenta), assuming that this would Imply an increased breakdown constant, and the normallzation of this volume and breakdown constant after birth. In thls way, the increase of the factors after birth could partially be explained. It may be questloned, It our results could be extrapolated to the human situation. The few results avallable at the moment indicate that also In man the factor VII levels reach adult values within one week, the prothrombin and factor $X$ levels have been described to increase slowly and 
to reach adult values in around 3 months, Independent of the adminlstration of vitamin $k$.

As mentloned above, the results of these studies can be critlolzed. Many problems are encountered, such as difflicultles in obtaining adequate materllal and methodological problems.

\section{References}

1. Brinkhous, K.M., Smith, H.P. "Warner, E.D. Plasme prothrombin levels in normal infancy and in haemorithaglc dlsease of the newborn. Am. J. Med. Scil. 193, 475 (1937)

2. Montgomery, R.R., Marlar, R.A., Glll, J.C. Newborn haemostasls in: Clinies in Haematology 14 (2), 443. W.B. Saunders Company London Phil ladelphila Toronto, (1985)

3. Townsend, C.W. The haomorrhagic disease of the newborn, Arch. Pedlatr. 11,559 (1984)

4. Dam, H. The antlhaemorrhaglic vitamin of the chlck, Nature, 135, 652 (1935)

5. Nyegaard, K.K. Prophylactic and curative effect of vitamin $K$ in haemorrhaglc disease of the newborn. Acta Obstet Gynecol. Scand. 19, 361 (1939)

6. Aball1, A.d., De Lamerens, S. Coagulation changes in the neonatall perlad and early infancy. Pediatr. Clin. North Am. 9, 785 (1962)

7. Sutherland, J.M., Glueck, H.l., Gleser, G. Haemorrhaglc disease of the newborn. Am. J. Dis. Chlld. 113, 524 (1967)

8. Vlettl, T.J., Murphy, T.P., James, J.A., Pritchard, J.A. Observatlons on the prophylactic use of vitam in $K$ in the newborn infant. J. Pedlatr. 56,343 (1960)

9. Denton, R.L. Vitamin $K$ for the newborn? Pediat. Clin. N. Am. 8, 455 (1961)

10. McElfresh, A.E. Coagulation during the neonatal perliod. Am. J. Med. $\mathrm{Scl} \cdot 242,771(1961)$

11. Parks, J., Sweet, L.K. Does the antenatal use of vitamin $K$ prevent hemorrhage in the newborn infant? Amer. 1. Obstet Gynec. 44, 432 (1942)

12. Sanford, H.N., Shmigelsky, J., Chapln, J.M. Is adminlstratlion of vitamin $k$ to the newborn of cllinical value? J. Amer. Mad. Ass. 118, 697 (1942)

13. Hathaway, M.E., Mull, M.M., Pecket, G.S. Disseminated Intravascular coagulation in the newborn. Pedlatrles 43, 233 (1969)

14. Malla, R.G., Preston, F.E., Mitchell, V.E. Evidence agalinst vitamin K deflclency in normal neonates. Thromb. Haemostas. 44, 159 (1980)

15. v. Doorm, J.M., Muller, A.D., Hemker, H.C. Heparln-llke Inhlbitor, not $v i t a m i n k$ deflclency in normal neonates. Lancet 1852 (1977)

16. Muntean, W., Peker, W., Rosanelll, K., Mutz, 1.0. Immunologlcal studles of prothrombin in newborns. Pedlatrlic. Res. 13, 1262 (1971) 
17. Corrligan, J.J., Krlje, J.J. Factor II levels in cord blood. Correlation of coagulant activity with immonoreactlive proteln. J. Pedlatr. 97, 979 (1980)

18. Hurlet-Blrk Jensen, A., Jasso, F*, Zamet, P., Monset-Couchard, M*, Minowskl, A. Evolution of blood clotting factor levels in premature Infants during the first ten days of IIfe. Pedlatr. Res. 7, 638 (1973)

19. Peters, M., ten Cate, J.W., Jansen, E., Breederveld, C. Coagulatlon and fibrinolytlc factors in the first week of llfo in healthy infants. J. of Pedlatrics. In press (1985)

20. Wlison, A.C., Part, B.K.. Quantltative analysls of pharmacologlcal level of vitamin $K_{1}$ in rabbit plasma by high performance lliquid chromatography. J. Chromatogr. 277, 292 (1983)

21. Henker, H.C., Swart, A.C.W., Allnk, A.M.J. Artifliclal reagents for factor VII and factor $X$, a computer program for obtaining reference tables for one stage determinations in the extrinsic system. Thromb. Diathes. Haemorr. 27, 205 (1972)

22. Laurell, C.B. Quantitative estimation of proteins by electrophoresis in agarose gel contalning antlbodles. Analytlcal Bloch. 15, 45 (1966)

23. Masslcotte, P., Mitchell, L., Andrew, M. Animal modells of neonatal coagul lation. Thromb. Haemost. 54 (1) 258 (1985)

24. Shearer, N.J., Rahm, S., Barkhan, P., Stlimmler, L. Plasma vitamin $K_{1}$ in mothers and their newborn bables. Lancet II, 460 (1982) 
CHAPTER 5

THE PLACENTAL TRANSPORT OF [3H]VITAMIN K IN RATS

K. Hamulyák, M.A.G. de Boer-van den Berg', H.H.W. ThlJssen ${ }^{2}$, H.C. Hemker ${ }^{1}$ and $C$. Vermeer

Departments of Blochemistry ${ }^{1}$ and Pharmacolagy ${ }^{2}$,

University of Limburg,

P.0. Box 616,

6200 MD Maastricht,

The Netherlands. 
Sumnary

In this paper we describe the placental transport of $I^{3} \mathrm{H}$ Iwitamin $\mathrm{k}$, in pregnant rats during the first 24 h after the oral adminlistration of the viltamin. The total amount of label (expressed as dpm/mg proteln) in the fetal Ilver Increased from $1.1 \%$ (after $3 \mathrm{~h}$ ) to $10.3 \%$ (after $24 \mathrm{~h}$ ) of the values found in the corresponding maternal llvers. The maln part of the label In the fetal Hssues consisted of water-soluble degradation products

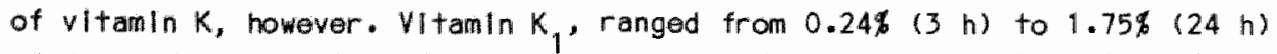
of the values found in the corresponding maternal livers. In splte of the

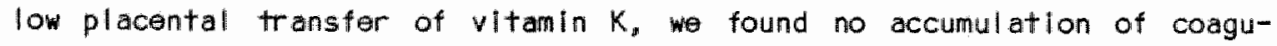
lation factor precursors in the fetal rat Ilver microsomes. Moreover, we could not demonstrate any difference between adult and fetal rat ilver mlicrosomes ith regard to the accumulation of endogenous substrate upon the administration of warfarlin. From these results we conclude that a substanHal placental barrler exlsts for the transport of pharmacologlcal amounts of vitamin $K_{1}$ but that under physlological conditions sufficlent vitamin $k$ appears to be present in the fetal I Iver to ensure a full carboxylation reaction. Whether the low placental transfer rate of vitamin $k_{1}$ can be attributed to a dose dependent mechanlism remains to be established. The carboxylase activity of adult and fetal rat liver microsomes was comparable, Indlcating that the newborn rat has an adequate carboxylating system.

\section{Introduct ion}

It has been well establlished that the concentrations of the fat-soluble vitamins in umbillcal cord plasma are lower than those in maternal plasma $(1-5)$. One of these vitamins is vitamin $k$, whlch is requilred for the synthesls of the coagulation factors $11, V \| 1, I X$ and $X$ and the anticoagulation factors Protein $C$ and $S$. Using high performance lliquid chromatography, shearer ot al. (1) demonstrated the vitanin $k_{1}$ concentratlons in umbllical cord plasma to be much lower than those in maternall plasma. Additionally, relatively small increase of vitamin $k_{1}$ was observed in the umbilical card plasma after its adminlstration to the mother, shortly before dellivery. These results are in agreement with the assumption, that the placental transport of the fat-soluble vitamins occurs only to a very limited extent.

At blrth the pliasma concentrations of the vitamin K-dependent coagulation factors in full-term nomal infants are decreased to levels of 30-60\% of normal (6). These low levels have been attrlbuted to a partlall vitamin K-defliciency, but in that case the presence of descarboxy-coagulation factors (PIVKA's) in the umbilical cord plasma would be expected, and also a substantlal difference between the coagulation factor levels in the plasma from newborns, who recelved vitamin $k$ prophylactlcally at birth and 
those who did not. Both polnts are rather controverslal in the I1terature, however. Whereas Malla (7) and van Doorm (8) could not demonstrate descarboxy-factors in umbllical cord plasma, the opposite is clalmed by Muntean (9) and Corrlgan (10). Secondly, it has not been shown convinclingly that the administration of vitamin $K_{1}$ to normal newborns accelerates the increase of the plasma levels of the vitamin K-dependent coagulation factors (8). We have studled the placental transport of ${ }^{3} \mathrm{HIvltamin} \mathrm{K}_{\text {, }}$ in pregnant rats and its distributlion over some maternal and fetal tissues at several time polnts after oral administration of the vitamin. Furthermore we have trled to flind evidence for the occurrrence of a partial vitamin K-deficlency in the fetal rat livers. The results of these experiments are presented in this paper.

\section{Exper limental procedures}

Materlals. [ $\left.{ }^{3} \mathrm{H}\right]$ vitamin $K_{1}(320 \mathrm{cl} / \mathrm{mol})$, whlch was a klnd gift, as well as non-labeled vitamin $K_{1}$ (Konakion') were provlded by Hoffmann-La Roche (Basle, Switzerland). The synthetlic pentapeptide Phe-Leu-Giu-Giu-Leu (F L E E L) was obtained from Vega Blochemical Co. (Tucson, USA) and warfar In and dithlothreltal from Sigma (Saint Louls, USA). Protosol, Bloffuor and Atomlight were from New England Nuclear (Dreleich, FRG). $\mathrm{NaH}^{4} \mathrm{CO}_{3}(56 \mathrm{Cl} / \mathrm{mol})$ was purchased from Amersham (UK). All other chemicals were obtalned from Merck (Darmstadt, FRG).

Methods. Pregnant, 12 weeks old rats (welghts 240-270 gr) of the Lewls straln were used throughout our experiments. ( ${ }^{3} \mathrm{HIWl}$ tamin $\mathrm{K},(0.04 \mathrm{mCl})$ was administered orally in $0.5 \mathrm{ml}$ sunflower oll, 24-48 h before the planned dellivery. At the Indlcated times the animals were kliled under ether anaesthesla and the perlpheral blood was collected in heparinized plastic tubes after heart puncture. The varlous organs were removed Immediatelly and washed with lcecold buffer A $10.1 \mu \mathrm{M} \mathrm{NaCl}, 0.05 \mathrm{M} \mathrm{Tr}$ is-HCl, pH 7.4). Perlpheral blood samples $(100 \mu l)$ as well as $200 \mathrm{mg}$ pleces of the maternal and fetal livers and the placentee were digested in 2 inl protosol and counted in $15 \mathrm{ml}$ Blofluor in a Packard Tricarb scintlllation counter. The results are expressed as dpm/mg protelin or dpm/mg tissue (wet welght). The results of the perlpheral blood samples are expressed as dpm/ $\mu l$. In some experlments $l^{3} H I V i t a m i n K$, was extracted from the tissues in the following way. Tissue homogenates were prepared, $1 / 1$ in buffer A in a tissue potter. To one $\mathrm{ml}$ of homogenate or perlpheral blood $3 \mathrm{ml}$ Isopropanol contalning 1 $\mu \mathrm{g}$ non-labeled vitamin $k_{1}$ were added. The mixture was shaken brlefly on a whir Imixer and extracted two times with $2 \mathrm{ml}$ hexane. The hexane fractlons were collected and counted in Atomlight. The composition of the hexane extractable radloactivity was analysed by reversed phase thin layer chromatography as follows: The combined hexane fractions were evaporated to dryness in the dark under a gentle stream of oxygen free nitrogen at $40{ }^{\circ} \mathrm{C}$. 


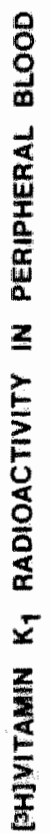

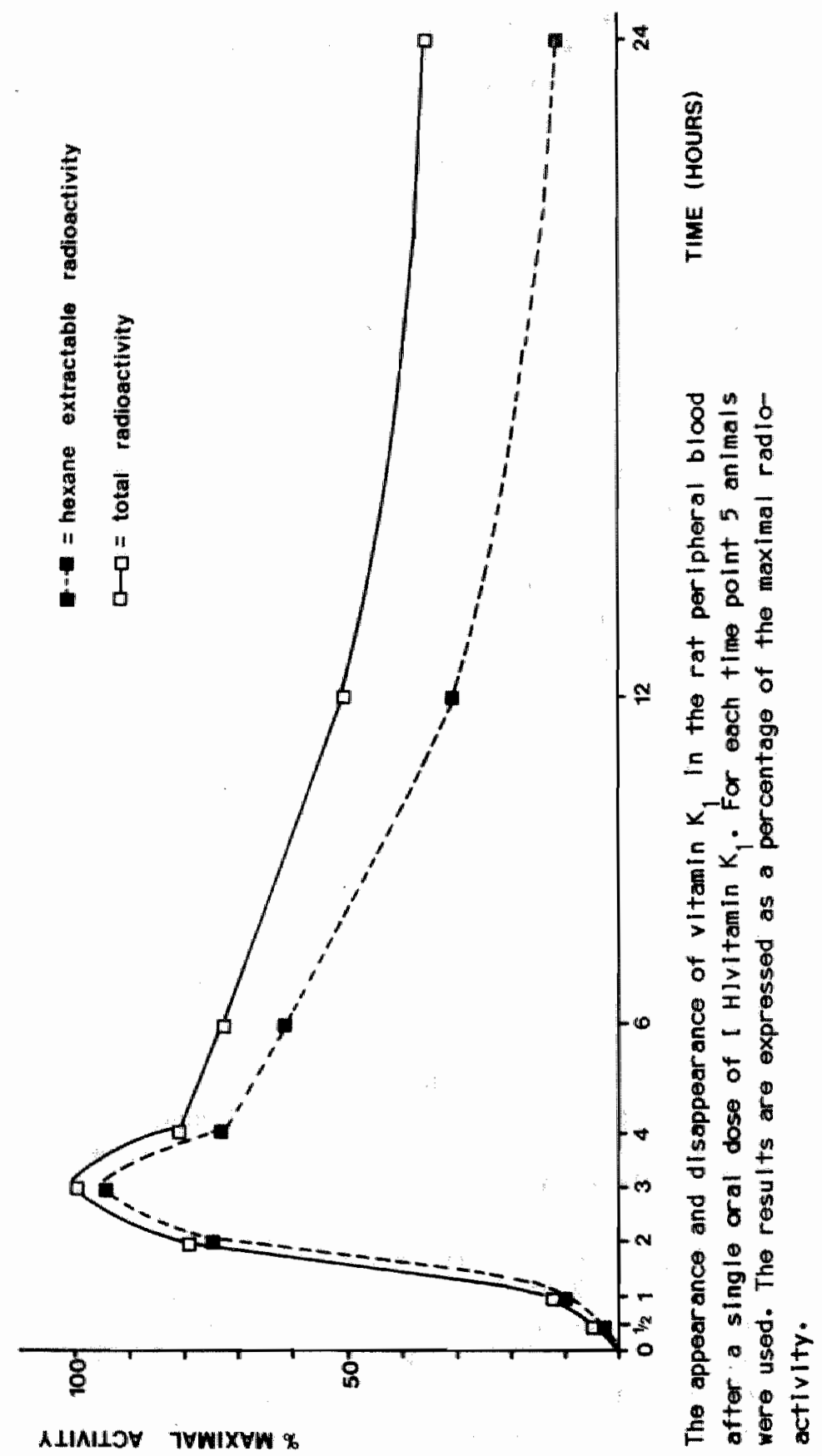


The residue was soluted in $50 \mu$ of acetonitrlle and $10 \mu 1$ thereof was applied as a stripe $115 \mathrm{~mm}$ onto the concentration zone of a Merck hlgh performance RP18 thin laver plate (Merck, Darmstadt, FRG). The plate was brlefly developed in acetonitrlle untill the solvent front reached the chromatographlic layer. After evaporation of the acetonitrlle the pllate was developed in dichloromethane/acetonltrlle contalning $1 \%$ of water $13 / 7$, v/v). Vitamin $K_{1}$ was visuallzed by Illuminating the chromatogram at 366 nm for $5 \mathrm{~m} / \mathrm{n}$. A bright blue fluorescence emerges from vitamin $k$ (Rf = 0.12 ; Rf of viltamin $K_{1}$ epoxide $=0.20$ ). The spot was scraped off and the radloactivity was counted by llquid scintlllation. By this procedure it was found that the hexane extractable radloactivity consisted malnly (\$90\%) of vitamin $\mathrm{K}_{1}$.

Microsomes from adult and fetal Ilvers were prepared as described prevlously (12). The vitamin $k$-dependent carboxylation reaction was recorded by incubating the microsomes ( $1 \mathrm{mg}$ of proteln) in $0.25 \mathrm{ml}$ reaction mixtures contalning $0.1 \mathrm{M} \mathrm{NaCl}, 0.05 \mathrm{M} \mathrm{Tris-HCl}, \mathrm{pH} 7.4,8 \mathrm{mM}$ dithlothreltol, I M $\left(\mathrm{NH}_{4}\right)_{2} \mathrm{SO}_{4}, 0.2 \mathrm{mM}$ vitamin $\mathrm{K}$ hydroquinone, $10 \mu \mathrm{Cl} \mathrm{NaH}^{14} \mathrm{CO}_{3}, 12 \mathrm{k}(\mathrm{v} / \mathrm{v})$ ethyleenglycol, $0.2 \%(w / v)$ CHAPS $(3-13$-cholamidopropylidimethyl ammonio $]-$ 1-propane sulfonate) and $4 \mathrm{mM} \mathrm{F} \mathrm{L} \mathrm{E} \mathrm{E} \mathrm{L} \mathrm{as} \mathrm{indlcated.} \mathrm{The} \mathrm{mixtures} \mathrm{were}$ Incubated in sealed tubes at $25{ }^{\circ} \mathrm{C}$. The reaction was stopped with $2 \mathrm{mi} 10 \%$ ( $w / w)$ trlchloroacetlc acld at the indicated times and non-bound ${ }^{4} \mathrm{CO}_{2}$ was renoved by bolling for 2 minutes beforp the samples were counted in Atomlight. The amount of incorporation of ${ }^{44} \mathrm{CO}_{2}$ into endogenous substrate was measured in a similar way, except that the amount of microsomal proteln was $2.5 \mathrm{mg}$ and that no $\mathrm{F} L E E L$ and $\left(\mathrm{NH}_{4}\right)_{2} \mathrm{SO}_{4}$ were present in the reaction mixture. Proteln concentrations were measured according to Lowry (11).

\section{Results}

The appearance and dlsappearance of vitamin $K_{,}$in the rat perlpheral blood was followed after single oral dose of ${ }^{3} H I v i t a m i n$, to 40 pregnant rats. For each time polnt groups of 5 anlmals were used for obtalning blood and varlous organs. As is shown in flgure 1 , the maximal vitamin $k$ concentration in blood is reached at $3 \mathrm{~h}$ and up +111 that monent degradatlon of vitemin $K_{1}$ is hardly observed. At later stages, the total label and the hexane extractable iraction thereof rapldiy diverge, thus showing the degradation of the vitamin. The results are expressed as percentage of the maximal values of the total and the hexane extractable radloactivlty.

The same rats were allso used for the preparation of varlous organs: the maternal and fetal livers and the placentae. Agaln the radloactlvity recovered in the whole tissues as well as that in the hexane-extractable fractions thereof were measured (see Table 11 ). 
As compared to the maternal llver, only very low amounts of label accumulated in the fetal llvers. Moreover it is abvious, that the main part of the label recovered from the fetal llivers or Iginates from water-soluble vitamin $K$-degradation praducts rather than from vitamin $K$ itsell. The total radioactivity found in the placentae appeared to be lower than the anount found in the perlpheral blood samples of the mother at all time points $(20-40 \%)$. From these results we concluded that (1) a consilderable placental

TABLE

The placental transfer of [ $H]-v i+\tan \mid n K_{\text {, }}$

Label (dpm/mg proteln)

TIme(h) elapsed after start of experlment 3

12 24

Maternal

Hexane extraction (\$)

Fetal IIver

Hexane extraction (\$)

Ratllo fetal/maternal

In IIver tissue:

In hexane extracts:

$\begin{array}{ccc}14287 \pm 4445 & 28471 \pm 3609 & 18536 \pm 11033 \\ 96.2 \pm 0.7 & 91.8 \pm 1.3 & 98.7 \pm 1.3 \\ 16.3 \pm 34 & 1932 \pm 214 & 2136 \pm 764 \\ 22+1 \pm 2 & 16.5 \pm 0.9 & 16+8 \pm 1.9\end{array}$

0.011

0.063

0.103

0.0024

0.010

0.017

Label In placentae tissue

(dpm/ing wet welght)

$131 \pm 58$

$149 \pm 55$

$135 \pm 50$

The dlistribution of $\left[{ }^{3} H\right]-V i t a m i n K_{1}$ in maternal and fetal tissues. The data are the means of 5 (maternal tissues) and 20 (fetal tissues) anlmals t the standard devlation at each Indlcated time polnt. The protein content of fetal Ilver was about $50 \%$ of the maternal IIver

barrler exists for the transport of vitamin $k$, and (2) that this barrler seems to be lower or absent for the water-soluble vitamin K-degradation products. SInce we were Interested whether the Impeded vitam in $K$ transport leads to a partial vitamin K-deflclency in the fetal liver, we have prepared the microsomal iractions thereof and investlgated a) the levels of endogenous substrates $6 . \mathrm{g}$. carboxylatable precursors af coagulation factors) for carboxylase and b) the amount of hepatllc carboxyllase. In the 
case of a vitamin K-deficiency an accumulation of endogenous substrate is to be expected (12). For this purpose the fetal llivers were compared wh the corresponding maternal IIvers. No differences were observed between the newborn and adult rat Ilver microsomes with regard to the accumulation of endogenous substrate (see flgure 2). We found around the same (10w) valwes in non pregnant female rats and three days ald rats (results not shown). The amount of carboxylase was determined in the presence of an excess of the synthetic substrate F L E E L and as can be seen from table 2 no signiflcant differences were observed.

TABLE 11

The vitamin $\mathrm{K}$-dependent hepatIc carboxylase actlvity

The vitamin $K$-dependent carboxylase actlvity was measured as ind lcated in METHODS, in the presence of an excess of exogenous substrate ( $F L E E L$ ). The reaction was 1 inear in the first 30 minutes. The results are given in $\mathrm{dpm} / \mathrm{mg}$ proteln/m/n.

Maternal IIver $(n=6)$

Fetal IIver $(n=5)$

$1254+178$

$955+106$

Thls indicates that the carboxylating enzyme system in the fetus is comparable with the adult carboxyllating system and therefore capable of malntalning a normal carboxylation rate. Since the amounts of endogenous substrate were low in all cases, no evidence could be obtalned for a relevant defliclency of vitamin $K$ in the fetal IIver. Although the supply of witamin $K$ in fetal. Ilver thus seems to be sufflclent for the normal functioning of carboxylase, It stlll could be that this supply is marglmal and that small perturbations have a more profound effect in the fotal than in the maternal llver. Therefore, we messured the accumulation of endogenous substrate for carboxyllase in maternal and in fetal Ilver after the subcutaneous administration of different doses of warfar in to pregnant rats, two days before the planned dellvery. The animals were klllled 24 hours after the warfarin treatment and the mlcrosiomal fractions were prepared from the maternal and fetal IIvers. The amount of endogenous substrate was determined in the absence of $F L E E L$ and expressed as $\mathrm{dpm} / \mathrm{mg}$ protein. The results are glven in figure 2 and demonstrate that the accumulation of endogenous substrate for carboxylase in maternal and fetal llver upon the administration of warfar in was comparable. 


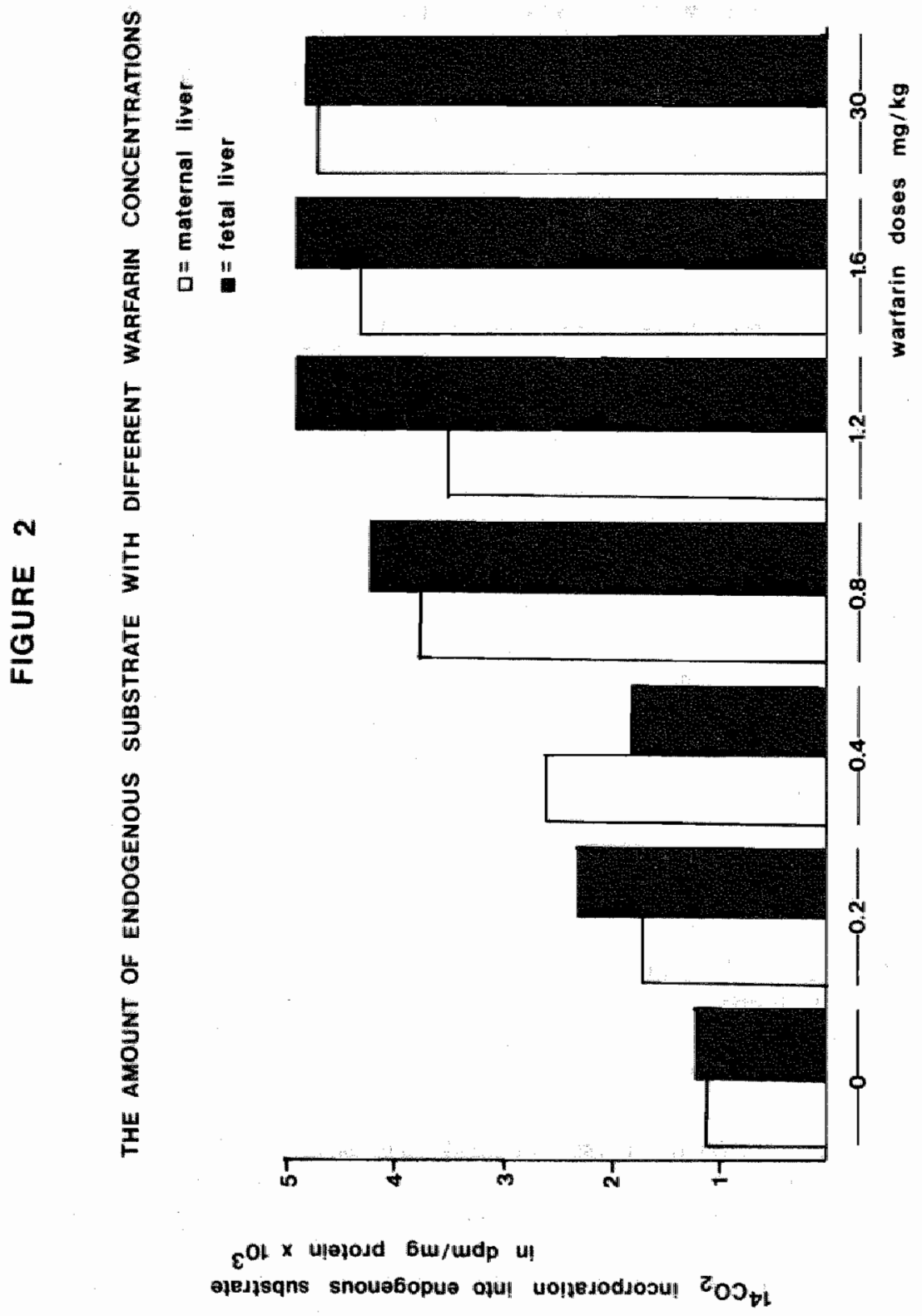


It is generally assumed, that the placental transport of the fat-soluble vitamins $A, D, E$, and $K$ resembles that of llplds. In blood plasma the vitamins are bound to protelns and lipoproteln complexes. The way in whlch the vitamins are subsequently released to the placental membranes is not yet clear, whereas the transfer from the maternal to the fetal side of the placenta is thought to occur by simple dlffusion (5). Flnally, (1lpo-) protelims again mediate in the plasme transport of the vitamins to theil fetal target organs. The complexity of this transport mechan lsm may be the cause of the $11 \mathrm{mitations,} \mathrm{which} \mathrm{are} \mathrm{set} \mathrm{to} \mathrm{the} \mathrm{passage} \mathrm{of} \mathrm{fats} \mathrm{and}$ fat-soluble vitamins through the placenta. The first indication for the existence of a placental barrier for vitamin $K$ was reported by Shearer ot al. (1), who demonstrated that the vitamin $k$ concentration in umbllicall cord plasma. Is lower than that in maternal plasma. Since these authors worked with human volunteers, the actual vitamin $K$ concentratlons in the Ilver could not be determined, however. The low amounts of vitamin $k$ in umblilical cord plasma might also be explained, for Instance, by assuming that the relatively big liver and the rapld growing bones of the fetus extract vitamin $k$ from plasma more efflciently than the corresponding maternal tissues do. The relatively low levels of the (Ilpo)proteins in newborn plasma offer another posslble explanatlon, provliling a decreased passibllity for the transport of the vitamin. Using pregnant rats as an experlmental animal system, we have demonstrated in this paper that after the oral adminlstration of vitamin $k_{1}$ to the mother, the uptake of the vitamin (expressed per ing of protein) by the fetal IIver is 1-2\% from that of the maternal liver. Obviously thls flgure is even far lower when the uptake is expressed per whole organ. Our results may also be sllghtly influenced by the vitamin $K_{1}$ present in the blood volume of the +1 ssues. For adult rat 11 ver this is supposed to be $0.26 \mathrm{\mu l} / \mathrm{mg}(13)$, for fetal IIver it is probablly somewhat higher. Correction of our data for the tissue blood volume does not lead to different concluslons, however. The fatal llvers contalned rellatively high amounts of water-soluble vitamin $k$ degradatlon products, Indlcating that the placental barrier for thase compounds is low or absent.

Since apparently the placental transport of vitamin $K$ is hampered, it is to be expected that the vitamin $K$ level in the fetal IIver is low. In the case of a vitamin $k$ deficlency the accumulation of endogenous substrate for carboxylase (coagulation factor precursors) in the hepatlc mlcrosomal fraction is to expected (12). At later stages also nom-carboxyllated coagulation factors can be detected in blood plasma. We have been unable to detect increased amounts of carboxylatable protains in the fetal llvers. Therefore, no evidence could be obtalned for a relevant witam In $k$ deflclency in fetal Ilyer, assuming that the synthests of carboxylatable protelns in fetal liver is comparable with that in adults. Moreover, in 
Wvo experiments in whlch pregnant rats were treated for a short time with different doses of warfarin, did not reveal a relatively greater increase In the accumulation of endogenous substrate in the fetal IIvers. It must be concluded therefore, that in the fetal liver probably sufficient vitamin $k$ is present for complete carboxylation reaction. Apparently this conclusion is in contradiction with the observed placental barrier for vitanin $k_{1}$, but our results may be explalned by assuming that the placental transfer of vitamin $K$ is bound to a maxilmum. Physlologlcal concentrations of the vitamin may then be transported without difflculties, but during experiments in whlch the far higher pharmacologlcal doses of [ ${ }^{3} \mathrm{HI}$ litamin $\mathrm{K}_{1}$ were administered to the animals, the placentall transport did not increase proportionally. It would thus be interesting to measure directly the levels of endogenous vitamin $k$ in normal maternal and fetall $I$ ver, but up $+11 \|$ now the determination of physlologlcal concentratlons of vitamin $k$ in tissues has proven to be a difflcult task. For technlcal reasons it was also not possible to simulate in this set of experiments the physlological situatlon obtalned vla long-term adminlstration of physlological (low) doses of vitamin K.

We conclude that, in splte of the low placental transfer rate of vitamin $K_{1}$, no vitamin $K$ deficiency can be demonstrated in newborn rats under normal conditlons. Under the assumption that the same holds for human newborns, It may be questioned, if the administration of vitamin $k$ to normal newborns at birth is indlcated. However, it will be clear, that in the case of a vitamin $K$ deficlency in the mother and/or long term treatment durlng pregnancy with vitamin K-antagonists or anticonvulsant drugs, the fetus wll be relatively more at rlsk than the mother for bleeding complications. In that case, repeated pharmacological (high) doses of vitamin $K$ are required for a normal carboxylation reaction in the fetal II ver, one dose beling not sufficlent.

\section{References}

1. Shearer, N.J., Barkhan, P., Rahlm, S., Stimmler, L.: Plasma vitamin K, In mothers and their newborn bables. Lancet 11, 460 (1982)

2. Baker, H., Frank, D., Thonson, A.D. Vitamin proflle of i74 mothers and newborns at parturltion. Am. J. Clln. Nutr. 28, 59 (1975)

3. Kuroda, E., OKano, T., MIzuno, N. Plasma lavels of $25-\mathrm{OH}$ vitamin $\mathrm{D}_{2}$ and 25-OH vitamin $D_{3}$ in maternal, cord and neonatal blood. J. Nutr. "Scl. $V$ itaminol. $27,55(1981)$

4. Martllnez, F.E., Goncalvez, A.L., Jorge, S.M., Desal, I.D. Vitamin E In placental blood and its relationship to maternall and newborn levels of vitamin E. J. of Padlatr. 99, 298 (1981)

5. Dancls, J., Schnelder, H. The Placenta: transfer and barrier function, chapter 6, p. 115. Ed. P. Gruenwald MTP publishing Co. LTD (1975)

6. Hathaway, W.E., Bonnar, J. Perlnatal coagulation. Grune and Stratton, New York (1978) 
7. Malla, R.G., Preston, F.E., Mitchell, V.E. Evidence against vitain K deficlency in normal neonates. Thromb. Haemostas. 44, 159 (1980)

8. v. Doorm, J.M., Muller, A.D., Hemker, H.C. Heparln-like inhlbltor, not vitamin $K$ deflclency in the newborn. Lancet, 1, 852 (1977)

9. Muntean, W., Peker, W., Rosanelll, K., Mutz, I.D. Immunologlcal studles of prothromb in in newborns., Pedlatrlc Res. 13, 1262 (1979)

10. Corrigan, J.J., KrlJe, J.J. Factor II levels in cord blood. Correlation of coagulant activity with immunoreactive proteln. J. Pediatr. 97, 979 (1980)

11. Lowry, O.H., Rosebrough, N.J., Farr, A.L. and Randall, R.d. J. Bliol. Chem. 193, 265 (1951).

12. C. Vermeer, B.A.M. Soute, M. de Metz and H.C. Hemker. A comparlson between vitamin $K$-dependent carboxyllase from normal and warfarlntreated cows. Blochim. Blophys. Acta 714, 361 (1982)

13. Evenwel, R.T.H. The development of spontaneous hypertension in rats. Thesis, Maastrllcht, 81 (1982) 
a 
CHAPTER 6

A NEW METHOD TO ASSESS THE AMOUNT OF VITAMIN K IN LIVER MICROSOMES

K. Hamulyäk, B.A.M. Soute and C. Vermeer

Department of Blochemistry

University of Limburg

P. O. Box 616

6200 MD Maastricht

The Nether lands 
In this paper, we describe a new method for the determination of the amount of vitamiln $k$ present in the microsomal fractions of rat- and bovine liver tlissue. This method Is based on the blologlcal activity of vitamin $k$ in its function as a coenzyme for the carboxylating enzyme system. The amount of viltamili $K$ present in the microsomal fractions is rellevant for its blologlcal activity. The values are expressed as ng phylloquinone equivalents per ming microsonal proteln.

In adult rat- and cow llver the values ranged from $1.6-4$ ng per mg microsomal proteln. Upan the administration of $10 \mathrm{mg}$ vitamin $k_{1}$ a $4-5$ fold Increase of the values was found in rats. In a prelliminary experiment we found lower val ues (around 50\%) in newborn rat IIver mlcrosomes.

\section{Introduction}

It has been well established that the natural fat-soluble vitamin $k$ compounds are Involved in a posttranslational step in the synthesls of a number of protelns (1). This process leads to the formation of gammacarboxyglutamic (GHa) residues. Besides vitamin $K$, a carboxylating enzyme system (carboxylase) is requiled for this posttranslational modiflication (1). The physlological significance of the Gla-residues is related with their binding of calclum. Gla-residues were dlscovered about ten years ago in the coagulation factor prothrombin (2). Prothrombin, as well as most other coagulation protelns, is syntheslzed in the liver. It is not generally known, that vltamin K-dependent carboxylase is also present in other tissues such as lung, kIdney, bone, spleen and testls (3). Moreover, numerous Gla-containing proteins have been detected such as bone Gia proteln (osteocalcin) and renal Gla proteln. In mast cases, however, their function is not wholly understood. Compared with the other fat-soluble vitamins $A, D$ and $E$, relatively few data are avallable on the physlological concentrations of vitamin $K$ present in blologlical samples. Thls is due to the very low concentrations of vitamin $K$ in body tissues and flulds and a number of technlcal problems.

Until 1970, vitamin $K$ concentrations were measured in the chick bloassay (4). In thls assay, chicks were fed with a diet low in vitamin $K$, which resulted in a prolongation of the prothrombin clotting time. The shortening of thls clotting time upon the addition of the sample to the diet was measured and compared wlth the effect of adding phylloquinone ( $v /$ tam In $K_{1}$ ) to the dlet. This method appeared to be rather sensitive $1200 \mathrm{ng} / \mathrm{gram}$ of dlet), but inaccurate and time consuming. Physilcochemical methods were al so unrelliable. Some Improvenent came, when chromatographical methods were introduced, such as column liquld chromatography, thin layer chromatography (ILC) and gaschromatography. The development of high performance liquid chromatography (HPLC) provided a major Improvement. Using this method, it 
became also possible to measure vitamin $K_{1}$ levels In human $p l$ asma $(5,6)$. Modiflcatlions of the HPLC method have recently been Introduced which have further Improved the efflclency and reproducablilty. In this method the

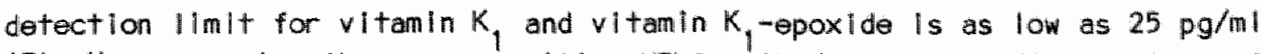
(7). However, also the very sensitlve HPLC methods have the disadvantage of not reflecting blological avallablllty of vitamin K. Therefore, we developed a new bloassay for the determination of the amount of vitamin $k$ present in liver microsomes. This method is based on the blologlcal acitivity of vitamin $K$ in its function as coenzyme for the carboxylating enzyme system, which is locallzed in the mlcrosomal fractions.

In the bloassay phylloquinone ( $v i t$ tamin $K_{p}$ ) as well as the menaquinones $\left(K_{2}\right.$ $v 1$ taminsy are measured. Both forms of witamin $k$ are known to be blologlcalIy active, although the role of the $\mathrm{K}_{2}$-vitamins in the carboxylation reaction is less well investigated than that of phylloquinone.

\section{Experimental procedures}

Materlals

Vltamin $K_{1}$ (Kanaklan ${ }^{R}$ ) was obtained from Hoffmann-La Roche (Basle, Switzerland). CHAPS (3-i (3-chollamldopropy 1-dimethyl ammon lo l-propane sulfonate) and DTT (dithlothreitol) were from Sigma (St. Louls, USA) and the synthetlc pentapeptide Phe-Leu-Glu-Glu-Leu if $L E E L$ ) was abtalned from Vega Blachemicals (Tucson, USA). $\mathrm{NaH}^{14} \mathrm{CO}_{3}(56 \mathrm{Cll} / \mathrm{moll}$ ) was purchased from Amershan (U.K.) and Atomllight from New England Nuclear (Dreleich, F.R.G.). All other chemicals were from Merck (Darmstadit, FRG).

Fenale Lewis rats of 12 weeks old (welights 220-250 gram) were used throughout our experiments. In one set of experliments pregnant 12 weeks old Lewls rats were used, as well as their offspring Immedlately after birth. All animals were fed with $\mathbb{R M N}-\mathrm{B}, 12-15$ gram dry matter per day obtalned from Hope Farms (Woerden, The Netherlands). According to the manufacturar the vitamln $K$ content of thls preparation $1 \mathrm{~s} 10.5 \mathrm{mg} / \mathrm{kg}$. Fresh cow IIvers were obtained from the slaughterhouse.

Methods

The mlcrosomal fractions of the tissues were prepared in a simillar way as descrlbed earller (3). After three washing cycles, the microsomes were suspended in buffer $A$, contalning $0.1 \mathrm{M} \mathrm{NaCl}, 0.05 \mathrm{Tr} / \mathrm{s}-\mathrm{HCl}, \mathrm{pH} 7.4,20 \%$ $(v / v)$ ethyleneglycol. The samples were stored at $-70 \%$. Proteln concentrations of the microsomal fractions were measured according to Lowry (8). The carboxylase activity was measured by incubatling $0.25 \mathrm{ml}$ reactlon mixtures at $25{ }^{\circ} \mathrm{C}$ in sealed tubes containling 0.5 - $1 \mathrm{mg}$ microggmal proteln, $0.2 \%$ (w/w) CHAPS, $4 \mathrm{~mm} F \mathrm{~F} E \mathrm{~L}, 8 \mathrm{mM} \mathrm{DTT,} 0.01 \mathrm{mCl} \mathrm{NaH} \mathrm{CO}_{3}$ and $1 \mathrm{M}$ $\left(\mathrm{NH}_{4}\right) 2_{4} \mathrm{SO}_{4}$. The reaction was stopped at 20 minutes by adding $2 \mathrm{ml} 5 \%$ trlichloraacetic acid and the mon-bound ${ }^{4} \mathrm{CO}_{2}$ was removed by bolling the solution for two minutes. The samples were supplemented with $10 \mathrm{ml}$ Atomilght and counted in a Beckman scintill ation counter. The carboxylase- 


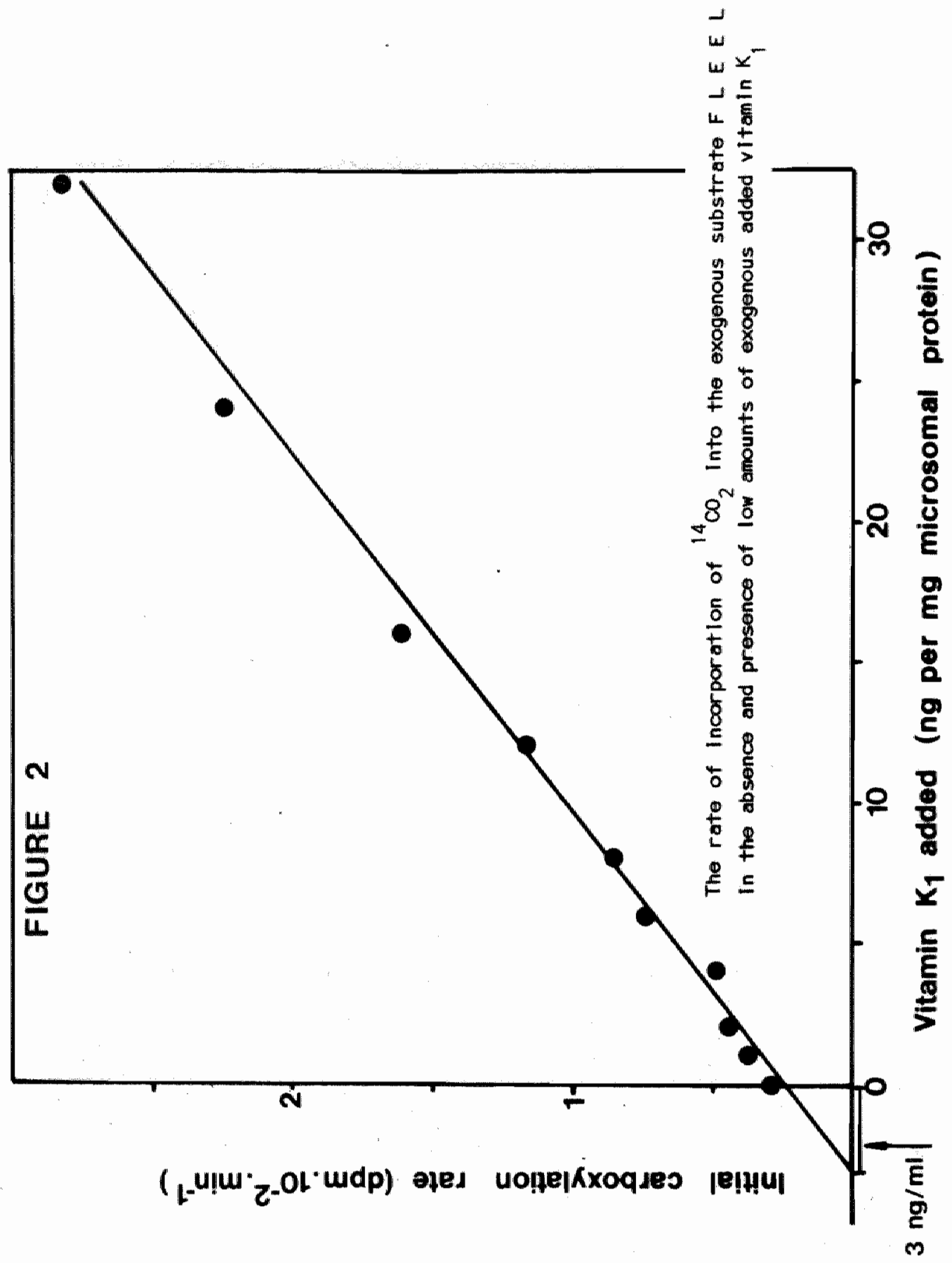


actiwity was expressed as ${ }^{14} \mathrm{CO}_{2}$ (dpim) Incorporated in F L E E L per minute. The blank values were subtracted. Simllar samples were incubated in the presence of low amounts of exagenous added $v i t$ tain in $k$, in a range from $1-16$ ng. Vitamin $K_{1}$ was diluted in buffer A Immedlately before starting the incubation to minimize the light induced degradation of vitamin K. For, each sample freshly prepared vitamin $\mathrm{k}$, dilutlons were used. The rate of ${ }^{14} \mathrm{CO}_{2}$ Incorporation was plotted agalnst the concentrations of vitamin $K_{y}$ added. This curve was llinear in the range of vitamin $k$, concentrations used. From these curves the amount of vitamin $k$ present in the sample can be calculated and expressed as ng viltamin $K$, equivalents per mi mlcrosomal proteln. To 5 adult femsie rats $10 \mathrm{mg}$ vitamin $K_{1}$ were adminlstered one hour before sacrifice. Protein concentrations were determined according to Lowry (8).

\section{Results}

In order to define optimal protein concentrations for our experiments we determined the relatlion between the protein concentration in the microsomal fractions, determined according to Lowry (8), and F L E E L carboxylation. Thlis curve appeared to be sigmoldeal, as can be seen in 1 lgure 1 . In our reaction mixtures protein concentrations were used, whlch are in the linear Rart of the sigmoldeal curve. In flgure 2 the rate of incorporation of $\mathrm{CO}_{2}$ Into the exogenous substrate $F \mathrm{~L} E \mathrm{E} L \mathrm{~L}$ is plotted against the concentration of vitamin $K_{1}$ added. Assum/ng, that the interception point on the ordinate in this curwe represents the rate of incorporation determined by the amount of vitamin $K$ present in the mlcrosomes, this amount can be calculated by extrapolating the IInear curve as indicated in figure 2 . In this case the amount of vitamin $K$ was 3 ng phylloquinone equivalient per mg mlcrosomal proteln. Using different proteln concentrations in the linear part of the slgmoideal curve, comparable results were obtalned. This is shown in figure 3 .

In adult rat liver mlcrosomes the values ranged from $1,6-4$ ng per $\mathrm{mg}$ mlcrosomal protein $(N=4)$. Comparable values were found in cow Ilver microsomes. In the vitamin $K_{1}$ treated animals 4-5 fold higher values were found. In a pllot experliment the vitamin $k$ concentration was also determined in newborn rat liver microsomes. The fligures were distinctly lawer (50\%) than those obtained in maternal rat Ilver microsomes. Further research concerning this polnt is in current progess in our laboratory.

\section{Discussion}

In the ilterature remarkable differences are reported with regard to the amount of witamin $k$ in $r$ at liver $(9,10)$. The values obtained by the chlck blaassay were much higher than those obtained by the application of high-performance liquid chromatography. Vitamin $K$ can be present in 


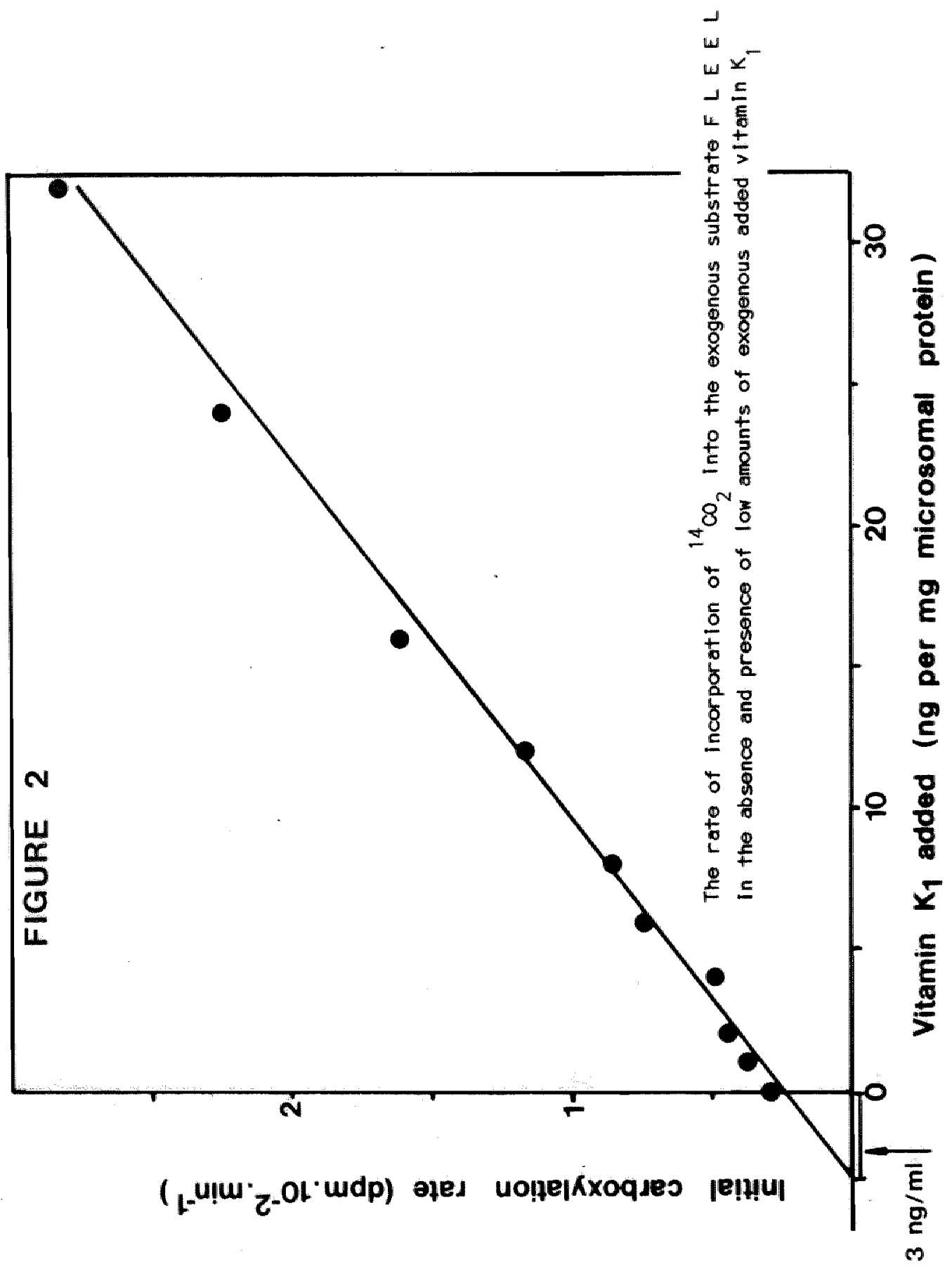


Initial carboxylation rate (dpm. $10^{-2} \cdot \mathrm{min}^{-1}$ )

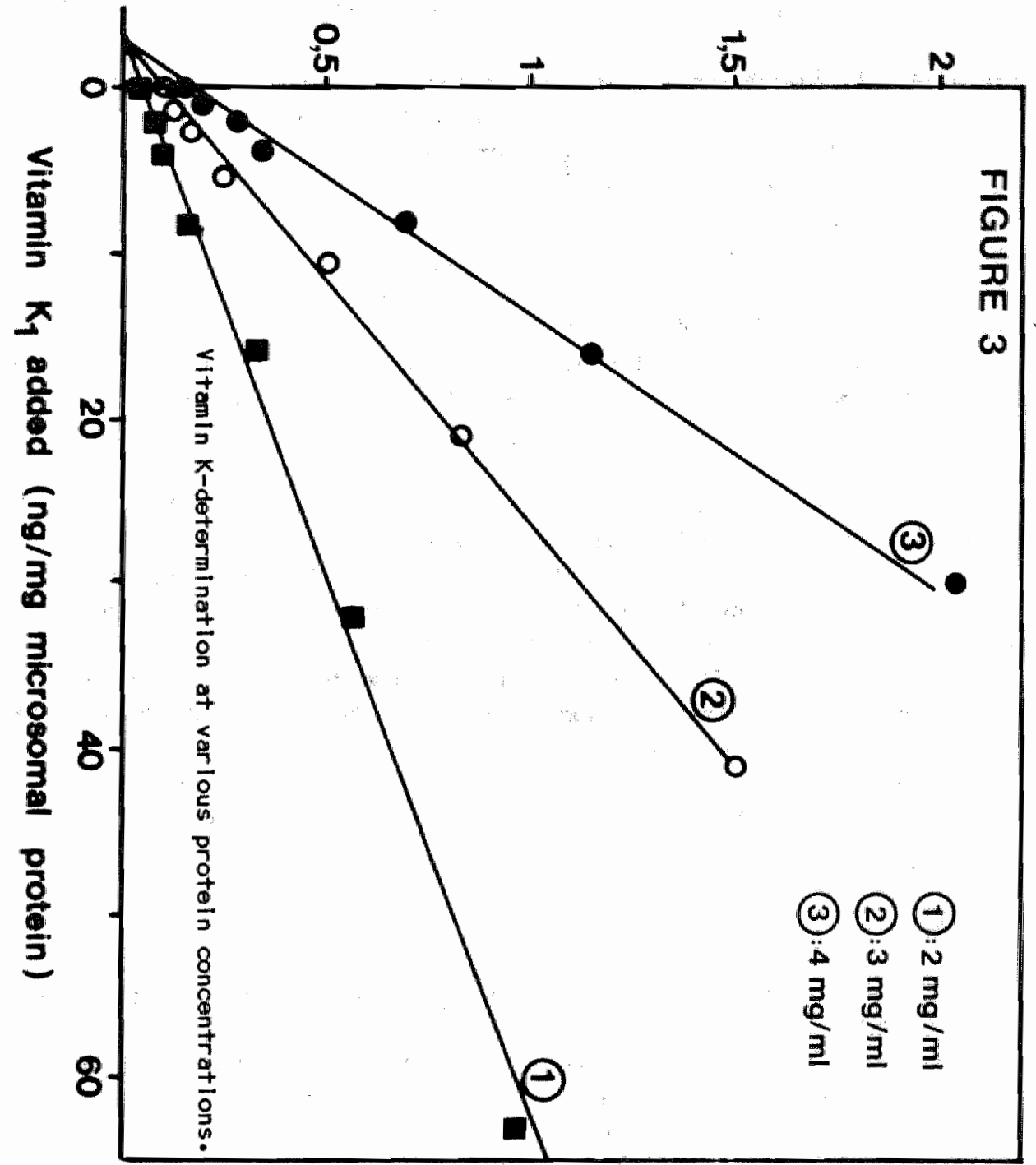


membranes and other (phospho)llpids. However, only the vitamin $k$ avallable for the carboxylating enzyme system, which is present in microsomes, is relevant. Therefore, we developed a new bloassay for the amount of vitamin $K$ present in mlcrosones. The data obtalned were dependent upon the intake of exogenous vitamin $k$. After the administration of $10 \mathrm{mg}$ witamin $k_{1}$ a $4-5$ fold increase was found.

It is difficult to compare the values obtained ith our bloassay in thase found by Haroon using a HPLC assay. In the blaassay phylloquinone (vitamin $\left.K_{1}\right)$ as well as the memaquimones $\left(K_{2}\right.$-vitamins) are measured, whereas in the HPLC assay only vitamin $K_{1}$ is measured. The role of the $K_{2}-v i t a m i n s$ in the carboxylation reaction is less thoroughly investigated than that of phylloquinone. In one report (10) It is suggested, that on a molar basis some of the $K_{2}$-vitamins are considerably more active than vitamin $K_{1}$. Another important difference is the fact that in the HPLC method extracts are prepared of whole liver tissue, whereas in our bloassay microsomes are used. At the moment it is unknown how witamin $k$ is distrlbuted over the several llpid components of the liver cell. It would also be of interest to know if the distrlbution of vitamin $k$ in the Ilver cell is different during vitamin $K$ deficlency and what is the minlimum requirement of vitamin $k$ needed for full carboxylation. We have also studled a few newborn rat liver microsomal fractlons. There are at least 2 reasons, why lower values are to be expected in newborns. First, the placental transport of vitamin $K_{1}$ is 10w (11). Secondly, it may be that the distribution of vitamin $k$ in the varlous organs differs from that in adults, since for Instance the rapidiy growing newborn bone tissue consumes high amounts of vitamin $k$ for the carboxylation of osteocalcin.

In a prellminary experiment we found indeed lower vitamin $K$ concentrations (50\%). These data must be confirmed in a llarger group of animals, before they can be regarded as conclusive.

\section{References}

1. Suttle, J.W. Vitamin K-dependent carboxylase. Ann. Rev. Blochem. 54, 459 (1985)

2. Stentlo, J., Fern llund, P., Egan, W*, Roepstortt, P. Vitamin K-dependent modiflcations of glutanic acld residues in prothrombin. Proc. Natl. Acad. Scl. USA, 71, 2730 (1974)

3. Vermeer "C., Hendrlx, H., Daemen, M. Vitamin K-dependent carboxylases from non-hepatlic tissues. FEBS Lett. 148, 317 (1982:

4. Matschiner, J.T., Dolsy, E.A. Bloassay of vitamin K in chlcks. J. Nutr. $90,97(1966)$

5. Wilson, A.C., Park, B.K. Quantitative analysis of pharmacologlcal levels of vitamin $k_{1}$ in rabblt plasma by high performance liquid chromatography. J. Chromatogr. 277, 292 (1983) 
6. Shearer, N.J., Barkhan, P., Rahlm, S., Stlmmler, L. Plasma vitamin K, In mothers and their newborn bables, Lancet 11, 460 (1982)

7. Langenberg, J.P., TJaden, U.R. Improved method for the determination of wtamin $K$ in human $p$ lasma with electrofluorimetrlic reaction detection. J. Chromatogr. 289, 387 (1983)

8. Lowry, O.H., Rosebrough, N.J., Farr, A.L., Randall, R.J. J. Blol. Chem. 193,265 (1951)

9. Haroon, $Y_{*}$. Hauschka, P.V. Application of high-performance llquid chromatography to assay phylloqulnone (vitamin $K_{1}$ ) in rat IIver. J. of lipld Research, 24, 48 (1983)

10. Matschiner, J.T., Taggart, W.V. Blo-assay of vitamin K by Intracardlall injection in deficlient adult male rats. J. Nutr. 94, 57 (1968)

11. Hamullyák, K., de Boer-van den Berg, M.A.G., Thijssen, H.H.W., Hemker, H.C., Vermeer, C. The placental transport of [ ${ }^{3} H I V I t a m i n K_{1}$ in rats. Thromb. Haemost. 54 (1), 204 (1985). 
CHAPTER 7

REEVALUATION OF SOME PROPERTIES OF FIBRINOGEN, PURIFIED FROM CORD BLOOD OF NORMAL NEWBORNS

K. Hamulyák ${ }^{1}$, W. Nleuwenhulzen ${ }^{2}$, P.P. Devllïe ${ }^{1}$ and H.C. Hemker ${ }^{1}$ 
In this study we compared some properties of flbrinogens, obtalned from normal adult and umbllical cord plasma. Flbrinogen preparatlons were made under conditlions, which minimize proteolytlc breakdown in vitro. We were not able to denonstrate any differences between both purifled fibrinogens as to the effects of $\mathrm{pH}$ and lonlc strength on its cllotting propertles, the $K$ in for thrombin, SDS palyacrylamide gellelectrophoresis behaviour or carbohydrate content.

However, the phosphorus content of cord fibrinagen was 3-4 times higher than that of adult flbrinogen.

The accellerating effect of calclum on the thromblm clotting time was more pronounced for newborn cord plasma and for purlfled card flbrinogen preparations as compared with adult fibrinogen. Thls might be explained by the hlgher phosphorus content of the cord flbrinogen molecule.

The thrombln clotting tlme of bath purlfled adult and cord fibrinogen was markedly prolonged, when Increasing amounts of flbrinogen degradation product fragment $X$ were added to the $f$ lbrinogen solutions under conditions with high $\mathrm{pH}$ or high lonic strength.

At high $\mathrm{pH}$ the effect of adding fragment $X$ was more pronounced in cord flibrinogen preparations. Therefore, mixtures of purlfied flbrinogen and fragment $X$ have several propertles in common with fetall fibrinogen.

These observatlons show, that sone of the properties that have been attributed in the literature to a distinct fetal fibrinogen can be caused by the presence of fragment $x$ in the cord fibrlinogen preparations.

Introduction

The possible existence of a distinct fetal fibrinogen was first reported by Bursteln and coworkers in 1954 (1). They compared some optical and mechanlcal propertles of clots of newborn and adult flibrin and found that a clot of flbrin of newborns was more transparant and less compresslble than a clot of fibrin of adults. The difference was relatively pronounced at pH 8.6 but hardly detectable at pH 6.9. Künzer (2) noted In 1961 that whereas the level of most clotting factors was low, the level of flbrinogen in the newborn was usually the same as in the adult, however künzer also noted differences in propertiles. He postulated a functionally different flbrinogen in the newborn with an accelerated fibrinogen-flbrin transition. witt (3-9) Isolated fibrlinogen from human umbllical cord blood.

She found significantly retarded thrombln-catalyzed conversion of cord fibrinogen to fibrin at pH's around 7. The dlfference was even more pronounced at $\mathrm{pH}$ 8.5. Elactronmicroscoplc comparison of fetal fibrin clots with those from adults showed shorter and thinner flibers, whlch might be a corrolary of the old observation that the fibrin clots in newborn plasma are more transparant $(8,9)$. 
Galanakis (10-12) emphaslzed the Importance of the solvent condlitions, especially of the lonlc strength in the testing systems. He found that relatively high lonlic strengths prolong the thrombln elotting tine of cord flibrinogen more than that of adult fibrinogen. In agreement with Gullilin (13) he found a slower rate and a lower degree of aggregation of fetal fibrin monomers as compared with adult fibrin monomers at high lonle strength. Teger-Nilsson (14) found only a slightly lower aggregation rate of fetal fibrin monomers and no signiflcant prolongation of the thrombin clotting time at a physlologlcal lonlc strength and pH. This was also reported by Krause (15). Teger-Nilsson found no dlfferences between the two types of flbrinogen on polyacrylamide gelelectrophoresis and mapplng of tryptic peptides of reduced and alkylated polypeptide chalns.

wit and coworkers (3-9) described extensively the molecular properties of purifled cord fibrinogen. The overall aminoacld composition of nowborn flibrinogen was virtually the same as that of adult flibrinogen. On the basls of data obtained by fingerprinting tryptic digests, she postullated that at least throe peptides differ in newborn as compared with adult fibrinogen. Fetal flbrlnogen has been reported to contain the same anount of hexose, but almost twice the amount of phosphorus of adult flbrinogen (5). This probably did not explain the functional differences because enzymatlc dephosphorylation did not correct the functional properties of fetal flbrinogen. On DEAE cellulose column chromatography the major flbrl nogen peak from newborn flbrinogen preparations eluted somewhat later than those obtalned from adult materlat. The apparent $K_{\text {m }}$ for thrombin was lawer for fetal than for adult flbrinogen, suggesting a greater affinlty of thrombin for fetal than for adult fibrlnogen.

In 1979 Galanakis reported that partial removal of slalle acid shortened the prolonged thrombin clotting time of fetal flarinogen. He found the siallc acid content of tetal flbrinogen to be higher than that of adult flibinogen (12). This was also reported by Lane, who described a markedly different carbohydrate composition of fetal fibrinogen, particularly an Increased slallc acid content (16). Galanak/s reported in 1977 that a mixture of adult and fetal fibrinogen is found in the cord plasma of full-term infants. In prenature infants there is rallativelly more fetal flbr Inogen (11).

Mills and Karpatkin (17) challenged the exlstence of a distinct fettal flibrinogen. They concluded that the delay of clotting of cord flbrinogen is due to a greater content of preformed fibrin in these preparatlons and could not relate the heterogenelty of adult flibrinogen to the persistance of a fetal flbrinagen. Also other authors questloned the existence of: distinct fetal flbrinogen $(18,19,20)$. Loly (21) could not find any difference between adult and fetal sheep-fibrinogen.

Altogether there is still a lot of controversy about the propertles of the so called fetal fibrinogen and even its existence is doubted. Indred the varlations in experimental results can be explained by differences in 
purlfication mathods and solvent conditlons in the testing systens. Also artefacts, Introduced by IImited proteolys is in vitro cannot be precluded. We therefore reexamined the problem under conditions, where speclal care was taken to prevent proteolys is in witro.

We also measured the Influence of adding Increasing anounts of fibinogen degradattlon product fragment $X$ to see whether the reported differences between preparatlons of newborn and adult flbrlnogen could be explained by the presence of degradation products in the former.

\section{Mater lalls and Methods}

Blood samples were obtalned from the umbllical cords of normal full-tierm Infants by venapuncture, Immedlately after clamplng the umblilical cord. The Apgar score of the Infants was more than 7 after one minute, the pH of the umbllical veln blood greater than 7.20 and the blrth welghts were all in the normal range. There were no slgns of fetal distress before parturltion and no mecroscoplc alterations of the placenta and the umbllical cord were observed.

The mothers did not recelve any medlcation, reported to posslbly influence the haemostatlc reaction in the child.

The flirst few ml's of cord blood after a clean venapuncture were discarded. The bllood was then collected in an antlcoagulant medium containing $1 \%(w / w)$ $\mathrm{Na}_{2}$ EDTA, $0.96(\mathrm{w} / \mathrm{w}) \mathrm{NaCl}$ and $400 \mathrm{~K} \cdot \mathrm{l} . \mathrm{U}$. Trasylol per $\mathrm{ml}$. 9 vollumes of blood were mixed wth 1 volume of the antlcoagulant medlum.

Immedlately after blood sampling 1 \& $(v / v)$ dl-Isopropylphosphofluorldate (DFP) solution $10.1 \mathrm{M}$ in dry isopropanoll was added to prevent proteolysis in vitro. The samples were centrlfuged for 15 minutes at $1500 \mathrm{~g}$ in a swing-out rotor. The plasma was centrifuged at $20.000 \mathrm{~g}$ for twenty minutes to renove blood platelets and other partlculate ellements.

The plasma was then dilluted to 1.5 times the original bload volume with a phosphate buffer, $0.15 \mathrm{M}, \mathrm{pH} 7.5$, contalning per 11 ter $22.3 \mathrm{gr} \cdot \mathrm{K}_{2} \mathrm{HPO}_{4}, 3$ $\mathrm{gr} . \mathrm{KH}_{2} \mathrm{PO}_{4}, 1.1 \mathrm{gr} \cdot \mathrm{Na}_{2}$ EDTA, $0.1 \mathrm{gr} \cdot \mathrm{NaN}_{3}$ and $20.000 \mathrm{~K} \cdot 1 . \mathrm{U}$. Trasylol. At each step $1 \%(v / v)$ DFP solution was added.

Cord plasma"s of five newborns were comblned to give a pool of approximately $100 \mathrm{ml}$ plasma and stored at $-20{ }_{\mathrm{C}}$ unt 111 further use. The cord blood was obtalned with the kind coopperation of the staff of the Midwivery School in Heerlen (Head: Dr. R. Oomers).

Adult blood was collected and plasma prepared from healthy donors as descr lbed above.

Purll loation of Flbrinogen:

Fetal and adult fibrinogen were purlfied from $100 \mathrm{ml}$ cord plasma and adult pllasma respectively, by the procedure to be descrlbed below. The plasma was applled to a Sepharose-1ysine column $(2.8 \times 13 \mathrm{~cm})$ to remove plasminogen. The eluate was brought to $25 \%$ saturation in $\left(\mathrm{NH}_{4}\right)_{2} \mathrm{SO}_{4}(13.9 \mathrm{gr} \cdot / 100 \mathrm{ml})$, stirred for one hour at $4{ }^{\circ} \mathrm{C}$ and centrlfuged for twenty minutes at $3000 \mathrm{~g}$. The 
precipltate was dissolved in phosphate buffer to 1.5 times the or liginal blood volume and agaln preclpltated at $25 \%\left(\mathrm{NH}_{4}\right)_{2} \mathrm{SO}_{4}$ saturation. Th/s precipitate was dissolved in a minimum volume of phosphate buffer and gel flltered on a Sepharose 63 collumn $(2 \times 120 \mathrm{~cm})$ at $4{ }^{\circ} \mathrm{C}$. The second peak (absorbance at $280 \mathrm{~nm}$ ) contains virtually pure flbrinogen. The pur iflcation procedure has been described in detall elsewhere (Van Ruyven-Vermeer et al. 22).

SOS polyacrylamide gelelectrophoresils was performed according to standard procedure ith and ithout B-mercaptoethanol (23).

Thrombin clotting time: Fibrinogen concentrations were adjusted to $1 \mathrm{mg} / \mathrm{ml}$ * Al quots of $0.200 \mathrm{mi}$ flibr inogen solutions were prelncubated for 30 seconds at $37{ }^{\circ}$. The reaction was started with $0.050 \mathrm{ml}$ of a bovine thrombin solution ( $5 \mathrm{~N} . \mathrm{I} \cdot \mathrm{H} . \mathrm{U} / \mathrm{ml}$ ) (Roche, Basel) and the clotting time recorded with the use of a Kolle Hook.

The Influence of the pH of the flbrinogen solutlons on the thrombin clotting time was studled by varying the pll by dlalyzing before the experiment against buffers contalning $0.15 \mathrm{M} \mathrm{NaCl}$ and $0.01 \mathrm{M} \mathrm{Tris.} \mathrm{lonlc} \mathrm{strengths}$ were varled in the range of 0.05 to $0.30 \mathrm{M} \mathrm{NaCl}$ at a constant $\mathrm{pH} \mathrm{7.4.} \mathrm{The}$ influence of calcium added to the thrombin solution was also studied. To

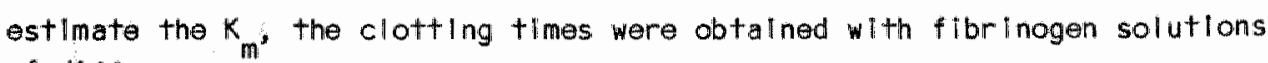
of different concentrations.

Fragment $X$ was prepared by Ilmited plasmin digestion of purlfled adult fibrlnogen and purifled according to W. Nleuwenhullzen and M. Gravesen (24). The effect of adding Increasing amounts of fragment $X$ on the thrombin clotting time of cord and adult fibrinogen was studied, especlally under condlitions with a high $\mathrm{pH}$ and high lonlc strength.

Carbohydrate determination: the carbohydrate analyses were performed essentially as described by Kamerling and Clamp (25). They were carrled out by Drs. J.P. Kamerling, G.J. Gerlling and J.F.G. VI legenthart, Laboratory of Organlc Chemlstry, Unlversilty of Utrecht, Utrecht, The Netherlands. Before analysis samples of flbrinogen were run through a Blogel-P 60 column in $0.15 \mathrm{M} \mathrm{NaCl}$, dialysed extensively agalnst several changes of distllled water and freeze-drled.

Phosphorus determination: phosphorus determinations were carrlad out according to Böttcher (26). Before analysis samples of fetal and adult flbrinogen were dialyzed against several changes of twicendistillied water and freeze-drlled. To check the possibllity that the phosphorus in the flbrimogen arlginates from bound phosphollplds, the flbrinogen preparations were extracted according to the following procedure: $20 \mathrm{mg}$ portlons of fetal and adult fibrinogen in $10 \mathrm{ml} 0.15 \mathrm{M} \mathrm{NaCl}$ were dialyzed agalnst distllled water and freeze-drled.

$10 \mathrm{ml} \mathrm{NaCl}(0.15 \mathrm{M})$ was also dlalyzed and freeze-drled, to serve as a control. To the residues $40 \mathrm{ml}$ methanol: chloroform $=1: 2$ was added and the mixture heated for 15 minutes at $60^{\circ} \mathrm{C}$. After coolling to room temperature 9 $\mathrm{ml} 0.15 \mathrm{M} \mathrm{NaCl}$ was added to each tube and shaken well. 


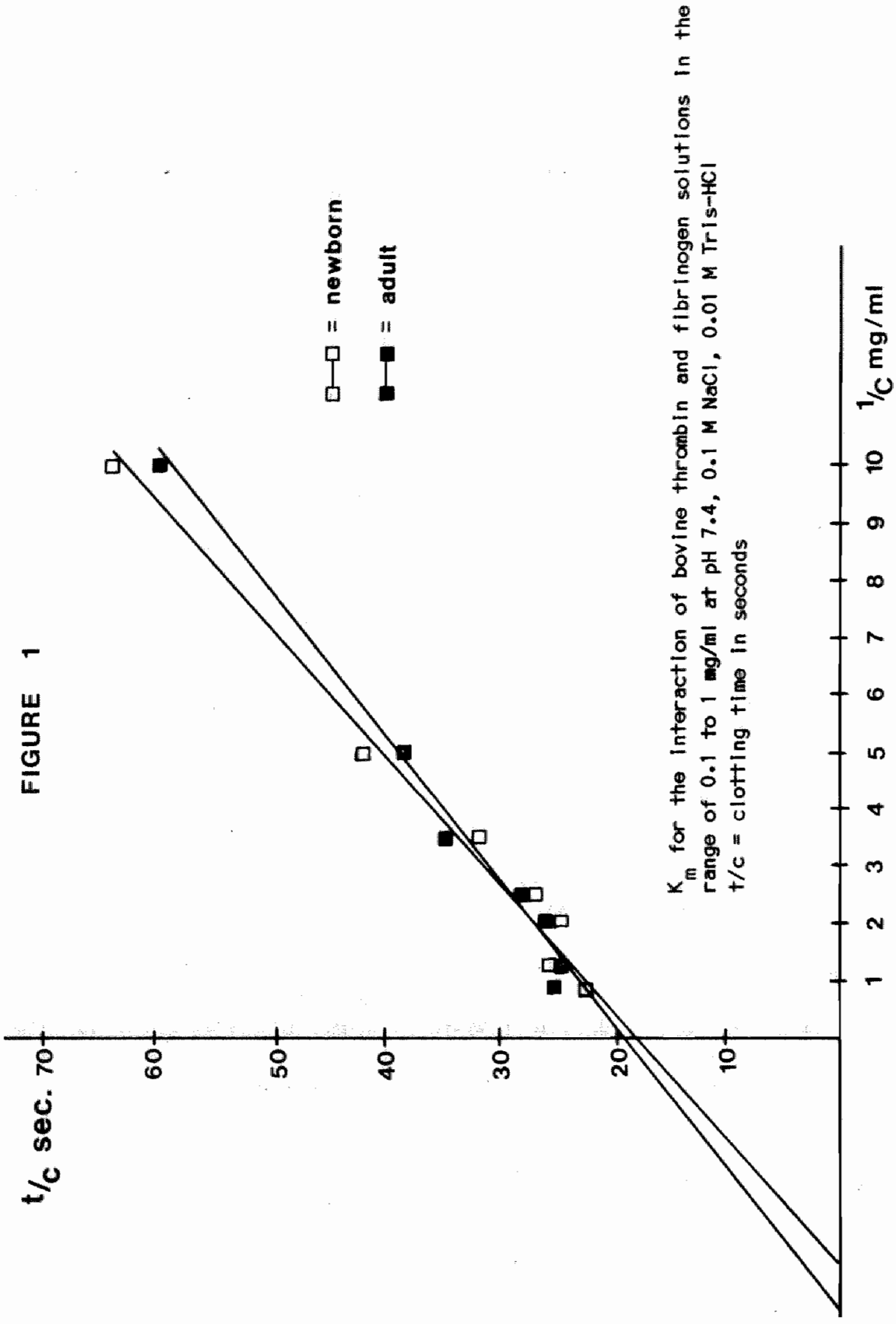


Thrombin clotting time (sec.)

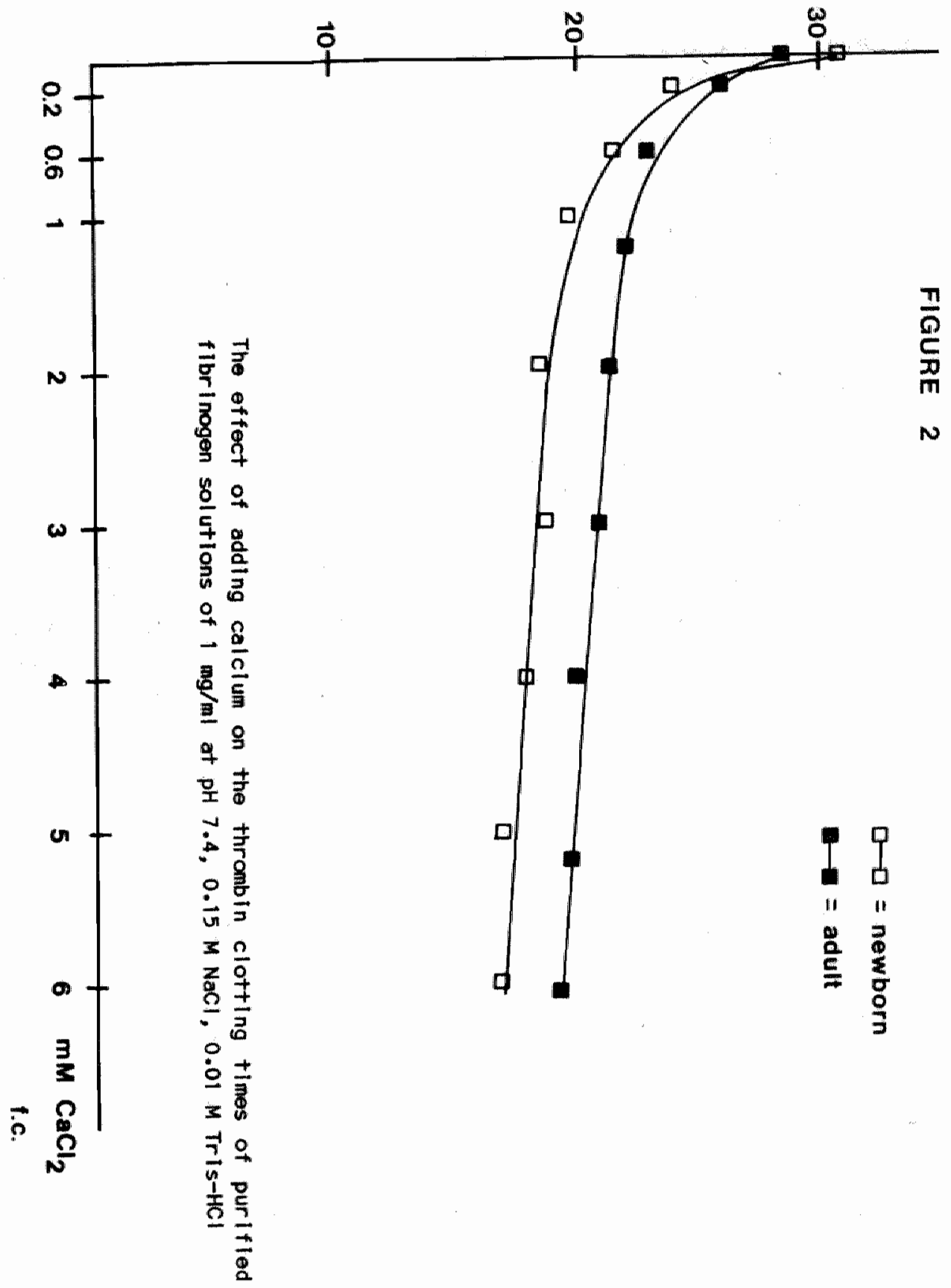


Atter centrifugation to separate the phases, the upper llayers were removed, the botton layers were washed ance with methanol: chloroform: water = 48:4:47 and centrlluged again. The remalning bottom layers were evaporated under a stream of nitrogen, taken up in $0.5 \mathrm{ml}$ chloroform and the amount of phosphol iplds determined according to van Gent (27).

Rasults and D/scusslon

In contrast with some reports in the literature we found no signiflcant different Influences of the $\mathrm{pH}$ and/or the lonlc strength on the thrombin clotting time of adult and cord flbrinogen (results not shown).

Only at hlgh lonle strength $(0.30 \mathrm{M} \mathrm{NaCl}$ ) and $h$ lgh $\mathrm{pH}(9.0)$, the thrombin cllotting time seems to be sllightly prolonged with cord flbrinogen as compared with adult fibrinagen. However, It is difficult to declde how signiflcant these differences are, since it was alfflcult to assess the cllotiling times accuratelly under these conditlans.

The $\mathrm{pH}$ optimum for the thrombin-catalysed transition of both adult and cord fibrinogen to flbrin was 7.4 .

The $K_{m}$ values for the interaction of thrombin (bovine) with adult and cord fIbrinogen were determined by measuring clotting times with varying flibrinogen concentrations at a fixed thrombin concentration. The results are shown in flgure 1. In this flgure use has been made of the fact, that the clotting time is proportional to $1 / v(w=$ velocity of the overall flbrinogen conversion reaction in an experimental set up)(28). As can be concluded from this flgure, no significant differences could be found between the $K_{m}$ 's of adult and cord flbr|nogen. The values found were 0.70 and $0.62 \mu \mathrm{M}$ respect $\mid$ vely.

Electrophoresis on sDS polyacrylamide gels containilng B-mercapto-ethanol showed no difference between adult and cord flbrinogen (not shown).

TABLE I

Carbohydrate composition of adult and cord fibrinogen

\begin{tabular}{lllll}
\hline & \multicolumn{3}{c}{ nmol./mg } & \multicolumn{2}{c}{ molar ratio } \\
\cline { 2 - 3 } mannose & $\frac{\text { adult }}{40.7}$ & $\frac{\text { cord }}{31.7}$ & $\frac{\text { adult }}{3.0}$ & $\frac{\text { cord }}{3.0}$ \\
galactose & 25.5 & 19.5 & 1.9 & 1.8 \\
glucose & 10.7 & 9.9 & 0.8 & 0.9 \\
N-acetyl glucosamine & 32.3 & 24.7 & 2.4 & 2.3 \\
sliallc acid & 16.5 & 14.5 & 1.2 & 1.4 \\
\hline
\end{tabular}

The carbohydrate compositions of cord fibrlnogen and adult fibrinogen are essentlally the same (table 1) and the results are in accordance with the 
data of Townsend (29) for adult flibrlnogen.

Differences In the slallc acid content, reported in the 11 terature $(12,16)$ were not confirmed.

We could confirm that the phosphorus content is 3 to 4 times higher In cord fibrinogen than in adult flbrinogen (5). The results are shown in table 2 . It could be excluded that this was due to contamination with phosphollplds, because after lipid extraction virtually no phosphorus was found in the extracts.

TABLE $\|$

Phosphorus content of adult and cord flbrinogen (molar ratlo)

cord fl brinogen:

$P:=1:(10.9+0.2)$.

adult flbrinogen:

$P=1:(2.9+(0.4)$.

We also studled the Influence of calclum on the thrombin-catalyzed transition of fibrinogen to flbrln. The results are shown in flgure 2 .

From this it can be seen that the procoagullant effect of adding calclum to the thrombin solution is more pronounced in the preparations of cordflibrlinogen than in those of adult flibrinogen.

Some of the properties, ascribed to a distinct fetal fibrinogen specles, might be explained by the occurence of contaminants, especially fibrinogen breakdown products, in some cord fibrlnogen preparatlons. These might have been formed in vivo and/or in vitro. We trlod to minlmize flibrlnogen proteolysis in viltro in our pur l fication procedure.

No fibrinogen degradation products were abserved in our purlfied cord and adult flibrinogen preparations. Thls indicates that such degradation products do not occur in vivo in detectable amounts or that they have bean lost during the puriflcation of the flbrinogen. The latter posslbllity would lead to a correction of the apparent abnormallitles observed with cord plasma as a result of the purlfication.

The occurence of degradation products in newborn blood in wiwo is likely, since it is known that in the slck newborn a marked degree of diffuse intravascular coagulation is quite comon, probably rellated to hypotension, hypothermia, hypoxla, acidosis, poor tissue perfusion, hepatic Immaturlty and a poorly developed retlculoendothellal system, which may prevent adequate clearing of activated coagulation factor's and therefore enhance the sequala of diffuse Intravascular coagulation.

The enlhanced flbrinolytic capaclty of cord blood of normal newborns is well 
$t / c$
$\sec$

FIGURE 3

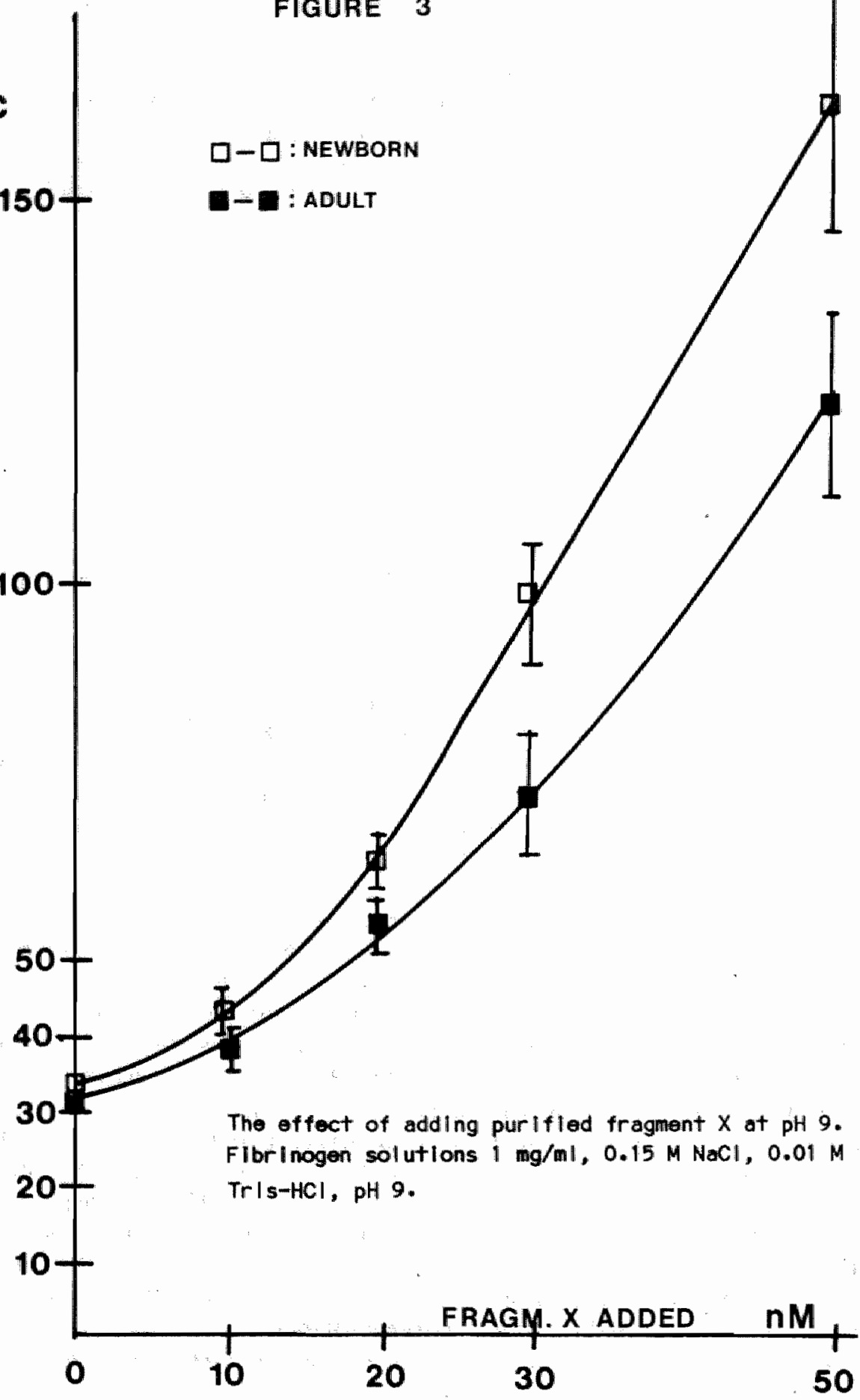




\section{FIGURE 4}

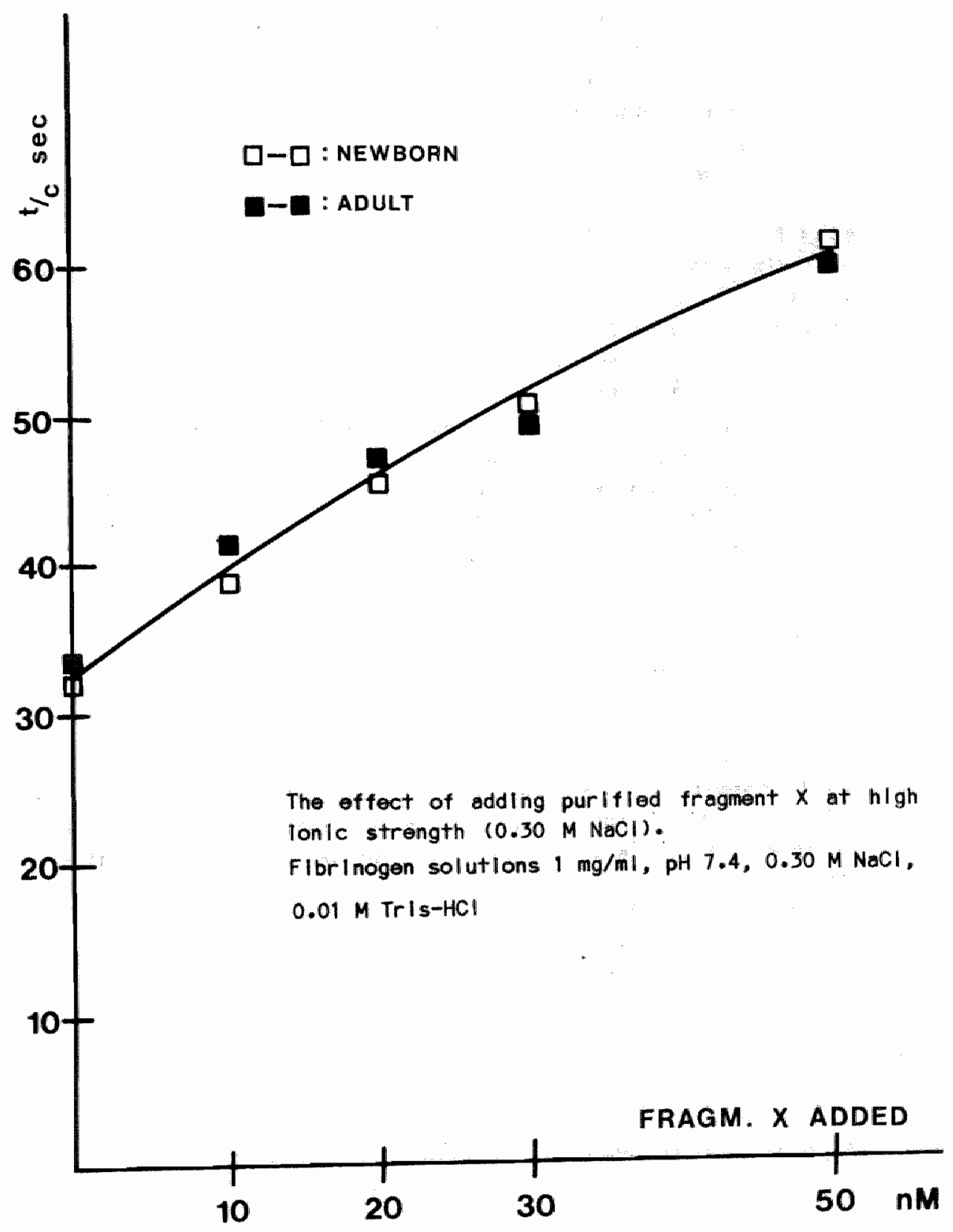


documented in the IIterature (30) and may be the cause of some proteolysis of flibrinogen.

If demonstrated, the presence of degradation products in cord plasma could explain some of the propertles, ascrlbed to fetal flbrlnogen. It Is known, that fragment $x$, for instance is a potent inhibitor of the action of thromblin on fibrinagen and polymerlzation of flbrin monomers (24). In nearly all newborn cord plasma's the thrombin clottting time is prolonged. According to our data, this prolongation cannot be attributed to different clotting propertles of purlfled cord flbrlnogen, but milght well be explained by the presence of for Instance fragment $X$. As at the time of this study no speciflc and sensitive methods were avallable to demonstrate the presence of low levels of some of the high molecular welght breakdown products directly in plasma, we studled the influence of increasing amounts of added flibrlnogen breakdown product fragment $x$ to the solutllons of purlfled flbrinogens, especlally under conditlons with a hlgh $\mathrm{pH}$ and high lonle strength.

As can be seen in figure 3, the thrombin clatting time of cord fibrinogen appeared to react stronger to the additlion of fragment $X$ than adult fllbrinogen at pH 9. No differences were recorded between the two types of fllbrinogen at high lonlc strength, when increasing amounts of fragment $X$ were added to the fibrlinogen solutions. This is shown in figure 4.

These results suggest that some of the clotting properties, ascrlbed In the Ilterature to fetal fibrinogen may be due to a contamination with degradation products such as fragment $x$.

Witt postulated (9) that the synthesis of fatall florinogen lasts only for 7-8 days after birth. We suggest, that after that perlod the florino(geno)Iysis has returned to normal levels and that degradation products such as fragment $X$ have been cleared from the newborn bllood.

Our results clearly conflirm the higher phosphorus content in purlfled cord flbrinogen than in adult flbrinogen. Little or nothing is known about the role of phosphorus in the fibrinogen molecule.

Blomback (3i) showed that the phosphorus in adult fibrinogen is covalentiy bound In the form of O-phosphoser Ine and partly found in fibrinopeptide A. Accordling to the data of Wltt enzymatlc dephosphorylation had no effect on the functional properties (5).

The hlgher phosphorus content may play a role in the more pronounced effect of calclum added to the thrombin solution, on the thrombin cllotting time in purlfled card fibrlnogen as compared with adult fibrinogen. At present experlments are carrled out to flind possible correlations between levels of plasminogen activators and prolonged thrombin clotting times of cord plasma 
1. Burstein. M., Levi, 5., Walter, P. Sur l"exlstence du flbrlnogène foetal. Le Sang 25, 1021 (1954)

2. Künzer, Wi: "Fetales Flbrinogen". Klinische Wochenschrift 39, 536 (1961)

3. Witt, 1., Müller, H., Künzer, W. Evidence for the exlstence of fetal fibr Inogen. Thromb.Dlathes. Haemorrh. 22, 101 (1969)

4. Witt, 1., Karltsky, D., Müller, H., Künzer, W. Peptidmuster von hochgerelnigtem Flibrinogen aus neugeborenen- und erwachsenen blut. Schwelz.Med.Wschr. 42, 98, 1684 (1968)

5. Witt, 1., Müller, H. Phosphorus and Hexosecontent of human fotal flbrinogen. Biochimica Blophysica Acta. 221, 402 (1970)

6. Witt, 1., Hasler, K. Influence of organically bound phosphorus in fetal and adult flibrlnogen on the klnetics of the interactlon between thrombin and fibrinogen. Blochimica ot Blophyslca Acta. 271, 357 (1972)

7. Witt, 1., Tesch, R. Untersuchungen zur Struktur des fetalen Flbrinogens. Blut. 38, 54 (1979)

8. Tesch, R., Trolp, R., Wltt, 1. Electronmlcroscoplc studies on the fetal fibrin clot. Thrombosis Research. 16, 239 (1979)

9. Witt, 1. Besonderhelten des Blutgerlinnungs und Fibrlnolyse Systems bei Neugeborenen. Fibrilnolyse, Thrombose, Hämostase. Verhandlungen des I.Kongresses fgr Thrombase und Blutger Innung. 212 (1980)

Herausgober: E. Deutsch, K. Lechner, F.K., Schattauer verlag Stuttgart-New York.

10. Galanakis, D.K., Mosesson, M.W. Evaluation of the role of in vivo proteolysis ( $f$ brinogenalysis) in prolonglng the thrombin time of human umblilical cord fibrlinagen. Blood, 109 (1976).

11. Galanakis, D.K., Mosesson, M.W. Comparative studies on fotal fibrinogen from full-term and premature infants. Thrombosls and Haemostas is, 42, 79 (1979)

12. Galanakis, D.K., Mosesson, M.W. Correction of the delayad fibrlin aggregation of fetal flbrinogen by partlal remowall of slallc acld. Thrombosis and Haemostas ls, 42, 79 (1979)

13. Gulllin, M.C., Menaché, D. Fetal Flbrlnogen-Flbrin Umwandlung $1 \mathrm{~m}$ Nabol venenblut. Med. Well, 48, 26 (1975)

14. Teger-nllsson, A.C.*, Ekel und, H. Flbrinogen to flibrlin transformation in umblilcal cord blood and purlfled neonatal flbrliogen. Thrombosls Research, 5, 601 (1974)

15. Krause, W.H., Maus, W. Untersuchungen zur Flbrlnogen-FIbr in Umwandlung in Nabelvenenblut. Med.Welt 48, 26 (1975)

16. Lane, D.A., Allen, A.K., Markwlck, J., Mackie, 1., Thompson, E*, Owen, J. Carbohydrate composition and catabolism of flve abnormal flbrinogens. Thrombosis and haenostasis, 46(1) 181 (1981) 
17. Mills, D.A., Karpatkin, S. Heterogenelty of human adult and fetall flarlnogen: Detection of derlvatives Indicative of thrombin proteolysis. Blochlmica et Blophysica Acta. 285, 398 (1972)

18. Von Felten, A., Straub, P.W. Coagulation studles of cord blood with special reference to fetal flbrlnogen. Thromb.Diathes.Haenorrh. 22, 273 (1969)

19. Gmür, J.P., Von Felten, A., Straub, P.W. Blutgerinnung und Fibr llnolyse Im Nabel schnurbl ut. Thromb. Dl athes. Heamorrh, 23, 82, 1970

20. Gmür, J.P., Von Folten, A., Straub, P.W. Bl utger Innungsuntersuchungen In Nabelvenenblut. Fetales Flbrlnogen? Schwelz.Med.Wschr. 100, 299 (1970)

21. Loly, W., Isrä̈ls, W.G., Blshop, A.J., Israëls, E.D. A comparative study of adult and fetal sheep flbrinogen, sulf-flbrinogen and flbrinogen degradation products. Thromb.0iathes.Haemorrh. 26, 625 (1971)

22. Van Ruyven-Vermeer, 1.A.M., Nleuwenhulzen, W. Purlfficatlon of rat flbrinogen and Its constituent chalns. Blochem.J. 169, 653 (1978)

23. Weber, K., Osbarne, M. The rellabllity of molecular welght determinations by dadecylsulphate-polyacrylanide gelelectrophoresis. J.of Blol. Chemlstry. 244, 4406 (1969)

24. Nleuwentulzen, W., Gravesen, M. Antlcoagulant and calclumblinding propertles of high molecular welght der I vatives of human fibrlinogen, produced by plasmin (fragments $X$ ). Blochlmica Blophyslca Acta 668, al (1981)

25. KamerIIng, J.P., Gerlling, G.J., Vllegenhart, J.F.G., Cil amp, J.R. Blachem.J. 151, 491 (1975)

26. Bättcher, C.J.F., Van Gent, C.M., Prles, C. Anal.Chlm.Acta. 24, 203 (1961)

27. Van Gent, C.M. In: Protldes of the Blologlical Flulds vol. 19 IH. Peoters ed.) New York, Pergamon Press 175 (1972)

28. Hemker, H.C., Hemker, P.W., Loellger, E.A. Kinetic aspects of the interaction of blood clatting enzymes. Thrombos.Dlathes. Haemorrh. 13, 155 (1965)

29. Townsend, R.R., Wlker, E.H., Yu-Tehl, I., Lalme, R.A., Bell, W.R. and Loo, Y.C. Carbohydrate structure of human flbrinogen. Use of 300-MH2 H-NMR to character lze glycos Idase-treated glycopeptides. J. of Blol .Chemlstry, 257, 16, 9704 (1982)

30. Ekel und, H., Hedner, U., NIIIson, I.M. FIbrlnolysls in newborns. Acta paedlatr lca Scand Inavlica, 59, 33 (1970)

31. Blombäck, B., Blombäck, M., Edman, P., Hessel, B. Human fllorlinopeptldes isolatlon, characterization and structure. Blochimica et Blophysica Acto 115, 371 (1966) 
CHAPTER 8

A NEW CASE OF A CONGENITAL COMBINED HYPO- DYSFIBRINOGENAEMIIA

K. Hamulyák, A.D. Mulller and H.C. Hemker

Department of Blochemistry, Faculty of Medicine, Universitty of Limburg, Maastrlcht, The Netherlands 
In thlis paper we present the prelliminary results of a study of a new case of a comblned hypo- dysfibrlnogenaemla. Because of an umbllilical stump haemorrhage two days after birth, a screenling proflle of the haemostatlc mechanlism was performed on a female child of dutch origin. Thls showed a very low amount of thrombin clottable flibrinogen, measured according to the method of Cllauss (20). No other abnormallties were found. Fibrin(ogen) degradation products could not be detected in plasma, using specific monoclonal antibodies. The reptllase cllotting time was also prolonged, compared with normal values found at her age. However, reptillase Induced flibrlm clot formation appeared to be less abnormal than thrombin Induced flibrin clot formation.

In mixtures of normal plasma and plasma of the propositus no inhibitory effect on the thrombin clotting time of normal plasma was found. Immunological studies showed that the amount of fllbrlinogen related antigen was at least 2.5 fold higher than the amount of thrombin clottable flbrinogen. The discrepancy was much higher in "heat defibrinated" samples, suggesting that the heating procedure leads to a major change in the antigenic sltes of the abnormal fibrinogen moleculle. Crossed Immunoelectrophoresis showed also an abnormal form and a slightly different pasition of the preclpitation arc of the plasma of the propositus in the absence and presence of calcium.

Untll now (age 3) our patlent has remalned asymptomatlc and her development was normal. This case underllines the hypothesls of Ménaché (1) that many of the hypofibrinogenaemlas are in fact partly dystibrinogenaemlas.

it is remarkable that in our case the famlly history appeared to be negative. This is very unusual, as most of the hypo- and dysfibrinogenemlas follow a daminant inherltance pattern. For practical reasons we decided to postpone a definltive purification and characterlzation of the fllbrinogen of the propositus and her famlly.

\section{Introduct Ion}

Congenttal flbrlmogen anormalitles cover great varlety of rare disorders, Including aflbrlnogenaemla, hypoflbrlinogenaemla and dysflbrlinogenaemla. Aflbr Inogenaemla and hypofibrlnogenaemla are characterized by a lack or Important decrease of clrcullating functionally normal fibrinogen, whereas dysfibrinogenaemla is characterlzed by the presence of qualltative abnormal and functionally defective fibrinogen molecules. Dysfibrinogenaemla is usually ciasslfled according to the functional defect present, for Instance abnormalities in the release of the flibrinopeptides, abnormal polymerlzation of flbrin monomers, abnormal crossllinkling of fibrin by factor Xllla or abnormal sensitivity to plasmin. Recently it has been postulated that hypofibrinogenaemla is not necessarlly a partial deflclency 
of the normal flibrinogen nolecule only; but that in a number of cases it should be classlfled as a dysflbrinogenaemia, or as a comblnod hypodysfibr inogenaemla (Ménaché 1983) (1). Slnce the flrst well documented case of a dysfibrinogenaemla was published in 1963 (2), approximately 100 familles have been described $(1,3,4)$. With the exception of flbrinogen aslo 1 (5), in whlch conversion is accelerated, flibrlnogen to florin conversion is delayed in abnormal fibrinogens, the common finding beling a prolonged thrombin clotting time (1). The molecular defect has been characterlzed for several among them. It often involves a single anino acid substitution in the Ac chain $(6-11)$. All these flbrinogens exhlbit delayed release of flbrinopeptide A. No single amino acid substitution has been reported so far in the $B B$ or the $\gamma$ chalns. Other structural defects have also boen descrlbed, for lnstance a segmental deletion in the carboxy ferminal and of

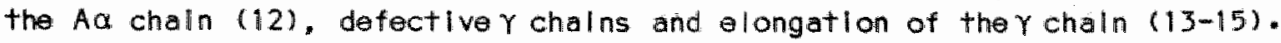
In these abnormal fibrinogens, the flibrin monomer aggregation is delayad, whereas the release of the flbrinopeptides is normal. Also other abnormal lt les have been described in these verlants of human fibrlnogen, such as an Inhibitory effect on the thrombin clotting time of normal plasma and a hypercatabolism of flbrinogen whlch may or may not be compensated by enhanced fibrinogen synthesls (28). Aflbrinogenaemla has been descrlbed for the first time in 1920 (16). The total number of famllles reported since that time is around 70 (1). Hypofibrlnogenaemla, flrst recognized in 1935 (15) has a much lower incldence (1). Congenltal abnormalities of fibrinogen accur in the same frequency in both sexes. The mode of Inheritance is autosomal dominant for the group of the aflorinogenaemias. In the case of hypoflbrinogenaem la the mode of inherltance is less well deflned, probably as a result of the heterogenelty of this disorder (1). In some famllles, absence of consanguinlity between the parents, haemorrhaglic symptoms in one of the parents or low fibrinogen levels in only one of the parents, favor dominant transmission. In other famllles a recessive transmission has been postulated based on consangulnity betwaen parents, low flbrinogen levels and lack of clinlcal symptoms in both parents. In dystlbrinogenaemla the mode of Inherltance is autosomal dominant, except for fibrinogen Parma and flbrlinogen Valencla $(18,19)$. In this report we present the prellminary results of a study of the fibrinogen of a chlld, that at birth showed a remarkable low level of thrombin clottable, flbrimogen, measured according to ref. 20 .

Case hilstory

The propositus was born in january 1983 as the second female chilld of a 28 year old mother and a 29 year old father. Pregnancy and parturition were normal. Durling pregnancy the mother used an oral lron therapy as suppletion. No reasons could be found to assume intoxlcations known to Influcence the haemostatlic mechanism in the offspring. 
The chlld was born to terme vla vaginal del lvery, birth weight 3400 gram, length $50 \mathrm{~cm}$, the Apgarscore was 9 after 1 minute and 10 after 5 minutes. A routlne physlcal examination showed no abnormalltios. Two days after birth the umbllical stump started bleeding, Wthout evidence for trauma, infaction or any other local pathological process. There were no other bleading sltes and a physlcal examination showed no other abnormallties at that the. The child was fed with breastmilk and had recelved no medication or vitamin suppletion. The bleeding was treated locally by suturing and local pressure. Because of the umblllcal stump haemorrhage a screenling proflle of the haemostatlic mechanlsm was performed in the routine laboratory of the hospltal were delivery had taken place. The results of this screenling are summarlzed in table 1.

TABLE ।

\begin{tabular}{lll}
\hline & Patlent & $\begin{array}{l}\text { Normal values two } \\
\text { days after birth }\end{array}$ \\
\hline heematocrit & $54 \%$ & $60 \%+6.4$ \\
bleeding time & $2,15^{\prime \prime}$ & $1-4^{\prime}$ \\
thrombocytes & $317^{9} \times 10^{9} / 1$ & $150-400 \times 10^{9} / 1$ \\
thrombotest & $25 \%$ & $20-60 \%$ \\
aPTT & $65^{\prime \prime}$ & $40-70 \mathrm{~m}$ \\
F VIII & $76 \%$ & $80-120 \%$ \\
flbr Inogen (Clauss) & $0.2 \mathrm{~g} / 1$ & $1.4-3.2 \mathrm{~g} / 1$ \\
\hline
\end{tabular}

Durling 8 days the bleading slte remained oozlng. Until now no recurrent bleeding problems have occurred and the development of the chlld was entlrely hormal. Impalred wound healling was not reported. It was remarkable that the famlly history appeared to be negative, although on the father's slde newborn chlld dled a few days after blrth, without a known cause. There was no known consangulnity with in the famliy. We relnvestigated the patient at the age of 3 months and one year as well as the only slbling (temale, 2 years) and both parents.

\section{Materlals and Methods}

Blood was obtalmed by a clean venapuncture. After dlscarding the flrst few ml's, blood was collected ( 9 vallumes) In a plastic tube containing anticoagulant (1 volume, $3.2 \%$ disodium citrate dlhydrate) for the coagulation studles and in a mixture of diluted human thromboplastin. Trasylol and EACA for the determination of fibrin(ogen) degradation products. The blood was centrlfuged $2000 \times \mathrm{g}$ for 15 , and platelet free plasma was obtalned by 
centr lfugation for $30^{\prime}$ at $20.000 \mathrm{~g}$ at $4^{\circ} \mathrm{C}$. The plasma's were stored at -70 ${ }_{C}$ untll further use. Prothrombin time (PT) was measured using a human brain thromboplastin, prepared in our laboratary. The partial thromboplastin time (PTT) was measured with a aPTT reagent purchased from Dade,

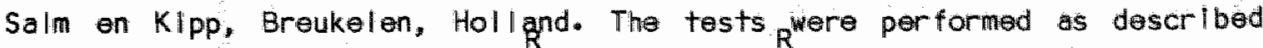
prevlously $(21,22)$. Thrombotest and Normotest were performed according to the manufacturers prescrlption (Nyegaard, Oslo, Norway) as descrlbed by Owren (23). Bovine thromblin was obtalned fram Hoffman La Roche, Basle, Switzerland. The thromb in clotting time was measured by adding $0.05 \mathrm{ml}$ of a thrombin solution $(5-10 \mathrm{~N} \cdot 1 . \mathrm{H} \cdot \mathrm{U} / \mathrm{ml})$ to $0.2 \mathrm{ml}$ plasma after $30^{n}$ preincubation of the plasma at $37 \mathrm{C}$. The clotting time was recorded manually with the Kolle Hook. The fllbrinogenlevel was determined according to the method of Clauss (20) (blological activity) and by rocketimnunoelectrophoresis, using human antlfibrinogen antlbodles purchased from Behrlingwerke, Marburg. FRG. The rocketimmunoelectrophores Is was performed according to Laurell (24). We also estimated the flbrlnogen concentration on pasls of the clotting times obtalned with the snake venom Reptllase (Boehringer Mannhelm, Amsterdam, Holland). Reptllase reagent $(0.1 \mathrm{ml}$, prewarmed) was added to $0.3 \mathrm{ml}$ plasma after preincubation at $37^{\circ} \mathrm{C}$ for 2 minutes. The clotting tilme was manually recorded with the Kolle Hook. Heat defibrlinated samples were prepared according to Hensen and Loell Iger (25) and all so tested for the amount of 1 Ibrinogen related antigen (FRA) by rocket Immunoelectrophoresis.

Flbrin(ogen) degradation products were determined in a conventional assay, using the Thrombo-Wellco test klt (Wellcome Res Lab, Beckenham, England) (senslvity $11 \mathrm{mlt} 10 \mu \mathrm{g} / \mathrm{m} \|$ ) as well as with monoclonal antlbodies agalnst neoantigens which are formed durling proteolytic breakdown of flibrlinogen and flibrlin as descrlbed by Mirshahl (26).

These assays were kilndly performed for us by or. Massoud Mirshahl (Hôtel Dleu, Parls, France). Factor XIII levels were determined in a semiquantltatlive way, using a commerclal test (Boehringer lngelhelm, FRG) according to the manufacturers prescrlption. Crossed Immunoelectrophoresis agalnst human antiflibrinogen antlbodles (antibody concentratlon 0.5 vol\%) was performed according to Laurell (27) in the absence and presence of calclum lactate $(2 \mathrm{mM})$.

Results

In table 2 the data of the coagulation studles of the propositus and the familly are sumarlzed and compared to normal pool plasma and normal values for the age of the proposltus. Fibrin(ogen) degradation products could not be demonstrated in any person of the famlly melther In the conventional assay, using the Thrombo-wellco test kit, (Wellcome Res. Lab, Beckenham, England), nor using a method based on recognition of neoantigens, that are 


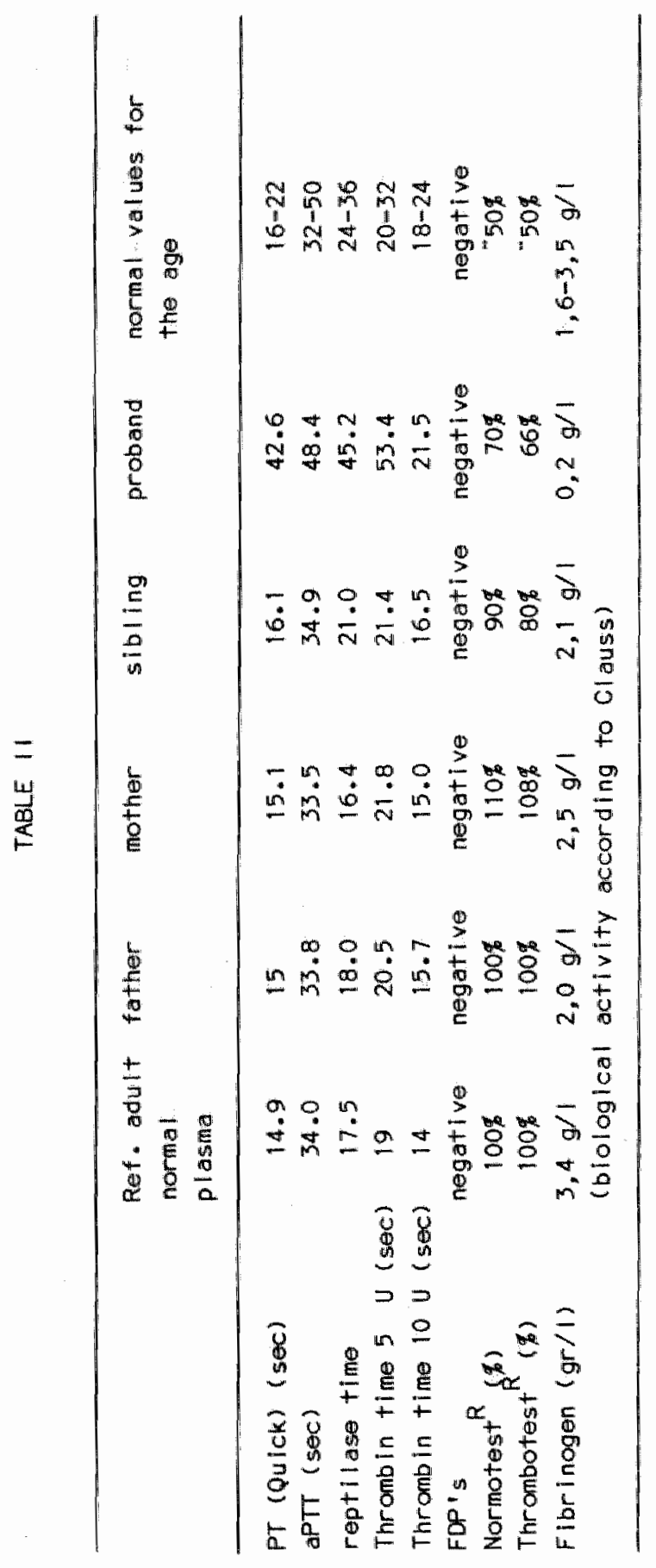


$-119-$

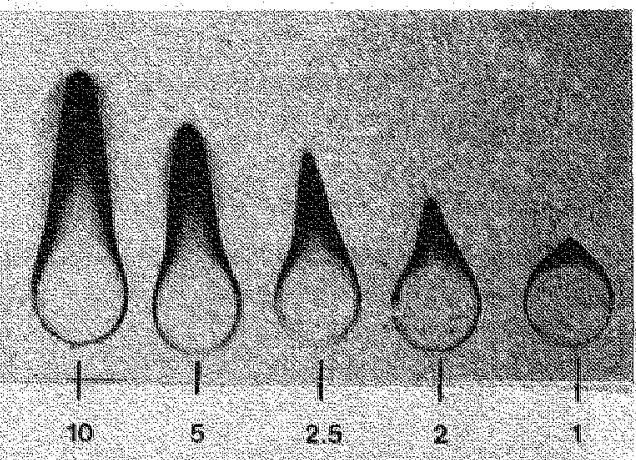

8. PRopositus

- normal plasma

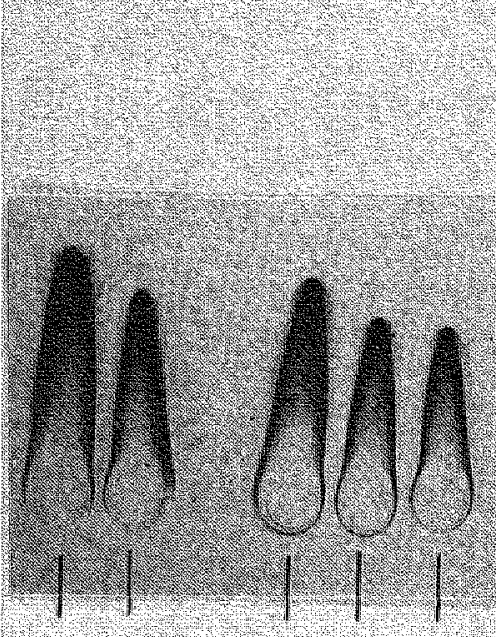

$5 0 \longdiv { 2 5 }$

50

25

20

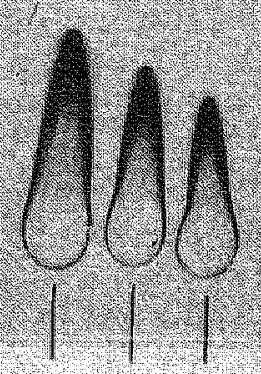

80

25

20

50

25

20

20

60

\%

PLASMA

FIGURE 1

Racketimmunoelectrophoresis of the propositus (upper side) and her faintly and normal plasma against antlfibrinogen antibody.

From left to right: normal plasma, father, mother, sibling, normal plasma 


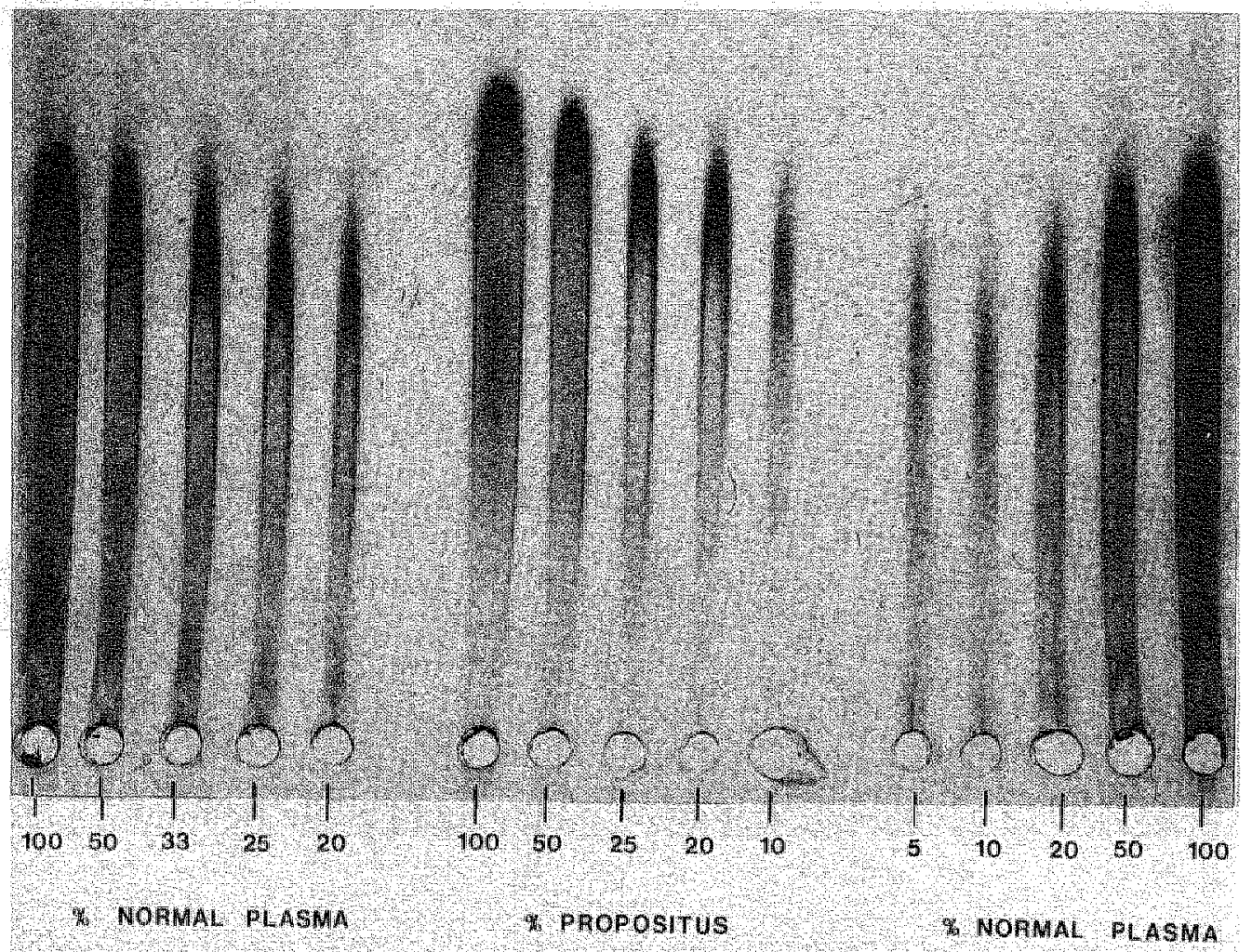

FIGURE 2

Rocket Immunoelectrophores is of heat defibr I nated plasmas 
exposed as the result of proteolytlo breakdown of flbrinogen and or flbrin, by monoclonal antibodies (26). This method detects F.D.P. at levels of 0.25 $\mu_{g} / m l$ and $h l g h e r$. Also in this assay no protoolytlic breakdown products of fibrin or fibrinogen could be demonstrated in the plasma of the propositus and her famlly.

Thrombin clotting times were also measured of mixtures of normal plasma and the patients plasma and the plasma's of the other members of the familly. These data did not provide evidence for a clrculating antlcoagulant cresults not shown). In a number of cases of abnormal flbrlnogens, an Inhllbitory effect on the thrombin clotting time of normal plasma is found (2B). In figure 1 the rocketimmunoelectrophoresis is shown of dilutlons af normal plasma, the propositus and her famlly, using human antllfibrinogen antlbody In a concentration of 0.5 vol\%. The reading was difficult, because in the circumstances used for the electrophoresis, diffusion of flbrinogen related antigen (FRA) was allso seen besldes and under the starting point. The amount of flbrinogen related antigen (FRA) was at least $0.5 \mathrm{~g} / 1$. The ratio of FRA: flbrinogen level according to Clauss was therefore 2.5 or hlgher. in the plasmas of the other members of the famlly no signiflcant discrepancy was noted between the FRA level and the flibrinogen level determl ned according to the method of clauss (results not shown).

in flgure 2 the rocketimmunoelectrophoresis of heat defibrinated plasmas shows that the FRA, estimated according to thls method, appeared to be much hligher than was expected from the results obtained with rocket Immunoelectrophoresls of the non-deflibrinated plasmas. Moreover, we observed a qualitative difference in the precipltation pattern of the propositus, compared to the plasmas of the famllly members and normal plasma.

In figure 3 we show crossed Immunoelectrophoresis patterns of the plasma of the propositus and the family in the absence (panel A) and presence (panel B) of calclum. In the plasma of the propositus an abnormel form and sllightly different position of the preclpitation arc was observed. In the patlent, the factor $x\|l\|$ level was at least 25\%, whlch $\|$ s low normal for her age $(29)$.

In flgure 4, the results are glven of the reptllase clotting times, as a function of dilutions of normal plasma. Based on the flbrinogenconcentration, determined according to the method of Clauss, a reptllase clottling time of around 80 sec. would have been expected. We found, however, a shorter neptllase clotting time in our patlent and estllmated the fibrlinogenconcentration, using the assay, to be around $0.65 \mathrm{gr} / \mathrm{l}$. Reptllase Induced fibrin clot formation in the propositus therefore appeared to be less abnomal, than thromb in Induced flbrin clot formation. 


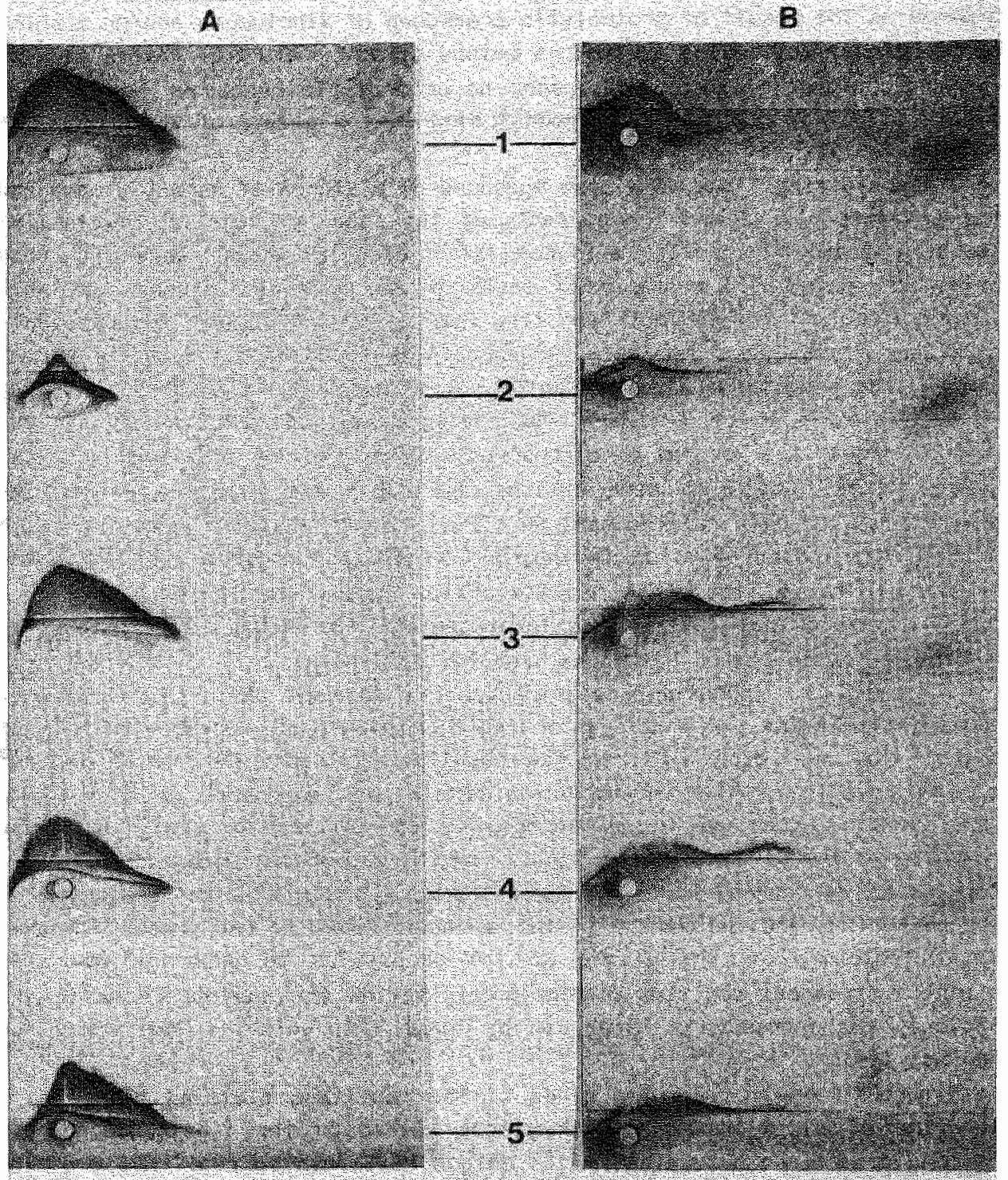

\section{FIGURE 3}

Crossed Immunoellectrophoresis patterns agalnst antlfibrinogen in the absence (pamel $A$ ) and presence (panel B) of calclum lactate (2 mM). 1. normal plasma

2. propositus

3. slbiling

4. father

5. mother 
Reptilase clotting time (sec.)

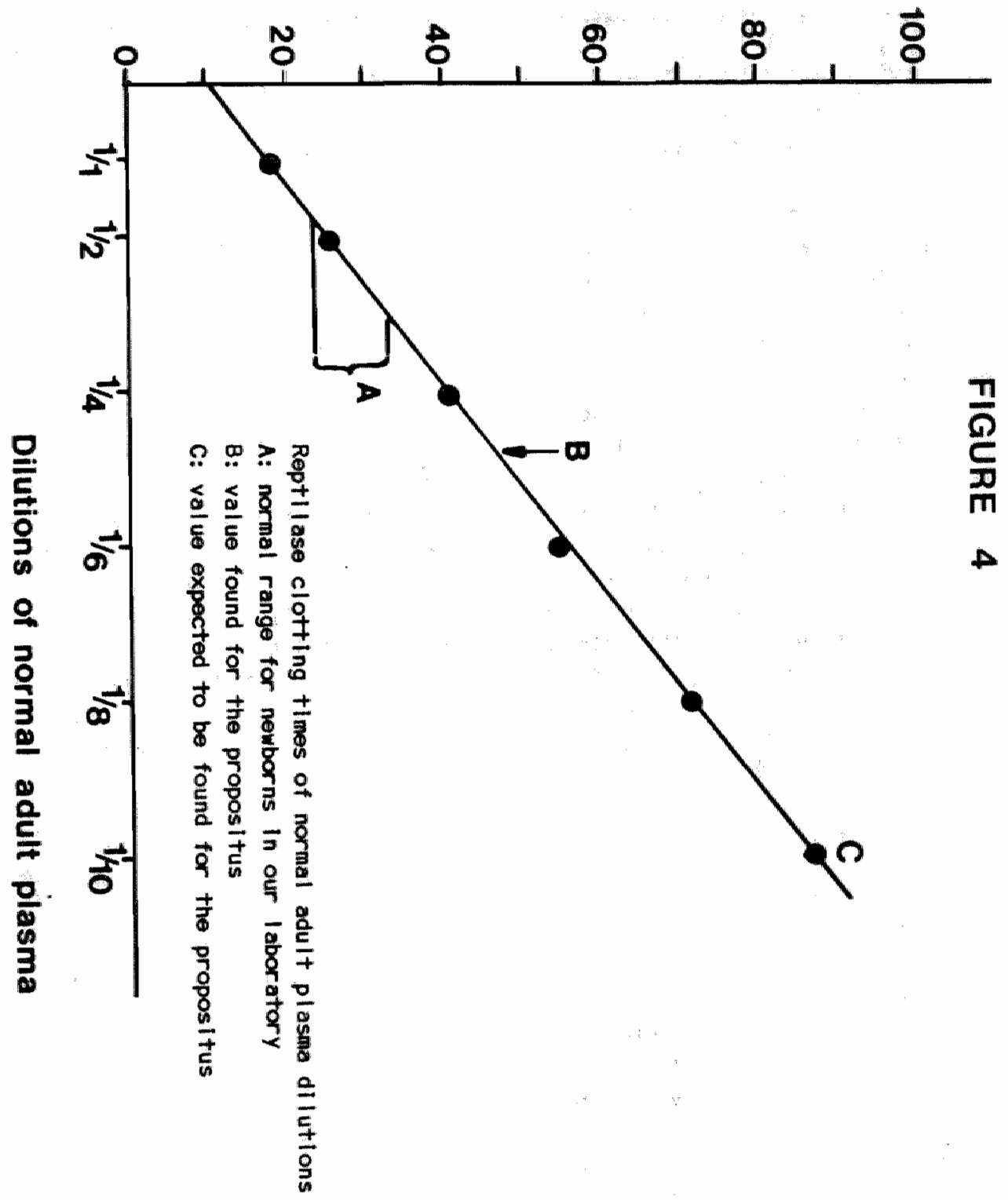




\section{Discussion}

The case described must be consldered to represent a comblned hypodysfibrinogenaemla. The amount of fibrinogen related antigen (FRA) is distinctly hlgher than the anount of clottable fibrinogen. The discrepancy was especlally clear in the "heat deflbrlnated" samples, suggesting that the heating procedure leads to a major change in the antigenlc sltes and a better recognition by the antibody. In our immunolagical studles we found also some evildence for quall itative abnormalitles of the fibrinagenmolecule of the propositus. In the rocketlimmunoelectrophoresis diffusion of FRA was. observed under and besldes the starting polnt. In the rocketimmuncelectrophoresis of the deflorinated pllasma of the propositus the precipltation pattern dlffered from normal plasma. We also found an abnormal precipltation pattern and a slightly different position in the crassed limmunoelectrophoresls of non-defibrinated and deflibrinated plasma of the propositus.

Considering the obvlous advantage of this procedure, it is surprising that only a small number of flbrlnogen varlants have been Investigated by two dimenslomal electrophoresis (28). Another interesting observation was the fact that the reptilase Induced fllbrin cllot formation of plasma of the proposiltus was only slightly retarded, when compared to the thromblin Induced flbrin clot formation. Fibrinlogenl degradation products could not be demonstrated, using the most sensitive methods avallable at the moment. The prolongation of the thrombin and reptllase clotting time in the plasma of the propositus could therefore not be attrlbuted to the presence of flbrin(ogen) degradation praducts. We are aware of the fact, that our data are preliminary. For practlcal reasons (the need of $100 \mathrm{ml}$ plasma) we declded to postpon deflinitive purlflication and characterlzation of the fibrlnogen, the more as there are no practical consequences for our patlent involved. The family hlstory in our case appeared to be negative. This is very unusual, as most of the hypo- and dysflbrlinogenemilas follow a dominant Inherltance pattern. However, in a few famliles a recessive pattern has been postulated.

According to Ménachë (1) only a few cases of a pure hypoflorlnogenaemla have been thoroughly investigated using extensive clottling and "immunologlcal methods. She has postulated, that many cases of hypoflbrinogenaenla are In fact a combined hypo- dysflbrinogenaemila. A nice example of her hypothesis is the family, descrlbed by Hasselback in 1963, as being hypoflibr Inogenaemic, whlch appeared to be a dysfibrinogenaenla (FIbr lnogen Vancouver. Thomas 1968) (31).

Patlents with an aflbrinogenaemia have a bleeding diathesis, especially in the neonatal perlod. The most frequent bleeding site is the umbillcal stump. Thls has also been descrlbed in patients with a severe factor $x / 11$ defliciency. In our patlent the factor $x \mid l l$ level was estimated to be $25 \%$ or more. 
The clinlcal pleture of dystlbrinogenaenla is less unlform than that of congenital aflbrinogenaemla. $60 \%$ is asymptomatlc and is found by chance, when a routl he haemostasis screening is performed. Bleeding problems have been described, but have shown to be severe only for the flbrinogens, Detrollt and Bethesda II:. A predisposition for thrombosis and for Impalred would healing have also been descrlbed. Also the patlents with hypoflbrinogenaem la appear to be heterogeneous with regard to the clinlcal plcture, as well as bloeding as thrombos ls accur (1).

Accordling to Menaché (1) $20 \%$ of the cases of patlents with hypoflbrinogenaemla dle of severe bleeding. In four patlents multiple venous thrombotlc problems w ith pulmonary embollism have been found, 2 of the 4 patlients dled of massive pulmonary emboll $\mathrm{sm}$. It has been postullated that this thrombotic tendency is caused by an altered plasmin Induced proteolysis on an abnormal flibrin surface. Untll now our patlent is asymptomatic and her development was normal.

We have presented thls case, to underline the hypothesis of Menache that many of the hypoflbrinogenaemlas are in fact partly dysflbrinogenaemlas.

Before claiming a new hypo- dysfibrinogenaemla it must be excluded that the molecular defect is the same as in other fibrinogen varlants. TheoreticalIy, It could be the same as descrlbed for flibrinogen Parma (18), fibr Inogen Philladelphla / (32), flbrinogen Valencla (19), fibrlinogen Glessen II (33) and flbrinogen San Juan (32). The hypo- dysflibrinogenaenla descrlbed by Owen (flbrinogen San Juan) was assoclated with van Willebrand disease (34). In our patlent the bleeding time and factor VIIIC activity were normal at birth. Bleeding was often encountered in patlents with these abnormal fibr I nogen molecules $(28)$.

Our preliminary results do not allow us at this moment to conclude that our case can be distingulshed from the above mentloned abnormal ibrinogens. Unfortunately, the data in the 11 terature are also often incomplete, makling a comparlson difflcult or even impossible. We have planned in the near future a definitive purlfication and characterlzatlon of the fibrlinogen of the propositus and her famlly.

\section{References}

1. Ménaché, D. Congenltal flbrinogen abnormallities in: Molecular Blology of fIbrinogen and flbrin (Ed. M.W. Mosesson and R.F. Doollt+le. Annals of the New York Academy of Scliences) Vol 408, 12 (1983)

2. Ménaché, D. Dysflibr I nogenaem la constitutlonel le et famlllale. Proc 9 th Congr. Europ. Soc. Haemat. Lisbon, 1255. S. Karger, Basel/Naw Yark (1963)

3. Corrihons, G., Sorla, J., Sorla, C., Conard, „., Horellou, M.H., Samama, M. Dysfibrlnogénémles congenltales. Sem. Hốp. Parls, 59, 36. 2517 (1983) 
4. Samama, M., Sorla, J., Sorla, C. Congenitall and acquired dysflbrinogenemia. In: Recent Advences In Blood Coagulation, Poller. L., ed. Edinburgh, 2, 313 (1977)

5. Epeberg, D. Inherited flbrlinogen abnormallty causing thrombophllla. Thromb. Hemostas. 17, 176 (1967)

6. Morris, S., Asenniger, M.H., FInlayson, J.S. Ménaché, D. FIbrlinogen Lille: A 7 ASP $\rightarrow$ ASN "Thromb. Haemostas. 46, 104A (1981)

7. Higglins, D.L., Schafer, J.A. Fibrinogen Petoskey, a dysfibrinogenaemla characterlzed by replacement of Arg $A 16$ by a histidyl resldue. J. Blol. Chem. 256, 12013 (1981)

8. Henschen, A., Southan, C., Sorla, J., Sorla, C., Samama, M. Structural abnormallty of flbrinogen Metz and its relatlonship to the clotting defect. Thromb. Haemostas. 46, 103A (1981)

9. Henschen, A., Southan, C., Kehl, M., Lottspelch, F. The structural error and its relation to the malfunction in some abnormal fibrinogens. Thromb. Haemostas 46, 181A (1981)

10. Blombäck, M., Blombäck, B., Mamman, E.F., Prasad, A.S. Flbrlnogen Detrolt: a molecullar defect in the $\mathbb{N}$-terminal disulphide knot of human flbrinogen? Nature 218, 134 (1968)

11. Henschen, A., Lottspellch, F., Southan, S., Töpfer-Petersen, E. Human flbrinogen: sequence, sulfur brlidges, glycosylation and some structural varlants, in: Protides of the Blologlcal Fluids. H. Peeters, Ed. 51 Pergamon Press, New York, NY, (1980)

12. MoDonagh, R.P., Carrell, N.A., Roberts, H.R., Blatt, P.M., McDonagh, J. FIbrlnogen Chapel HIII: hypodysfibrinogenaemia with a tertiary polymerlzation defect. Am. J. Haematology 9, 23 (1980)

13. Rupp, C., Kuyas, C., Häberlle, A., Furlan, M., Beck, E.A. Flibrlnogen Bern 1: a hereditary flbrinogen varlant with defective conformational stabllization by calclum lons. Thromb. Haemostas. 46, 104A (1981)

14. Sorla, J., Sorla, C., Tarorl, S., Samama, M., RImon, A., Tatarsky, J. A new flbrinogen varlant with abnormal gamma chaln: Flbrinogen Halfa, Thromb. Henostas. 46, 359A (1981)

15. Budzynskl, A.Z., Marder, V.J., Ménaché, D., Gull IIn, M.C. Defect In the gammapolypeptide chall of a congenital abnormal fibrlnogen (Paris 1) Nature 252, $66(1974)$

16. Rabe, F., Salomon, E. über Faserstoffmangel Im Blute bel elnem falle von Hämophl |le, Dtsch. Arch. KIIn. Med. 132, 2402 (1920)

17. RIsak, E. Die Flbrimopenle, Ztschr. KIIn. Med. 128, 605 (1935)

18. Imperato, C. D., Dettorl, A.G. I poflibrinogenemla congenilta con flbrinoastenla, Helv. Paediatr. Acta 4, 380 (1958)

19. Aznar, J., Fernandez-Pavon, A., Reganon, E., VIla, V., Orellana, F. Flbrinogen Valencla. A new case of congenital dysfibrinogenaemla. Thromb. Dlath. Heamorrh. 32, 564 (1974)

20. Clauss, A. Gerinnungsphyslologische Schnellmethode zur Bestlimmung des FIbrlnogens. Acta Haemat. 17, 237 (1957) 
21. Quick, A.J. Haemorrhaglic dlseases and thrombosls. 2nd ed. Lea and Fellger, Phlladelphia, (1966)

22. Proctor, R.R. and Rapaport, S.1. The partlal thromboplastin time with kaolin. Am. J. Clin. Path. 36, 212 (196i)

23. Owren, P.A. Thrombotest - a new method for controlling anticoagulant therapy Lancet, II 754 (1959)

24. Laurell, C.B. Quantitative estimation of proteins by electrophoresis in agarose gel containing antlbodies. Analytlcal Blochemistry 15, 45 (1966)

25. Hensen, A., Loeliger, E.A. Antithrombin 111. Thromb. Di ath. Haemorrh. supp I. $10(1963)$

26. Mirshahl, M. Contrlibution a l'étude du fibrlnogène, de la flbrimoformation et de la flibinolyse par l'utllisation d"anticorps monoclonaux, Thesls, Maastrlcht, The Netherlands (1984)

27. Laurell, C.B. Antigen-antlbody crossed electrophoresls. Analytlcal Blachemistry 10,358 (1965)

28. Rupp, C., Beck, E.A. Congentlal dysflbrlmogenaemla. In: Varlants of thuman flbrinogen Ed. E.A. Beck and M. Furlan. p. 95 (1984)

29. Hathaway, W.E., Bonnar, J. Perlnatal coagulatlon. In: Monographs in neonatology, 27-51 New York, Grune and Stratton (1978)

30. Perret, B.A. Electrophoretlic procedures of fIbrlnogen. In: Varlants of human flbrlnogen Ed. E.A. Beck and M. Furlan, pp. 179 (1984)

31. Thonas, J.W.., Beck, E.A.: Congenltal varlants of human fibrinogen. In: Flbrinogen, K. Lakl ed. 269 Morul Dekker, New York (1968)

32. Martinez, J.s Holburn, R.R., Shaplro, S., Erslen, A.J. Flbrlnogen Philadelphla. A hereditary hypodystibrinogenaemia characterlzed by fibrinogen hypercataboll sm. J. Cl ln. Invest. 53,600 (1974)

33. Krause, W.H., Matthlas, F.R., Heene, D.L., Lasch, H.G. Flbrlnogen Glessen 11: A congenital hypodysfibrinogenaemla. Proc. 16. Int. Congr. Hemat. Kyoto, 309 (1976)

34. Owen, C.A., Bowle, E.J.W., Fass, D.N., Perez, R.A., Cole, T.L., Stewart, M. Hypoflbrinogenaemla-dysfIbr I nogenaemla and von WII lebrand's disease in the same famlly. Mayo Cli in. Proc. 54, 375 (1979) 

Injury to the vascular endothellium is normally followed by hamostasls, 1.e. the formation of a so called haemostatic plug. This process requires blood vessel support, adequate numbers and functioning of clrculating blood platelets and sufflclent quantltles of a number of plasma protelns. This complex interaction is counterbalanced by a number of humoral and cellular protective mechanlsms, in order to prevent an excessive reaction which would lead to an impaired bload flow, 1.e., the development of thrombosis. Several key aspects of the haemostatic mechanism in newborn infants are different when compared with adult standards. Quantitative as well as qualltative differences have been descrlbed. Moreaver, haemostatla problems, especlally locallized or generallzed haemorrhages, are often seen In 111 newborn Infants. In splte of the rapld progress that has been made In the last 10 years in understanding the role and function of the varlous components of the haemostatlc mechanlism in adults, our knowledge of the haemostatic mechanism in newborns is still $\|1\| m i t e d$. In this thesls, several aspects of the haemostatlc mechanlsm in newborns are discussed.

Chapter 1 sumnarlzes brlefly our up to date vlew of the haemostatlic mechanlsm in adults. The role of the key enzyme thromb in in the haemostatlc mechanism is especially emphasized. Next, the physlology of the newborn haemostatlc system is revlewed. We have attempted to provide the most current and pertinent data avallable rather than exhausitively to complle the existing literature. In thls chapter, we also discuss whlch mechanlsms can be held responsible for the observation that the thrombin clotting time in newborns is prollonged. In our study, we found that in a small number of the cases $\left(\frac{1}{2}-1 \$ 2\right)$ the inhibition of thrombin in umbllical cord plasma is caused by the presence of a heparin-like substance. We have partlally purlfled this heparin-like substance and described several of 1 ts propertiles. The effect of the hepar $1 n-1 / k e$ substance appeared to be dependent on the presence of antithrombin $\| 11$. The inhibitory effect was abollshed upon incubation with heparlnase, however not upon incubation ith trypsin. In chromogenlc substrate assays, the heparin-like inhlbltor appeared to have a remarkable antl lla (thrombin) effect and hardlly any antl Xa effoct. Until now, circulating heparlin-like substances have only been descrlbed in several haematologlcal malignancles. There were no obvilus differences between the newborns with heparln-like actiwlty in their umbllical cord plasma and those who did not.

All newborns in our study were healthy, full term infants born after an uneventful pregnancy and vaginal dellvery.

Chapter 2 summarlzes the literature on the vitamin $K$ status of mewborns. In the Introduction, we discuss the mode of action of vitamin K. Next, whlch 
mechanlsms can be held responslble for a posslble vitamin $k$ deflclency in newborns. The methods avallable at the moment to dlagnose a vitamin $k$ deflelency are brlefly discussed. Recently, the discussion in the llterature on the $w$ tamili $K$ status of newborns has regalmad much attention. Especlally in the Amerlcian Ilterature, it is propagated that all newborns should recelve vitamin $K$ at blrth prophylactlcally. Based on the data avellable in the IIterature and some own observatlons, we conclude, that the administration of vitamin $K$ at birth to healthy, full term infants is only Indlcated, when the mother is vitamin $k$ deflcient, for instance resulting from fat absorption disturbances, lengthy use of antiblotics and malnutrition. The adminlstration of vitamin $k$ is also indicated, if there are drugs circulating. In the newborn that have an anti-vitamin $k$ effect, such as oral antlcoagulant drugs (coumarin derlvates) or antlconvulsives.

In the postnatal perlod, It may be consldered to supply additional vitamin $K$ orally to breast fed infants. There is an Increasing amount of evidence In the llterature, suggestling that breast fed infants are more at risk for the development of a vitamin $k$ deflclency after blrth, especlally when the vitamin $K$ pool of the mother is marglmal. In The Netherlands this slltuation is probably exceptional.

In Chapter 3 we describe, that the thrombotest, a frequently used screening assay in clinlcal practice, does not give rellable information on the amount of the vitamin $K$-dependent coagulation factors in newborns. For Instance, the correlation coefflclent between the thrombotest clotting times and the prothrombin coagulation activity (IIC) levels is only -0.46 . A moditication and extension of the use of the thrombotest, is the so called thrombotest dillution curve. This curve indlcates the relation between the clotting times obtalned with the thrambotest reagent of several dllutlons of plasma. In curves, obtalned with dillutlions of umbllicall cord plasma, an linhlbitor is found in $67 \%$ of the cases. This inhibitory effect is probably caused by the presence of breakdown products of fibrinogen and flbrin. These products are undetectable in umbllical cord blaod when conventional methods are used. Recently new, much more sensltive methods, based on the use of monoclonal antlbodles, have been developed, which enable us to determine these products directly in plesma. In all samples that showed no inhlbition in thrombotest dllution curves, this test appeared to be negative, whereas it was posltive in inhibltory samples. The most striking was the finding that in these inhibitory samples also florinogen breakdown products were present. We could imitate the inhibitory effect by adding small amounts of purlfled flbrinogen breakdown product fragment $x$ to non-inhlbitory umbilical cord plasma. As ultimate care was taken to prevent proteolysls in vitro, we feel that our data reflect an enhanced fibr ino(geno) Iyt ic state at birth. 
In Chapter 4 describe a study on the synthesls of the coegulation factors 11 (prothrombln) and $V \| I$ in the first 10 days of $\| 1$ fe in newborn calves. At birth these factors ranged from 35 to $64 \%$ compared with adult values, rlsing within 3 days to levels between 70 and $110 \%$. The level of factor VII increased more rapldiy than the level of prothronbin. The administration of abundant vitamin $\mathrm{K}$ for 1 fo 2 weeks before birth gave around the same values, and was not assoclated with a more rapid increase. When phenprocoumon was adminlstered before birth, descarboxy-prothrombin could be demonstrated in the plasma of the newborn calves, indleating that the newborn Ilver is capable of secreting descerboxy-prothrombin and that In this case the capacity of protein synthesis in the liver exceeds that of the carboxylase system, comparable with the situation in patlents on aral ant lcoagulant therapy with coumar in derlvatives. The fact, that the vitamin $k$-dependent coagullation factors at blith are around $50 \%$ of the adult values could partlally be explained by an increased fotal plasma volume before birth (foetus plus placenta), Including an Increased breakdown constant and the normalization of thls volume and breakdown after birth. In thls way, the rapld Increase of the factors after birth could partlally be explalned.

In Chapter 5 we describe a study on the transport of $\left[\right.$ Hivitamin $K_{1}$ over the pllacenta in rats. The concentration of 1 HJvitamin $k_{1}$ Cexpressed in dpm/mg micrasomal protein) in fetal llver was $0.24 \% 3$ hours after adminlstration to the mother, $1.75 \% 24$ hours after adminlstration compared with the values found in maternal 11 ver. This regards the values of hexanelisopropanol extractable radiaactivity, whlch was shown to contaln vitamin $K_{1}$ and no vitamin $K$ degradation products. These results indlcate a malor placental barrler for the transport of vitamin $K_{1}$. In splte of thls low transport, we found no accumulation of endogenous substrate in fetal llver microsomes, whlch is an argument agalnst a functional vltamin $k$ deflciency. Moreover, we could not demonstrate any difference between fetal and adult Ilver mlcrosomes with regard to the accumulation of endogenous substrate upon the adminstration of warfarlin. These results were obtalned, usling IIver microsomes of animals, sacrlifliced 24 hours after the adminlstration of different doses (range $0.05 \mathrm{mg}-7.5 \mathrm{mg}$ per anlimal) of warfar in. The carboxylase activitles of adult and fetal rat I lver mlcrosomes were comparable, indicating that the newborn rat has an adequate carboxylating system.

In Chapter 6 a new method is descrlbed for the determination of the amount of vitamin $K$ in liver tissue. Thls method is based on the blalaglcal activity of vitamin $K$, present in Ilver +1 issue, in the incorporation of $\mathrm{CO}_{2}$ into an exogenous substrate (F LE E L). In adult rat and cow liver microsones the amount of endogenous vitamin $k$ was in the range of $1.6-4$ $\mathrm{ng} / \mathrm{mg}$ mllcrosomal protein. In a pllot experlment we found distinctiy lower levels (50\%) in fetal rat Ilver mlerosomes. 
In Chapter 7 wescrlbe the reevalutalon of the so called fetal fibrinogen. Almost all propertles, that have been ascribed in the llterature to a distlnct fetal flibrinogen In man, appeared to be due to contaminatlan of the $f i b r i n o g e n$ preparations ith flbrincogenl degradation products, probably as consequence of inadequate purlfication procedures. In this study, we purified umblllcal cord flbilnogen under conditions which minlmize proteolytlic breakdown in vitro. We could find no differences between cord and adult flbrlnogen with regard to the effects of $\mathrm{pH}$ and lonlc strength on Its clatting properties, the $\mathrm{K}_{\mathrm{m}}$ for thromb in, SDS polyacrylamlde gelelectrophoresis behaviour or carbohydrate content. However. the phosphorus content of cord flibrnogen was 3-4 times higher than that of adult fibrinogen. The accelerating effect of calclum on the thrombin clotting time was more pronounced in newborn cord plasma and purlfled cord flbrlmogen preparatlons as compared with adults. This might be explalmed by the migher phosphorus content of the cord fllor Inogen molecule.

In Chapter 8 descr lbe a new case of a comblned hypo-dysflibrinogenaemlla. 
Haemostase is het proces, dat leldt tot het tot staan komen van een bloeding na een vaatwandbeschadigling. Hlerblj wordt een zogenaamde haemostatische prop gevormd. Dit proces komt tot stand wil complexe interactles tussen de vaatwand, bloedplaatjes en een aantal plasmaelwitten. Tenelnde een overmatige reactle to voorkomen, die zou lelden tot oen belemmer Ing van de normale bloedstroom, c.q. het ontstaan van thrombose, beschlkt het llichaam over en aantal verdedigingsmechanismen, dle op gerlcht zlJn de vorming van een haemostatische prop te beperken tot de plaats van de vaatwandbeschadliging. De haemostasereactie blj pasgeborenen verschllt in en aantal opzichten zowel kwallitatief als kwantitatlef van die blj de volwassenen. Haemostase problemen komen ook rellatlef vaak voor blj zlieke pasgeborenen. Ondanks de explosleve toename in de laatste 10 Jaar van onze kennls wat betreft de verschlllende componenten van de haemostasereactle bij volwassenen, bestaan or nog tal van controverslïlle punten wat betreft de haemostasereactle bij pasgeborenen. In dit proefschrift worden een aantal aspekten van de haenostasereactio van pasgeborenen besproken.

Hoofdstuk 1 geeft een beknopt overzlcht van de huldige stand van kennis wat betreft de haemostasereactie blj volwassenen, warbij met name aandacht wordt besteed aan de centrale rol, die het enzym thrombine hierblj speelt. Vervolgens wordt een literatuuroverzlcht gegeven van wat er thans bekend is over de haemostasereactle b.lj pasgeborenen. De verschlllende componenten worden systematisch besproken. In dit hoofdstuk wordt ook Ingegaan op de vraag op welke mechanismen de verlengde thromblnetljd van pasgeborenen kan berusten. In ons onderzoek hebben we gevonden dat In een klein aantal gevallen $\left(\frac{1}{2}-1 \% 2\right)$ de reming van thromblne in navelstrengplasma wor dt varoorzaakt door een heparlneachtige stof. We zijn er In geslaagd een partiele zulvering to doen en enkele elgenschappen van deze remmer to onderzoeken. Het effekt van de hepar ineachtlige stof was afthankelljk van de aanwezlgheld van antithrombine 111 , het effekt werd tenlet gedaan na incubatio met heparlnase, echter nlet na incubatle met trypsine. De heparl neachtige stof bleek In assays, gebaseerd op het gebrulk van chromogene substraten, on ultgesproken antl lla (thromblne) effekt te hebben, echter vrlJwel geen antl Xa effekt. Tot nog toe waren clrculerende heparlmeachtige stoffen blj de mens alleen beschreven bIJ bepalde haenatologlsche mallgniteliten. De pasgeborenen, bll wie we deze hepar Ineachtlge stof gevonden hebben, verschllden qua zwangerschapsduur, partus en verdere beloop nlet dulldelljk van de andere door ons onderzochte pasgeborenen. Het betrof in alle gevallen gezonde pasgeborenen, die à terme vaginaal, op eon normale wijze na oem normal verllopen $\mathrm{zwangerschap} \mathrm{geboren} \mathrm{werden.}$ 
Hoofstuk 2 geeft en llteratuuroverzlcht over de vitamine $k$ status blj pasgeborenen. In de inlelding wordt het werkingsmechanisme van vitamine $k$ besproken. Vervolgens, welke mechanlsmen ten grondslag kunnen liggen aan een mogelljke vitamlne $k$ deflclëntle blj pasgeborenen. De discussle hlerover In de lliteratuur is de laatste Jaren weer opgeleefd. Na ben bespreking van de op dit moment tot onze beschlikking staande methodieken an een vitamine $\mathrm{K}$ deflclëntle te dlagnostl seren, wordt samengevat wat thans bekend Is over de vltamine $K$ status blj pasgeborenen. In met name de Amerlkaanse llteratuur wordt gepropageerd om aan alle pasgeborenen bil de geboorte profylactisch vitamine $K$ toe to dlenen. Op basis van de literatuur en enkele elgen waarnemingen komen we tot de conclusle, dat het toedlenen van vitamilne $K$ blj de geboorte aan gezonde, voldragen pasgeborenen, alleen zinvol is Indlen ar sprake is van een vitamine K-deficlëentie blj de moeder (b.v. vetresorptlestoornlssen, langdurig gebrulk van breedspectrum antlblotlca of voedingsdeflclëntles). Vitamine $K$ toedlening is ook geindlceerd, Indlen er blj de pasgeborene geneesmiddelen circuleren, dle oen antlvitam Ine $\mathrm{K}$ werkling hebben zoals oralle anticoagulantla (coumar ine der ivaten) en anticonvulsiva.

In de postnatale perlode valt te overwegen om kinderen, die ultsluitend borstvoeding kil gen extra witamlne $K$ oraal te geven. In de llteratuur zijn voldoende argumenten aanwezlg, dle het aannemelljk maken, dat deze kInderen een verhoogde kans hebben om na de geboorte een vitamine $K$-deflclëntle te ontwlkkelen, met name wanneer de vitamine $K$ reserve blj de moeder marglnaal is. In Nederland is oen dergelijke situatle echter als ultzonderlijk te beschouwen.

In hoofdstuk 3 wordt beschreven, dat de thrombotest, en veel gebrulkte screeningstest in de dagelljkse praktijk, geen betrouwbare informatle geeft over het gehalte an vitamine $k$ afhankel ljke factoren bij pasgeborenen. De correlatlecoëflclent tussen de thrombotesttljd en het factor llc (prothrombine) gehalte is bljwoorbeeld slechts -0.46 . Een modiflcatie en ultbrelding van de thrombotest is de zogenaamde thrombotestverdunningscurve. Deze curve geeft het verband aan tussen de stoltijden bepaalid met het thrombotestreagens en de daarvoor gebruikte plasmaverdunningen. In 67\% van de gevallen wordt in thrombotestverdunningscurven wan navellstrengp lasma een remmer gevonden. WIJ maken het waarschijnllijk, dat deze remming wordt veroorzaakt door afbraakprodukten van flbrinogeen en flibrine. Deze afbraakprodiukten zllJn met de conventionele methoden nlet aantoonbaar in navelstrengbloed. Recent ziJn nleuwe, veel gevoellger methoden lop basls van monoclonale antillchamen) ontwikkelld, waarmee deze produkten direct in plasma kumnen worden aangetoond. Deze test bleek negatief in alle samples war geen reming in de thrombotestverdunningscurve werd gevonden en positlaf in de remmende navelstrengplasma's. Het meest opmerkell Jk was de bevinding, dat in deze gevallen cok flbrlnogeenafbraakprodukten werden gevonden. Het remmende effekt kon worden geimlteerd, door kleine hoeveel- 
heden van gezulverd flbrinogeen afbraekprodukt fragment $X$ toe to voegen aan nlet remend inavelstrengp lasma.

In Hoofdstuk 4 wordt een onderzoek beschreven naar de synthese van factor II (prothromblne) on factor VII in de eerste 10 diagen na de geboorte blj kalveren. Bilj de geboorte lag de range van deze factoren tussen de 35 en 64\%, binnen drle dagen stljgend tot warden tussen de 70 en $110 \%$. Het factor VII gehalte steeg daarbil sneller dan het prothrombinegahalte. Het toedienen van grote hoeveelheden vitamine $K$ gedurende 1 a 2 weken voor do geboorte gaf geen andere waarden en gling ook nlet gepaard met en snellere stljging van deze factoren. Wanneer phenprocoumon voor de goboorte werd toegedlend, kon descarboxyfactor 11 worden aangetoond, aangevend dat do foetale lever in staat is on descarboxy-factor: 11 ut to schelden on dat in dit geval de elwitsynthese an slch normaal verloopt, terwljl de carboxylering onvoldoende is, en sltuatle vergelljkbaar met die blj mensen dle orale anticoagulantia (coumar Ine der Ivaten) gebrulken.

Het feit, dat de witamine $K$ afhankel IJke factoren bij de geboorte gemiddelld 50\% van de volwassen warden zlJn, zou mede kunnen worden verklaard door een toegenomen foetaal plasma volume voor de geboorte (foetus plus placenta) met een bljbehorende grotere afbraakconstante en een normallzeiling van dit volume en de afbraak na de geboorte. Op deze wijze zou teen gedeelte van) de toename van de factoren na de geboorte verklaard kunnen worden.

In Hoofstuk 5 wordt het transport van [ HIvitamine $K_{1}$ over de placenta bi] ratten beschreven. Ultgedrukt per mi microsomaal ellult in de lever is de concentratle van [ H]vitamine $K_{1}$ bl] de foetus 3 uur na toedlening aan de moeder $0.24 \%, 24$ uur na toedlening $1.75 \%$ ten opzlchte van de warden gevonden in moederlever. Het betreft hier de hexaanlsopropanol axtraheerbare radloactivitelt. In deze fractles bevinden zlch geen vitamine $k$ afbraakprodukten, doch ultslultend witamine $k$. Ondanks deze barrlère, vonden wilj in foetaal leverwefsel geen accumulatle van endogeen substraat, hetgeen plelit tegen een functionele viltamine $K$ deflciëntie.

Bovendien vonden wlJ geen verschllien tussen foetale en volwassen rattonlevers ten aanzien van de accumullatlo van endogeen substraat na toedienling van verschlllende doses warfarine. Deze bepallingen werden verrlcht 24 uur na toedlening van de warfarlne. De carboxylase activiteit van volwassen en foetale rattenlever microsomen was vergellukbaar, aangevend dat de pasger boren rat over en adequat carboxyler Ingssyteem beschlkt.

In Hoofdstuk 6 wordt een nleume methode beschreven on het vitamine $k$ gehalte lin leverweefsel te bepalen. De methode is gebaseerd op de biologlsche activitelt van deze zgn. endogeen aanwezlge vitamline $K$. BIj volwassen ratten en koelen vonden wlJ en vitamline $K$ gehalte van $1.6-4 \mathrm{ng} / \mathrm{mg}$ mlcrosomal elwit. BlJ pasgeboren ratten werden waarden gevonden rond $50 \%$ van de waarden gevonden bllj volwassen ratten. 
In Hoofdstuk 7 wordt het zogenaande foetalle flbrinogeen beschreven. Vrijwel alle elgenschappen die in het verleden aan een apart "foetaal" fibrinogeen blj de mens werden toegeschreven bleken te berusten op contaminatle van de flbr Inogeenpreparaten met flbrinlogeenlafbraakprodukten als gevolg van onzorgvuldige zulveringstachnleken. In deze studle hebben wij navalstrengfibrinogeen gezulverd onder conditles, die in vitro proteolyse tot een minlmum beperken. WIJ konden geen verschil vinden tussen navelstreng en volwassen flibrlnogeen wat betreft het effekt van $\mathrm{pH}$ en lonsterkte op de stolbaarheld, de $K_{\mathrm{m}}$ voor thrombine, SDS polyacryl amlde gelelectrophorese en het gehalte aan koolhydraten. Het enige verschll bleek een 3 à 4 mal hoger fosfaatgehalte, warvan de betekenls vooralsnog onduldelijk is.

In Hoofdstuk 8 wordt en nleuw geval beschreven van een patlënt met een gecomb I neerde hypo- en dysflbrinogenaemie. 
Dit proefschrift kwam tot stand in het blochemlsch laboratorlum van de Rljksunlversiteit Llmburg onder lelding van mljn promotor Prof. Dr. H.C. Henker.

Coen, mlJn dark gaat in de eerste plaats ult naar jou voor al je hulp on steun in de afgellopen $\rfloor$ aren.

Mijn co-promotor Dr. C. Vermeer ben lk ook veel dank verschuldigd voor al zijn inzet, grote belangstelling en vermogen tot stimularen.

Cees, de hulp van Jou en de medewerkers van Jouw groep heb $1 k$ alt ljd zeer op prlJs gesteld. In dit verband wil ik met name Berry Soute en Marlanne de Boer danken met we lk 'n gedeelte van de in dlt proefschrlft beschreven experimenten heb uitgevoerd.

Een bljzondere plaats in dit nawoord verdlent Paul Dévllée.

Paul, we hebben langdurlg plezlerlg samengewerkt in de afgelopen Jaren. Ondanks de inlndernlssen en frustratles dle we daarblj soms onderweg tegenkwamen, blieef je altljd vrlendelljk, positlef en bovenal bemoedigend, hetgeen ultelndelljk oen belangr IJke bljdrage heeft geleverd blj het tot stand komen van dit proefschrlft. Ik ben je hler bljzonder erkentelljk woor.

Dok veel dank ben lk verschuldigd aan Puck Muller.

Puck, lk heb cok met joul in de afgelopen perlode altijd fljn samengewerkt, met name wat de betreft de laboratorlumdlagnostliek van patlënten met haamostase en tromboseproblemen. In dit proefschrlft is dat tot uiting gekomen in de beschrljulng van een patiente met en aangeboren hypodys flibr linogenemle.

De referenten, Prof. Dr. J.A. Flendrig. Prof. Dr. E.A. Laeliger en Prof. Dr. M. Samama, wll ik hartelljk danken voor hun stlmulerende en constructleve bljdragen, hetgeen zonder meer de kwalltelt van het proefschrlft ten goede is gekonen.

In miJn dank wil ik cok graag betrekken de Vroedvrouwenschool te Heerlen (Indertlijd hoofd: wljlen Dr. R. Oomers) on de afdelling obstetrle en gynaecologle van Zlekenhuls Annadal te Maastrlcht (hoofd Prof. Dr. J. de Haan). Ik wil belde afdellingen bljzonder danken voor de bereldwlligheld en ondersteunling wat betreft het verkrljgen van een deell van het materlaal, dat gebrulkt werd voor dit proefschrlift.

De dlenst centrale proefdiervoorzlenlngen will lk ook graag danken voor de steeds plezlerlge en adequate ondersteuning wat betreft hat dlerexperimentele gedeelte. In het bljzonder gat mijn dank hierblj ult naar Frans Weekers.

Het vele type-werk en de uiltelndelijke productio en lay-out van het proefschrift is op voortreffelljke Wijze verzorgd door Mariet Molenaar-v.d. Voort.

Marlet, jouw tomelloze energle en inzet wat dit betreft heb lk bljzonder gewaardeerd.

Guus van Rooy van de audiovisuelle dienst verzorgde het copy proof maken van 
de flguren en het fotomaterlaal en Ben Meerstadt verzorgde de druk van het proefschrlft. Dok hen belden wll ik hartelljk danken.

Last, but not least, wll ik Hans danken, voor al haar begrlp en hulp in de afgelopen per lode.

Hans, Je hebt er voor gezorgd dat ik in alle rust ontspannen thuls kon werken, een bljdrage dle lk besllst nlet onderschat en warwoor veel dank. 


\section{Currlculum Vitae}

De schrljver van dit proefschrift werd geboren op 26 augustus 1948 to "s-Gravenhage. HlJ behaalde het Gymnaslum B diplona in 1966 aan het Aloysluscol lege te "s-Gravenhage.

In dat jaar begon hil de medische studie aan de Rijksuniversitelt te Lelden. Het doctoraal examen werd behaald in december 1971, het artsexamen In aprll 1974. In jull 1974 begon hlJ zljn oplelding tot internlst aan de Interne afdeling van het milltair hospltaal te Utrecht CDr. C.J. van Belle en Dr. M. van Zoeren). De oplelding word vanaf Jull 1975 gecontinueerd aan de interne afdeling van het gemeentezlekenhuls Leyenburg te "s-Gravenhage (oplelder Dr. P.S. Blom). In deze perlode werden stages gelopen op de afdeling cardlologle (Dr. C.M. Sparling) en de afdeling haematologlo (Dr. C.H.M. Leeksma).

In Jull 1979 werd hlj ingeschreven als internlst in het speclallsten register. Vanaf september 1979 is hilj werkzaam blj de Rljksuniversitelt Llmburg blj de capaclteltsgroep Blochemie (Prof. Dr. H.C. Hemker, Prof. Dr. R.F.A. Zwaal) en de werkgroep haematologle-oncologle (Dr. G.H. BI UJ ham) van de afdelling Interne Geneeskunde (hoofd: Prof. Dr. J.A. Flendrlg) van Zlekenhuis St. Annadal te Maastrlcht. HIJ is waarnemend hoofd van de sectle haemostase en thrombose onderzoek van het Haenatologlsch laboratorlum van net Zlekemhulls St. Annadal te Mastricht. 